\title{
Contributions to Mineralogy and Petrology
}

\section{Fe3+ partitioning systematics between orthopyroxene and garnet in mantle peridotite xenoliths and implications for thermobarometry of oxidized and reduced mantle rocks --Manuscript Draft--}

Manuscript Number:

Full Title:

Article Type:

Keywords:

Corresponding Author:

Corresponding Author Secondary

Information:

Corresponding Author's Institution:

Università di Padova

Corresponding Author's Secondary

Institution:

First Author:

Paolo Nimis

First Author Secondary Information:

Order of Authors:

Paolo Nimis

Alexey Goncharov

Dmitri A. Ionov

Catherine McCammon

Order of Authors Secondary Information:

\begin{tabular}{|c|c|}
\hline Abstract: & 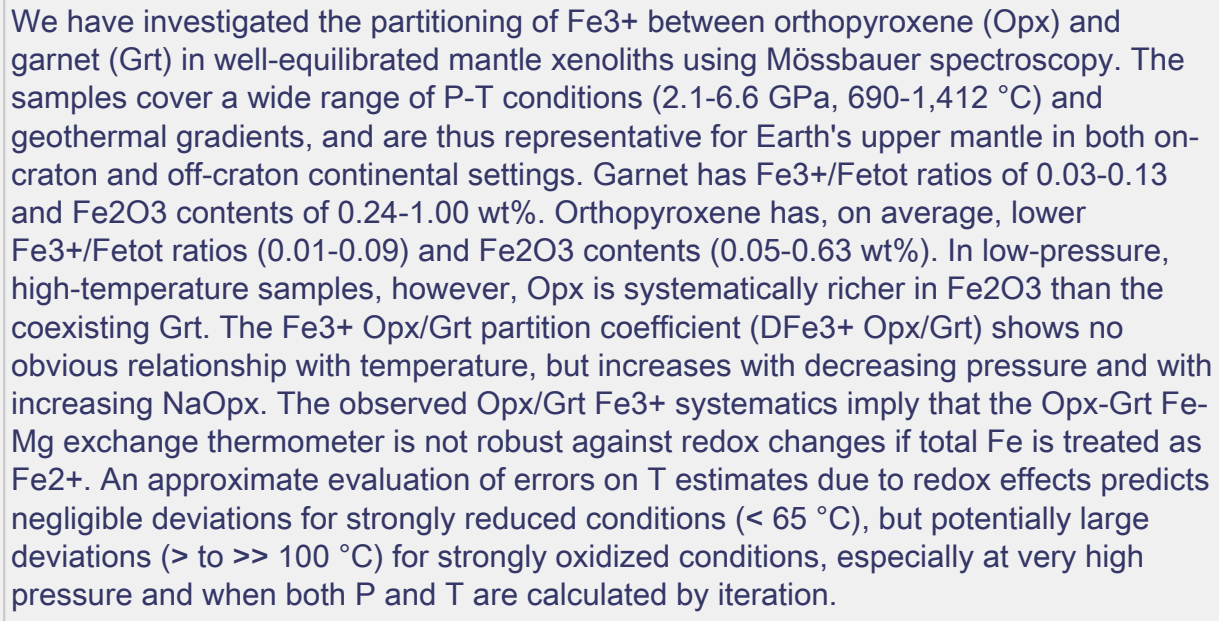 \\
\hline Response to Reviewers: & $\begin{array}{l}\text { Our replies to the Reviewers' specific comments are listed here and introduced by the } \\
\text { notation "R -". } \\
\text { Reviewer \#1 } \\
\text { I) The role of clinopyroxene } \\
\text { Among mantle minerals clinopyroxene should not be neglected since it is the phase } \\
\text { that most incorporates Fe3+ among mantle minerals... } \\
\text { R - We have added Mössbauer data for Cpx in nine of our xenoliths (the others were } \\
\text { either two small-sized or contained too little Cpx to obtain sufficient separates). The } \\
\text { results are now briefly described in the "Mössbauer analysis" section, presented in new } \\
\text { Table 5, and discussed in the "Results" section. Since the aim of the paper is }\end{array}$ \\
\hline
\end{tabular}


investigating Opx-Grt relationships, only the aspects that may have some bearing on the incorporation of $\mathrm{Fe} 3+$ in $\mathrm{Opx}$ and Grt are discussed in detail.

As an example some confusion arises at P. 12, L. 1-13, where the authors wrote that "the $\mathrm{Fe} 3+$ opx/grt partition coefficient shows no relationship with $\mathrm{T}$ and a roughly negative correlation with $\mathrm{P}$... in contrast with data of clinopyroxene-garnet pairs..." This comparison is useless without considering all the phases that may incorporate $\mathrm{Fe} 3+$ at equilibrium.

R - We have added a two-plot Figure (now Fig. 5a,b) which summarizes the Fe3+ partitioning behavior of $\mathrm{Cpx}$ vs. Grt and Opx.

Why Iherzolites sample from Dariganga are the only ones with InDFe3+(opx/grt) $>0$ (Fig. 3), whereas harzburgites not?

$R$ - The Dariganga xenoliths are not the only ones with significant modal abundances of Cpx. To avoid confusion, we have added a new Table (now Table 1) with main petrographic and compositional features of our xenoliths and clarified the text where needed. Clearly, the abundance of Cpx cannot account for the systematic displacement of the off-craton Dariganga samples from the on-craton samples in terms of $\mathrm{Opx} / \mathrm{Grt} \mathrm{Fe} 3+$ distribution.

II) Redox conditions versus oxygen fugacity

...l profit to make a general comment that might go beyond the goal of this work...

...Tens of works use to claim that oxygen fugacity decreases with pressure when compared with FMQ buffer, due to stabilisation of the skiagite component in garnet...

...the habit to compare fO2 with $\mathrm{FMQ}$ buffer... is trivial... because $\mathrm{FMQ}$ buffer will never occur in peridotite rocks [and]...the commonly used equilibrium skiagite $=$ fayalite + ferrosilite + O2 of Gudmundsson and Wood (1995), which involves only Fe-bearing phases, shows a slight negative slope with pressure while FMQ has a positive slope... $\mathrm{R}$ - As admitted by the reviewer, these interesting aspects go beyond the goal of the present work, as our aim is not to revisit redox estimates for mantle peridotites. We only use the available estimates to bracket the redox conditions expected to be relevant for lithospheric mantle sections, and the same method used to estimate the redox conditions (Stagno et al. 2013) is used backward to calculate model Fe3+/Fetot ratios in Grt. Ours is a 'relative' approach (see Appendix for details) and thus the effect of possible systematic inaccuracy in fO2 estimates is minimal.

It must be said that Gudmundsson and Wood themselves specified that the Fe3+/Fetot in orthopyroxenes of upper mantle composition can be neglected in the calculation of FeSiO3 activity only if this is less than 0.05 (Page 64 of the cited work)... This point should be stressed in the manuscript in order to strengthen the importance of considering the $\mathrm{Fe} 3+$ content in orthopyroxene, which seems to be above $5 \%$ in many mantle peridotites, as a further variable in the calculation (I would say estimate) of fO2 in these systems.

R - Gudmundsson and Wood (1995) stated something different. The correct quotation is "Mössbauer data (Dyar et al. 1989; Wood, unpublished) show that the Fe3+/SFe of orthopyroxenes of upper mantle composition is only about 0.05 , an amount which can be neglected in the calculation of $\mathrm{FeSiO} 3$ activity." However, the suggestion of including a discussion of the potential implications of our data on $\mathrm{fO} 2$ calculations is valuable. We have added a paragraph in the "Conclusions" section. It appears that even if some of our Opx are richer in Fe3+ than commonly assumed, the bias on redox calculations should still be negligible.

Minor comments:

P. 3, L. 6-11: The citation of Frost and McCammon 2008 about "distribution of ferric iron in mantle minerals" is not appropriate (see comment I). In this work the authors reviewed the various oxybarometers referring only to the Fe3+ content in spinel, garnet, perovskite, etc. in the use of redox equilibria involving one Fe3+-bearing phases.

R - Ok, deleted.

P. 3, L. 13-30: It should be specified that here only the subcratonic mantle is considered here as "upper mantle sections", otherwise other works should be cited for oceanic mantle and supra-subduction mantle. 
R - Ok, text changed.

P. 7-8: relative to Mossbauer analyses, given the accuracy of the data reported, it should be useful write a sentence to demonstrate the absence of possible exsolutions of magnetite in orthopyroxene which is not rare in this kind of rocks, in order to exclude that the Mossbauer analyses (bulk) also include magnetite in the Fe3+ measurements. $\mathrm{R}$ - Ok, sentence added justifying the absence of exsolutions.

P. 15, L.15: "the following expression ... as a function of $\mathrm{P}$ and $\mathrm{Na2O}$ (Fig. 4). I do not understand the link between this statement and Figure 4 . Is the reference wrong and related to Figure $3 c$ ? Otherwise this should be better explained.

$\mathrm{R}$ - Ok, text clarified.

P. 16, L. 11-20: I do not completely agree with this section, unless clinopyroxene is absent in the association, as well as the statement at 26-28 that "opx may represent the most important Fe3+ carrier in the mantle" (see comment I).

A more complete discussion of this issue is now provided, considering the modal proportions of minerals, crystalchemical considerations on Opx, and the new Cpx Fe3+ data.

$\mathrm{R}$ - We still maintain that opx may represent one of the most important Fe3+ carriers in Earth's lithospheric mantle, if the larger contribution of off-craton mantle sections is considered. Indeed, in our Dariganga samples, Opx IS the most important Fe3+ carrier!

P. 17, L. 18: "then temperature estimates may be affected by changes in redox conditions", redox conditions of the orthopyroxene (see comment II).

$\mathrm{R}$ - See reply to comment II.

P. 23, L. 22-24: as far as I know, Stagno et al. (2013) only consider the Cr-bearing garnet end-member in the reciprocal reactions used to calculate activity coefficients, but the equilibrium they propose to be used in the calculation of fO2 (their equilibrium 3 calculated using their equation 6) $\mathrm{Cr}$ is not considered in the exchange equilibrium between grossular and andradite. Their oxybarometer is not sensitive to the $\mathrm{Al}$ and $\mathrm{Cr}$ contents in garnet.

$\mathrm{R}$ - Since the activities are used in $\mathrm{fO} 2$ calculations, the oxybarometer is sensitive also to $\mathrm{Cr}$ and Al. We have clarified this point in the text.

Reviewer \#2: General comments

My major complaint with this paper is that it is truly a shame that the authors did not also measure the $\mathrm{Fe} 3+/ \mathrm{Fe} 2+$ for the clinopyroxenes in their samples - that would have been invaluable, and I hope the authors plan to do so in future.

$\mathrm{R}$ - Cpx data for nine samples were added and their relationships with Grt and Opx were discussed.

Specific comments

Page 6, line 33: Doucet et al (2013) missing from reference list

R - Ok, added.

Page 8, lines 18-20: More information on the "special holder to avoid asymmetry of the spectra" would be very helpful, especially in light of the later comment suggesting preferred orientation was a problem in the Canil and O'Neill study (page 9, lines 4043).

$\mathrm{R}$ - Ok, text changed.

In general, more information on the fitting of the orthopyroxene spectra would be good - there is no way for the reader to judge whether the hyperfine parameters determined in this study compare well or poorly to previous work, or to get any indication of whether the authors are interpreting the ferric iron to be in tetrahedral or octahedral coordination.

$\mathrm{R}$ - Ok, more detailed fitting approach added in the "Mössbauer analysis" section and sentence added that ferric iron is octahedral.

Page 9. Line 1: Woodland and Ross (1994) missing from reference list. 
R - Ok, added.

If the Fe3+/SigmaFe (Corrected) values in Table 3 are the result of applying this model for the recoil-free fractions in garnet, it would be good to note that in a footnote to the table.

R - Ok, done.

It would also be of interest to see how much this correction shifts the fO2 calculated with the Stagno et al. oxybarometer, given the $\sim 25 \%$ reduction in the calculated Fe3+/SigmaFe.

$\mathrm{R}$ - A sentence was added in the Appendix.

Page 12, line 49 - are the hyperfine parameters observed consistent with this assumption (or the one on page 14 about tetrahedral coordination)?

$\mathrm{R}$ - Ferric iron in Opx is essentially octahedral according to hyperfine parameters and we added a sentence stating this. However, the possibility that undetectable amounts of $\mathrm{Fe} 3+$ also enter the thetrahedral site cannot be excluded. We have emphasized in the text that these amounts, if any, should be minor.

Late Reviewer \#3

A) Considering that the measurement of Fe3+ in opx forms the basis for this manuscript, it is important that the approach for fitting the opx spectra is adequately discussed. The fitting strategy is presented on p. 8 without any real discussion of existing literature, for example, Luth \& Canil (1993), Canil \& O'Neill (1996) and Woodland et al. (2006). For example, an apparent asymmetry in a spectrum can be caused by different factors. Preferred orientation can indeed be a cause, as mentioned in the text. The authors indicate that their samples were specially prepared to avoid such effects, but they don't explain what was so special about their method. However, spectral asymmetry can arise from other effects such as nextnearestneighbor effects. In fact this was invoked for garnet, but apparently the authors do no accept this possibility for opx, even though such effects have been described for $c p x$ and opx since the 1970's.

$\mathrm{R}$ - More detailed fitting approach added in the "Mössbauer analysis" section.

The errors provided in the data table are only those related to the fitting process and do not capture the true sum of errors. Errors for opx are usually considered to be about \pm 0.01 , but are potentially higher for opx, due to peak overlap and the relatively small contribution from $\mathrm{Fe} 3+$. Catherine McCammon can provide more information about this aspect.

$\mathrm{R}$ - This is correct; hence we used only two doublets for Fe2+ where peak overlap is minimized. Errors for opx would be higher in the case of fixing parameters of the Fe3+ doublet, as was done in Canil \& O'Neill (1996).

What are the uncertainties in the hyperfine parameters? Too many decimals are reported in the Mössbauer data tables.

$\mathrm{R}$ - Ok, Tables changed accordingly.

It is claimed without any explanation that opx in a sample from Canil \& O'Neill (that was refit for this study) contained $8 \% \mathrm{cpx}$ contamination. Considering that opx and $\mathrm{cpx}$ yield practically identical spectra and hyperfine parameters, it is strange that the present authors can detect such contamination. In fact I would maintain that this interpretation is incorrect. i) opx and cpx are easy to distinguish (one is bright green, the other not) when producing the separates for analysis. ii) This particular sample, FRB 1350, is yields a very low equilibration temperature. It is to be expected that the cation ordering will be different and more extreme at low $\mathrm{T}$. This may yield a spectrum where the high velocity components of $\mathrm{Fe} 2+$ have more distinct hyperfine parameters, producing essentially separate peaks rather than just one broad asymmetric peak.

$\mathrm{R}$ - Ok, we agree. On renewed examination of the spectrum the hyperfine parameters of the contaminating phase fit to olivine, not cpx. We adjusted the text accordingly. Equation (6) was also modified according to the revised Fe3+/Fetot ratio of Opx FRB1350. The regression statistics have slightly improved. 
It is stated in the text that refitting of the opx spectra from Canil \& O'Neill (1996) yielded similar results compared to the original results. However, a look in figure 3 reveals significantly different results. (see below). This must be assessed.

R - No. We stated that "We obtained similar results to Canil and O'Neill (1996) using their fitting approach." and then "the Opx spectra were re-fitted". We then only state that "the change in Fe3+/Fetot values from our reprocessing of the Canil and O'Neill (1996) data compared to their original values is minor and does not alter the general conclusions presented in their paper." But this does not mean that there is no change.

B) Investigating the partitioning of $\mathrm{Fe} 3+$ between opx and garnet was the stated goal of this manuscript. The authors suggest that, while no temperature dependence on $\mathrm{DFe} 3+$ is observable, that a correlation with pressure is apparent. From the data presented, I find this unconvincing. The claimed pressure dependence relies only on the position of the dataset from Dariganga, for which the opxs have distinctly different compositions compared to the rest of the data. Consideration of the Dariganga data is inconsistent, however. These data are also anomalous in terms of the temperature vs DFe3+ plot, but here nothing is made of the difference. In addition, it is clear in Fig. 2 that the Dariganga locality is very anomalous in terms of P-T conditions. It is difficult to lump together the Dariganga samples equilibrated at $\sim 2 \mathrm{GPa}$ (and high $\mathrm{T}$ ) with the other samples all equilibrated at 4-6 GPa (and lying on plausible mantle geotherms). $\mathrm{R}$ - We totally disagree with this comment. Dariganga is different but not anomalous, it records P-T conditions that are very typical of off-craton mantle sections. Earth's lithospheric mantle is not made only of cratons. To stress this further, we have emphasized in a number of places in the text and in Fig. 2 the off-craton imprint of Dariganga vs. the on-craton imprint of the other xenoliths.

However, we accept that the description and interpretation of the relationships between DFe3+ and P-T-X deserved some clarification as well as some more caution. We have significantly expanded the text in the "Results" section and added the following comment in the "Discussion" section: "The good agreement between measured and calculated InDFe3+ Opx/Grt (Fig. 6) suggests that most of the observed variability can effectively be explained by the influence of $\mathrm{P}$ and $\mathrm{NaOpx}$ on $\mathrm{Opx} / \mathrm{Grt} \mathrm{Fe3+}$ partitioning." In addition, with the revised Fe3+/Fetot ratio of Opx FRB1350 (see above) the Pdependency of InDFe3+ becomes even clearer (see Fig. 3b).

In addition, I find it interesting that the original data from Canil \& O'Neill indeed show a $\mathrm{P}$ - and T-dependence for $\mathrm{DFe} 3+$ and are even more or less consistent with the Dariganga data in both Fig. $3 a$ and $3 \mathrm{~b}$. A comment needs to be made about this. $\mathrm{R}$ - This suggestion does not make much sense, inasmuch as we refitted Canil \& O'Neill's data in order to improve their accuracy. There is no point to stick with the original data.

In terms of the data presented, the dashed line in Fig. $3 \mathrm{~b}$ has no real significance (i.e. a $\mathrm{P}$-dependence is not consistent with the data. In Fig. 3c, it is unclear what is meant by residual In DFe3+, why not just plot In DFe3+ like for the other diagrams?

$\mathrm{R}$ - We do not agree that that regression 'has no real significance'. A regression is a regression and has some residuals. And we show that these residuals do not appear to be simply due to random scattering but show some dependency on $\mathrm{Na}$ in Opx. This way of presenting the data is more effective than an additional InD vs Na plot, in which most of this information would be masked by the concomitant independent effect of $P$. We have tried to clarify the text to better explain the rationale of our analysis. We have also added in the 'Discussion' section that "the good agreement between measured and calculated InDFe3+ (Fig. 6) suggests that most of the observed DFe3+ variability can effectively be explained by the influence of $\mathrm{P}$ and $\mathrm{NaOpx}$ on Opx/Grt Fe3+ partitioning."

It is also better to use cations pfu rather than wt $\% \mathrm{Na2O}$, especially when differences in composition are apparent. Why is the correlation between $\mathrm{Fe} 3+$ and $\mathrm{Na}$ considered to be a "second-order" compositional control? What would be first order? Why weren't the crystal chemical effects of $\mathrm{Fe} 3+$ incorporation in opx first discussed in terms of opx chemistry instead of going directly into the partitioning behavior?

$\mathrm{R}$ - We think the last comment was a valuable suggestion and have added a two-plot figure (now Fig. 4a,b) to show compositional relationships in Opx. They further support 
our hypothesis that Na may have a minor, but significant role in controlling $\mathrm{Fe} 3+$ partitioning in Opx. We have provided an alternative expression for InDFe3+ (modified equation 6) which considers cations pfu only.

C) The discussion of $\mathrm{Fe} 3+$ incorporation in terms of $\mathrm{Al}$ exchange is reasonable, but the arguments are not clear. As suggested, Al-substitution in opx can occur through different mechanisms. It would have been interesting to see a plot of $\mathrm{Al}$ vs $\mathrm{Fe} 3+$ (here the Al not involved in Tschermaks substitution). If there is no relationship here, then the above arguments need to be reconsidered. Also, the relatively large amounts of $\mathrm{Al}$ in the Dariganga opxs should be discussed in this regard.

$\mathrm{R}$ - The relationships with $\mathrm{Al}$ are now discussed in the 'Results' section and illustrated in the new Fig. 4a. We do not think that a plot of Fe3+ vs 'Al not involved in Tschermaks substitutions' would be very informative: what we have is a set of samples equilibrated under very different P-T conditions and most of the Al variability is due to $\mathrm{P}-\mathrm{T}$ variations rather than to a simple Fe3+-Al substitution; moreover, allocation of cation species such as $\mathrm{Cr}$ and $\mathrm{Ti}$ to Tschermaks-type vs Na-bearing components is not straightforward and would require subjective assumptions.

D) The authors test the importance of $\mathrm{Fe} 3+$ incorporation on thermobarometric calculations (p.18 and appendix). This is a useful exercise. However, the range of fO2 values chosen to make the test makes no petrological sense. It is not reasonable to take a worldwide range (which is related to many different situations) and assume that such a range could apply to a single locality or even a single sample. The assumed range is far beyond what one might call a worst-case scenario. This needs to be reassessed with a smaller range in conceivable $\mathrm{fO}_{2}$ values. My feeling is that it ends up making little difference in the P-T calculations, considering the overall uncertainties, particularly when applying such an empirical thermometer as Nimis \& Grütter (2010). This is already apparent in Fig. 7. Obviously what is important is that systematic differences between oxidized and more reduced domains could produce artefacts that might lead to false conclusions about the local geotherm. It would also be of interest to know what degree of oxidation is required to cause a significant "bias" in the calculated temperature and that the application of the opx-garnet thermometer should be avoided for samples where strong metasomatism is suspected.Is there evidence from other studies that the required high $\mathrm{fO} 2$ values are realistic for the localities mentioned here? $\mathrm{R}$ - We do not agree with this comment. Our goal was not to consider possible redox changes for 'a specific locality', but to investigate the possible effect of redox conditions in general, within the overall fO2 range of mantle rocks. In common practice, thermobarometry is done without even knowing the redox conditions, and we know from Fig. 7 (now Fig. 8) that these may be very different for different localities AND also for different xenoliths from one single locality. Here we explore what could be the maximum potential bias on commonly obtained P-T estimates. We do not aim to simulate 'realistic redox changes for a specific locality'.

I was also surprised to see choice of samples used for this test. Of the 5 samples listed, only one was actually from this study. FRB 1350 from Canil and O'Neill (1996) was used, but this was the one sample the authors singled out as having contamination in the opx sample used for Mössbauer (which probably not the case; see above). The remaining 3 samples are not documented at all. So how do we know that the $\mathrm{Na}$ content of opx was reliable? or that the $\mathrm{Fe} 3+$ contents were determined in the same way as in this study?

$\mathrm{R}$ - The chosen samples are ideal in that (i) they show excellent agreement between $\mathrm{T}$ estimates using internally-consistent thermometers (including one that is sensitive to redox variations), and (ii) they record apparent redox conditions which are 'average' compared to other mantle xenoliths. Our other samples do not meet the second criterion. We have further clarified these points in the text (see Appendix). We also note that (i) any possible inaccuracy in Opx Fe3+ data for these samples does not affect our calculations at all, and (ii) since the aim of this exercise is to assess 'relative' variations in final P-T estimates, possible small interlab discrepancies in Fe3+/Fetot ratios for Grt extracted from the literature and from this work cannot significantly alter our conclusions. We have added a sentence at the and of the Appendix to emphasize this point.

As for sodium uncertainties, yes they might be a problem, as we had already admitted in the text: "The above exercises contain a significant degree of uncertainty, which derives from uncertainties in the oxybarometer of Stagno et al. (2013), which is used to 
readjust the $\mathrm{Fe} 3+/ \mathrm{Fetot}$ in the $\mathrm{Grt}$, in the calibration of dependency of DFe3+ on $\mathrm{P}$ and $\mathrm{NaOpx}$, in the determination of Na2OOpx in the test samples, and in the mechanisms of incorporation of $\mathrm{Fe} 3+$ in Opx and its effects on the activity of Al-components. Nonetheless, the results cast doubts on the reliability of many existing thermobarometric estimates....". And finally, at the end of the Conclusions: "An experimental verification of Fe3+ partitioning systematics, e.g., by high-resolution Mössbauer analysis of Opx-Grt pairs re-equilibrated under controlled P-T-O2 and with varying $\mathrm{Na} 2 \mathrm{O}$ contents, would be desirable to derive a more robust evaluation..."

Minor comments

P.6. Doucet 2013, 2014 are not in the refernce list

R - Ok, added.

P.7. Was there any loss of $\mathrm{Na}$ due to the long counting times and high beam current? Were any precautions taken to prevent Na loss?

$\mathrm{R}$ - We added a sentence in which we explain that this has not been a problem. We observed no systematic decrease in measured $\mathrm{Na}$ contents using the longer times and higher currents.

P.15. What is the point of eq. 6 ? Weight percent is a poor variable to use. Why not cations pfu? That is more thermodynamically relevant.

$\mathrm{R}$ - We have provided an alternative expression for InDFe3+ (modified equation 6) which considers cations pfu only.

P.15. following from eq.4 it might be better to cast the partitioning of $\mathrm{Fe} 3+$ on an equal number of oxygen's basis. i.e. either a 6 or 12 oxygen basis for both phases.

$\mathrm{R}$ - Ok. We have cast all formulas to a common 4-cation basis.

P.15. line 47. Na partitioning being favored by high T? Partitioning between opx and garnet?

$\mathrm{R}$ - No, between opx and cpx. We have clarified the text.

P.16. should give the exchange equilibrium for the mass action equation (8).

R - Ok, added.

P.19. line 26. So what is "strongly oxidized"? how high? Are these realistic values? $\mathrm{R}$ - See our reply to point $\mathrm{D}$ above.

P.20 line 23. What started out as a "rough" P-dependence for DFe3+ has now become a "significant" dependence. This is not fair statement here, especially considering the comments made above.

R - Agreed. Text changed.

P.20. line 35. Why is it stated here "at least $9 \%$ " (Fe3+/Fetot). This gives the false impression that much more $\mathrm{Fe} 3+$ can be expected although there is no such evidence presented here. Evidence from spinel peridotites argues that Fe3+/Fetot ratios are always low in opx (Woodland et al. Lithos, 2009).

$\mathrm{R}$ - We are showing for the first time that Opx can contain significant Fe3+, but we cannot maintain that $9 \%$ is the maximum possible value. So we see no problem with our sentence. However, the sentence was slightly changed to clarify that we are only considering garnet-facies Opx here.

Figure 4. This figure doesn't tell me much, other than eq. 6 more or less fits the data. But we knew this already from the quoted R-value of the fit. More interesting would be to plot the calculated DFe3+ in Fig 3c.

$R$ - The R-value alone does not allow one to properly judge the quality of the fit, as it does not discriminate between the presence e.g. of any anomalous data and any unresolved non-linearity in the measured vs calculated values. Therefore we have kept the Figure. We do not understand the second suggestion: if it is a plot of calculated DFe3+ vs. $\mathrm{Na} 2 \mathrm{O}$, we do not understand what this could tell us, since $\mathrm{Na} 2 \mathrm{O}$ is already considered in the regression.

Figure 5. These 2 diagrams are essentially the same as those in Fig. 3 except with a change in scale for the y-axis. Are they really necessary? 
$\mathrm{R}$ - This is true, but the first pair shows a parameter that is commonly used in studies on the Fe3+ distribution (most people would expect to see it in plots), whereas the second pair (now Fig. 7) shows a parameter that quantifies the robustness (or non robustness) of thermometric estimates vs redox conditions (which is the basis for our evaluation of thermometric implications). And the distribution of the data in the two pairs of plots are not identical anyway. So we think it is worth keeping both Figures.We agree, however, that the second plot vs T is useless, so we have only kept the plot vs $\mathrm{P}$ in the new Fig. 7. 


\section{$\mathrm{Fe}^{3+}$ partitioning systematics between orthopyroxene and garnet in mantle peridotite xenoliths and implications for thermobarometry of oxidized and reduced mantle rocks}

Paolo Nimis ${ }^{1, *}$, Alexey Goncharov ${ }^{2}$, Dmitri A. Ionov ${ }^{3}$, Catherine McCammon ${ }^{4}$

${ }^{1}$ Dipartimento di Geoscienze, Università di Padova, Italy

${ }^{2}$ Institute of Earth Sciences, Saint-Petersburg State University \& IPGG RAS SaintPetersburg, Russia

${ }^{3}$ Géosciences Montpellier, CNRS-UMR 5243 - Université Montpellier II, 34095 Montpellier, France

${ }^{4}$ Bayerisches Geoinstitut, Universität Bayreuth, D-95440 Bayreuth, Germany

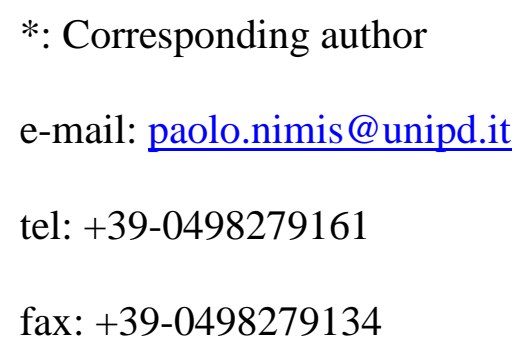


Abstract We have investigated the partitioning of $\mathrm{Fe}^{3+}$ between orthopyroxene (Opx) and garnet (Grt) in well-equilibrated mantle xenoliths using Mössbauer spectroscopy. The samples cover a wide range of $P-T$ conditions $\left(2.1-6.6 \mathrm{GPa}, 690-1,412{ }^{\circ} \mathrm{C}\right)$ and geothermal gradients, and are thus representative for Earth's upper mantle in both oncraton and off-craton continental settings. Garnet has $\mathrm{Fe}^{3+} / \mathrm{Fe}_{\text {tot }}$ ratios of $0.03-0.13$ and $\mathrm{Fe}_{2} \mathrm{O}_{3}$ contents of $0.24-1.00 \mathrm{wt} \%$. Orthopyroxene has, on average, lower $\mathrm{Fe}^{3+} / \mathrm{Fe}_{\text {tot }}$ ratios (0.01-0.09) and $\mathrm{Fe}_{2} \mathrm{O}_{3}$ contents $(0.05-0.63 \mathrm{wt} \%)$. In low-pressure, high-temperature samples, however, Opx is systematically richer in $\mathrm{Fe}_{2} \mathrm{O}_{3}$ than the coexisting Grt. The $\mathrm{Fe}^{3+} \mathrm{Opx} / \mathrm{Grt}$ partition coefficient $\left(D_{\mathrm{Fe}^{3+}}^{\mathrm{Opx} / \mathrm{Grt}}\right)$ shows no obvious relationship with temperature, but increases with decreasing pressure and with increasing $\mathrm{Na}^{\mathrm{Opx}}$. The observed Opx/Grt $\mathrm{Fe}^{3+}$ systematics imply that the Opx-Grt Fe- $\mathrm{Mg}$ exchange thermometer is not robust against redox changes if total $\mathrm{Fe}$ is treated as $\mathrm{Fe}^{2+}$. An approximate evaluation of errors on $T$ estimates due to redox effects predicts negligible deviations for strongly reduced conditions $\left(<65^{\circ} \mathrm{C}\right)$, but potentially large deviations $(>$ to $>100{ }^{\circ} \mathrm{C}$ ) for strongly oxidized conditions, especially at very high pressure and when both $P$ and $T$ are calculated by iteration.

Keywords Ferric iron, Orthopyroxene, Garnet, Mantle xenoliths, Thermobarometry 


\section{Introduction}

Studies of the distribution of ferric iron in mantle minerals have provided important insights into the redox state and geochemical processes in the Earth. Measured $\mathrm{Fe}^{3+} / \mathrm{Fe}_{\text {tot }}$ ratios in garnet and spinel from xenoliths have been used to derive oxygen fugacity profiles for several upper mantle sections (e.g., Luth et al. 1990; Luth and Canil 1993; Woodland and Peltonen 1999; Woodland and Koch 2003; McCammon and Kopylova 2004; Lazarov et al. 2009; Yaxley et al. 2012; Creighton et al. 2009, 2010; Goncharov and Ionov 2012; Goncharov et al. 2012). These data are of paramount importance for our understanding of processes involving volatile-bearing metasomatic fluids and melts active in the lithosphere today and during its evolution, including those involved in diamond formation and Earth's degassing (Woodland and Koch 2003; Shirey et al. 2013; Stagno et al. 2013).

A large number of $\mathrm{Fe}^{3+}$ analyses are now available for garnet, pyroxenes and spinel, which are the most important carriers of $\mathrm{Fe}^{3+}$ in the upper mantle. The contents and distribution of $\mathrm{Fe}^{3+}$ among these minerals are controlled by crystal-chemical constraints and $P-T$ conditions and are affected by partial melting and metasomatism (Frost and McCammon 2008). It was recognized that in sub-cratonic mantle sections garnet $\mathrm{Fe}^{3+} / \mathrm{Fe}_{\text {tot }}$ ratios and garnet/clinopyroxene $\mathrm{Fe}^{3+}$ partition coefficients tend to increase with temperature (Woodland and Koch 2003; Canil and O'Neill 1996; Woodland 2009). In addition, owing to stabilization of the $\mathrm{Fe}^{2+}{ }_{3} \mathrm{Fe}^{3+}{ }_{2} \mathrm{Si}_{3} \mathrm{O}_{12}$ ("skiagite") component in garnet with pressure, oxygen fugacity has been shown to be driven to lower values relative to the FMQ buffer with increasing depth (Gudmundsson and Wood 1995). 
Despite the large amount of data on $\mathrm{Fe}^{3+}$ distribution in mantle rocks, specific information on the partitioning of $\mathrm{Fe}^{3+}$ between orthopyroxene (hereafter Opx) and garnet (hereafter Grt) is still very scarce. Predictive theoretical modeling of this partitioning is hampered by the lack of accurate thermodynamic data for $\mathrm{Fe}^{3+}$-bearing Opx. Empirical modeling is also problematic due to the paucity of analytical data for Opx. To our knowledge, reliable partitioning data for Opx-Grt pairs are restricted to a set of eight mantle xenoliths, which were analyzed by conventional Mössbauer spectroscopy by Canil and O’Neill (1996), and two compositionally zoned Opx-Grt pairs from metasomatized xenoliths, which were analyzed by high-spatial-resolution Mössbauer spectroscopy by McCammon et al. (2001). Two additional pairs were reported for orogenic garnet peridotites by Malaspina et al. (2012), who used complementary analytical techniques for the determination of ferric iron, i.e., flankmethod electron probe micro-analysis (EPMA) for Grt and electron energy-loss spectroscopy for Opx.

Nimis and Grütter (2010) showed that the distribution of $\mathrm{Fe}^{3+}$ between Opx and Grt in Canil and O'Neill's (1996) xenoliths is dependent on equilibrium $P-T$ conditions, implying a significant effect of mantle redox state on Opx-Grt Fe-Mg-exchange thermometry. Unfortunately, the strong correlation between $P$ and $T$ in these samples did not allow discrimination of the net effects of $P$ and $T$ on $\mathrm{Fe}^{3+}$ partitioning. More recently, Matjuschkin et al. (2014) performed experiments in the CFMAS peridotitic system at 5 GPa and $1,100-1,400{ }^{\circ} \mathrm{C}$ under strongly oxidized conditions and measured $\mathrm{Fe}^{3+}$ contents in the garnets with the flank method. These authors observed a marked improvement of Opx-Grt temperature estimates using the Harley (1984) Fe-Mg exchange thermometer 
when the significant $\mathrm{Fe}^{3+}$ contents in the garnets were accounted for and suggested that $\mathrm{Fe}^{3+} / \mathrm{Fe}_{\mathrm{tot}}$ ratios in the coexisting orthopyroxenes should be comparatively small.

To gain a better insight into the partitioning systematics of ferric iron between Opx and Grt under conditions relevant to Earth's upper mantle, we have undertaken a Mössbauer study of Opx-Grt pairs in well-equilibrated xenoliths from both on-craton and off-craton mantle sections, covering a wide $P-T$ field. The results provide new indications on the mechanisms of incorporation of $\mathrm{Fe}^{3+}$ in Opx and have significant implications for mantle thermobarometry.

\section{Materials and methods}

Sample selection, microstructures and compositions

The samples used in the present work were selected among well-studied peridotite xenoliths to cover a range of $P-T$ conditions representative of garnet-facies lithospheric mantle in cratonic and off-craton regions (Table 1). All selected samples show wellequilibrated microstructures. We avoided using samples showing significant alteration or any evidence of chemical disequilibrium, such as significant compositional variations in any minerals, poor consistency between thermometric estimates using independent, mutually-consistent thermometers (cf. Nimis and Grütter 2010) or poor consistency between $\mathrm{fO}_{2}$ estimates using independent, garnet-based and spinel-based oxybarometers (cf. Goncharov and Ionov 2012). 
The selected off-craton peridotites $(\mathrm{N}=6)$ are from the Barun-Yargait eruption center within the Late Cenozoic Dariganga alkali basaltic field in SE Mongolia (Ionov et al. 1999; Ionov 2002). The peridotites are fertile to moderately refractory garnet lherzolites (2.7-3.9 wt $\% \mathrm{Al}_{2} \mathrm{O}_{3}$ in whole-rocks) containing 54-66\% olivine, 19-27\% Opx, 6-13\% clinopyroxene (hereafter $\mathrm{Cpx}$ ) and 4-11\% Grt; one sample (BY-18) contains accessory spinel (Table 1). They are coarse- to medium-grained rocks with protogranular textures. The grain size is similar for all silicate minerals. The mineral grains typically have curved boundaries and irregular shapes. Pyroxenes show no optical zoning or unmixing. Garnets have thin kelyphite rims. No volatile-bearing minerals (mica, amphibole, apatite) or silicate glass have been found. Veined peridotites or pyroxenite xenoliths are very uncommon in the whole xenolith suite. The peridotites are fresh and have positive loss on ignition (LOI) values, indicating that the gain of mass due to oxidation of $\mathrm{FeO}$ to $\mathrm{Fe}_{2} \mathrm{O}_{3}$ on heating is greater than the loss of volatiles introduced by alteration.

The selected cratonic peridotites $(\mathrm{N}=12)$ are from the Udachnaya-East kimberlite pipe in the central Siberian craton. The samples are a subset of the xenolith collection described by Doucet et al. (2013, 2014), Goncharov et al. (2012) and Ionov et al. (2010), and were collected in the 420-640 $\mathrm{m}$ depth range in the diamond mine pit from unusually fresh kimberlites. Details on petrographic features, major and trace element compositions of whole-rocks and minerals, and oxygen fugacity estimates can be found in the quoted papers. The rocks range in composition from Cpx-bearing harzburgite to lherzolite to Opx-bearing wehrlite (Table 1), and show no or little alteration (commonly with positive LOI). Four samples (U29, U64, U283, U501) are coarse (undeformed), seven (U70, U183, U267, Y-10, Y-19, 87/70, 87/97) are sheared and one (U10) is 
transitional (incipient deformation with $\leq 10 \%$ of olivine as neoblasts). One of the coarse xenoliths (U283) contains accessory spinel.

Chemical analysis

Major element compositions of minerals used in the present study were determined by wavelength-dispersive spectroscopy electron microprobe analysis at different laboratories. The minerals were analyzed in grain mounts or thin sections. Samples from Dariganga were analyzed at Macquarie University (Sydney) with a Cameca SX-50 instrument at $15 \mathrm{kV}$ voltage and $20 \mathrm{nA}$ current, using natural and synthetic oxide and silicate minerals as standards and the PAP matrix correction. Analyses for U-series samples from Udachnaya are the same as those reported in Ionov et al. (2010) and were obtained at the Laboratoire Magmas et Volcans (Clermont-Ferrand) on a CAMECA SX100 using $15 \mathrm{kV}$ voltage, $15 \mathrm{nA}$ current and counting times of 10-20 s for peaks and 5$10 \mathrm{~s}$ for background; standards were natural and synthetic minerals; the ZAF correction was applied. The other samples from Udachnaya were analyzed or re-analyzed at Padova IGG-CNR with a CAMECA SX-50 and at Clermont-Ferrand with a CAMECA SX-100 using higher currents $(20 \mathrm{kV}, 40 \mathrm{nA})$ and longer counting times for $\mathrm{Al}, \mathrm{Cr}, \mathrm{Ca}$ and $\mathrm{Na}$ in pyroxenes ( $40 \mathrm{~s}$ peak, $40 \mathrm{~s}$ background) in order to minimize propagation of analytical errors on thermobarometric estimates and optimize the analysis of Na in Opx. No systematic decrease in measured $\mathrm{Na}$ contents was observed using the higher currents and longer counting times, which excludes significant underestimation due to migration of this element under the electron beam. Analytical standards for pyroxenes and olivine were diopside (for $\mathrm{Si}$ and $\mathrm{Ca}$ ), albite (for $\mathrm{Na}$ ), orthoclase (for $\mathrm{K}$ ) and pure oxides (for 
$\mathrm{Mg}, \mathrm{Al}, \mathrm{Cr}, \mathrm{Fe}, \mathrm{Mn}$ and Ti). For garnet, pyrope was used as a standard for $\mathrm{Mg}$ and $\mathrm{Si}$. The CAMECA-PAP program was used to convert X-ray counts into weight percent oxides. The analyses are reported in Table 2 .

Mössbauer analysis

Pure Grt, Opx and Cpx grains were handpicked under a microscope from 0.5 to $2.0 \mathrm{~mm}$ size fractions of crushed and sieved rock material. Owing to the small size of some xenoliths and low modal proportions of Cpx, sufficient Cpx separates for Mössbauer analysis could be obtained only for nine of the investigated samples. The valence state of iron and its structural position in the minerals were determined using a SM-1201 Mössbauer spectrometer at the IPGG RAS (Saint-Petersburg, Russia) at room temperature in a constant acceleration mode over a velocity range of $\pm 7 \mathrm{~mm} / \mathrm{s}$ with a nominal $50 \mathrm{mCi}{ }^{57} \mathrm{Co}$ source in a $\mathrm{Rh}$ matrix. The spectrometer was calibrated relative to metallic iron at room temperature. The minerals were crushed in an agate capsule filled with acetone to avoid iron oxidation in contact with air, pressed in plastic discs and fixed on a special aluminum holder, ensuring an angle between gamma rays and absorber of $54.7^{\circ}$, to avoid asymmetry of the spectra due to preferred orientation of mineral grains. The density of the natural iron in the absorber was about $5 \mathrm{mg} / \mathrm{cm}^{3}$.

The spectra were approximated by a sum of Lorentzian lines using the MOSSFIT( software. The relative amounts of $\mathrm{Fe}^{2+}$ and $\mathrm{Fe}^{3+}$ and their site positions in the crystal lattice were determined from integral doublet intensities and hyperfine parameters, assuming equal Mössbauer effect probabilities for $\mathrm{Fe}^{2+}$ and $\mathrm{Fe}^{3+}$ at different sites for Opx and different recoil-free fractions of Fe in octahedral and dodecahedral sites for Grt. 
Constraints on the equality of halfwidths (HW) and integral intensities of the lines in each doublet component of quadrupole splitting (QS) were imposed during spectra fitting. The quality of experimental spectra was assessed by background intensity and the quality of fitting by chi-square distribution.

The fitting model for Grt included a single QS doublet for $\mathrm{Fe}^{2+}$ and $\mathrm{Fe}^{3+}$. The relative peak widths and areas of the $\mathrm{Fe}^{2+}$ doublet, assigned to dodecahedral (distorted cube) site occupancy, were left unconstrained to account for spectra asymmetry (Amthauer et al. 1976). The doublet attributable to octahedrally coordinated $\mathrm{Fe}^{3+}$ was constrained to have components with equal widths and intensities. The $\mathrm{Fe}^{3+} / \mathrm{Fe}_{\text {tot }}$ values obtained were corrected for different recoil-free fractions (Woodland and Ross 1994).

The fitting model for Opx and Cpx included two QS doublets for $\mathrm{Fe}^{2+}$ and one for $\mathrm{Fe}^{3+}$. Although previous studies (e.g. Luth and Canil 1993; Canil and O’Neill 1996), used three QS doublets for $\mathrm{Fe}^{2+}$ in Opx in the fitting procedure, this approach led to unreasonably small HW. Addition of the extra doublet is not statistically justified when the lines overlap by more than their HW, where the errors of hyperfine parameters increase dramatically (Dollase, 1975). We also note that adding the extra doublet for $\mathrm{Fe}^{2+}$ did not alter $\mathrm{Fe}^{3+/} \mathrm{Fe}_{\text {tot }}$ ratios. Therefore, to reach best fitting results, exclude peak overlap and minimize errors, only two QS doublets for $\mathrm{Fe}^{2+}$ were used to fit Opx spectra.

The hyperfine parameters and calculated proportions of $\mathrm{Fe}^{2+}$ and $\mathrm{Fe}^{3+}$ at different sites, calculated from HW and integral intensities of lines in QS doublets, are reported in Tables 3 to 5 . The hyperfine parameters of $\mathrm{Fe}^{3+}$ doublets in Opx are consistent with octahedral coordination (Annersten et al., 1978). No additional lines were observed in any of the spectra, which confirms the absence of other mineral phases, including possible exsolutions. The absolute errors on the $\mathrm{Fe}^{3+} / \mathrm{Fe}_{\text {tot }}$ ratios varied from 0.003 to 
0.017 for Opx, from 0.009 to 0.024 for Grt, and from 0.01 to 0.06 for Cpx. Two

examples of spectra pairs showing different partitioning of $\mathrm{Fe}^{3+}$ between Opx and Grt are shown in Figure 1.

Mössbauer spectra of Opx, Cpx and Grt from mantle xenoliths that had been obtained by conventional Mössbauer spectroscopy by Canil and O’Neill (1996) were reprocessed for this study using the same software and fitting approach used for our samples to ensure robust comparison of the new and old data. Seven sets of spectra could be retrieved from the original Canil and O'Neill (1996) files. We obtained similar results to Canil and O’Neill (1996) using their fitting approach; however, for several Opx spectra we observed that the fitting residuals were larger than the baseline scatter and indicated unequal areas of the main doublet components. This asymmetry is likely caused by a slight preferred orientation of crystallites arising from the nature of the sample mount; therefore the Opx spectra were re-fitted allowing the two $\mathrm{Fe}^{2+}$ doublets to have components with equal HW but unequal intensity according to the fitting approach of McCammon et al. (2000). One of the spectra (sample FRB1350) showed a contribution from olivine, which was estimated to be roughly $13 \%$ of the total area based on the intensity of the high QS impurity. Accordingly, an empirical correction was made to the $\mathrm{Fe}^{3+} / \mathrm{Fe}_{\text {tot }}$ ratio in Opx based on the well established observation that olivine contains no $\mathrm{Fe}^{3+}$. For the garnets, the same fitting model used for our samples produced $\mathrm{Fe}^{3+} / \mathrm{Fe}_{\text {tot }}$ values within 0.01 of the data reported in Canil and O'Neill (1996), provided the latter were corrected for different recoil-free fractions. Most of our refitted $\mathrm{Fe}^{3+} / \mathrm{Fe}_{\text {tot }}$ data for the clinopyroxenes were within 0.02 of those reported in Canil and O'Neill (1996), with only two samples at $0.03-0.04$ of the originally reported values. The results of the refitting are reported in Tables 3 to 5 . We emphasize that the change in $\mathrm{Fe}^{3+} / \mathrm{Fe}_{\text {tot }}$ 
values from our reprocessing of the Canil and O'Neill (1996) data compared to their original values is minor and does not alter the general conclusions presented in their paper.

Thermobarometry

The pressures and temperatures of equilibration of the studied xenoliths and of the reprocessed Canil and O'Neill (1996) data (Table 1) were calculated using a combination of the Taylor (1998) two-pyroxene thermometer and Nickel and Green (1985) Opx-Grt barometer recommended by Nimis and Grütter (2010). Given the presence of a few sodium-rich Opx in our data set, we adopted the modified version of the Nickel and Green (1985) barometer proposed by Carswell (1991). This modification was neither expressly favored nor disfavored by Nimis and Grütter (2010), who showed that both versions of the barometer are consistent with constraints imposed by natural xenoliths and experiments in peridotitic systems. Carswell's (1991) version only diverges from the original Nickel and Green (1985) for Opx with $\mathrm{Na}>\mathrm{Cr}+\mathrm{Fe}^{3+}+\mathrm{Ti}$, for which it yields somewhat higher pressures (up to 1.2 GPa higher in our data set; Table 1) and is claimed to be more robust. Owing to the large relative uncertainties in the determination of the small $\mathrm{Fe}^{3+}$ contents in $\mathrm{Opx}, \mathrm{Fe}^{3+}$ was neglected in the application of Carswell's (1991) correction.

Only two samples from Udachnaya (U267 and 87/70) showed discrepancies between Opx-Grt (Nimis and Grütter 2010) and two-pyroxene (Taylor 1998) temperatures slightly larger than the assumed safety threshold of $\pm 70{ }^{\circ} \mathrm{C}$ proposed by Nimis and Grütter (2010), i.e., $+96{ }^{\circ} \mathrm{C}$ and $-77^{\circ} \mathrm{C}$, respectively. Neither of these two samples, 
however, showed anomalous behavior in terms of Opx/Grt Fe ${ }^{3+}$ distribution compared with the other samples.

Three of the samples from the Canil and O’Neill (1996) set for which the Mössbauer spectra were refitted, i.e., BD1140, BD1150 and BD1354, show less than optimal agreement between internally-consistent clinopyroxene-based (Taylor 1998 or Nimis and Taylor 2000) and Opx-based thermometers (Brey and Köhler 1990, with correction in Nimis and Grütter 2010) $\left(\Delta T=100-165^{\circ} \mathrm{C}\right) . P-T$ estimates for these samples should thus be used with caution. Therefore, these three samples will be used for general comparative purposes, but not for quantitative evaluation of $\mathrm{Fe}^{3+}$ systematics.

\section{Results}

The samples studied in this work cover a wide range of estimated $P-T$ conditions (2.16.6 GPa, $\left.690-1,412{ }^{\circ} \mathrm{C}\right)$ and geothermal gradients, and are thus representative for Earth's upper mantle in both on-craton and off-craton continental settings (Fig. 2). Garnet has $\mathrm{Fe}^{3+} / \mathrm{Fe}_{\text {tot }}$ ratios of $0.03-0.13$ and $\mathrm{Fe}_{2} \mathrm{O}_{3}$ contents of $0.24-1.00 \mathrm{wt} \%$. Orthopyroxene has, on average, lower $\mathrm{Fe}^{3+} / \mathrm{Fe}_{\text {tot }}$ ratios (0.01-0.09) and $\mathrm{Fe}_{2} \mathrm{O}_{3}$ contents $(0.05-0.63$ wt $\%)$. In the low-pressure, high-temperature Dariganga suite, however, Opx is systematically richer in $\mathrm{Fe}_{2} \mathrm{O}_{3}$ than the coexisting Grt (Table 2). Such systematic $\mathrm{Fe}^{3+}$-enrichment appears to be unrelated to the abundance of other phases competing for $\mathrm{Fe}^{3+}$, since the modal ranges of Cpx (6-13 vol\%) and Grt (3.5-11 vol\%) in Dariganga xenoliths overlap those in the other investigated samples $(\mathrm{Cpx}=1.4-16 \mathrm{vol} \%$; $\mathrm{Grt}=2.1-13 \mathrm{vol} \%)$, and spinel only occurs in minor amounts $(<0.5$ vol\%) in one Dariganga and one Udachnaya 
sample (Table 1). The main reason for the enhanced partitioning of $\mathrm{Fe}^{3+}$ in Opx must therefore be found in the specific $P-T$ conditions recorded by the off-craton Dariganga xenoliths and, possibly, in specific compositional controls.

The higher $\mathrm{Fe}^{3+}$ contents in Dariganga Opx are coupled with higher ${ }^{[4]} \mathrm{Al}$ contents (Fig. 4a). The latter essentially reflects the low- $P$ and relatively high- $T$ conditions of equilibration of these samples, which are typical of the garnet-facies off-craton lithospheric mantle (Fig. 2). The association of high $\mathrm{Fe}^{3+}$ and high ${ }^{[4]} \mathrm{Al}$ suggests a major role of Tschermaks-type substitution in the incorporation of $\mathrm{Fe}^{3+}$ in Opx. In addition, the three most $\mathrm{Fe}^{3+}$-rich samples in the low- ${ }^{[4]} \mathrm{Al}$ Opx group are those with the highest $\mathrm{Na}$ content, and a correlation of $\mathrm{Fe}^{3+}$ with $\mathrm{Na}$ is also shown by all of the Dariganga samples except for one, which contains spinel (Fig. 4b). This indicates that an additional minor aegirine component $\mathrm{NaFe}^{3+} \mathrm{Si}_{2} \mathrm{O}_{6}$ may also have contributed to the incorporation of $\mathrm{Fe}^{3+}$ in Opx.

The $\mathrm{Fe}^{3+}$ Opx/Grt partition coefficient $\left(D_{\mathrm{Fe}^{3+}}^{\mathrm{Opx} / \mathrm{Grt}}=\frac{\left(\mathrm{Fe}^{3+}\right)^{\mathrm{Opx}}}{\left(\mathrm{Fe}^{3+}\right)^{\mathrm{Grt}}}\right.$, at. per 4-cation formula unit) shows no obvious relationship with temperature and a roughly negative correlation with pressure (Fig. 3a,b). Detailed examination of the relationships between $\ln D_{\mathrm{Fe}^{3+}}^{\mathrm{Opx} / \mathrm{Grt}}$ and $P$ showed that the scatter in Figure $3 \mathrm{~b}$ was at least in part correlated with changes in the Na content of Opx. This is illustrated by a plot of the residuals of a $\ln D_{\mathrm{Fe}^{3+}}^{\mathrm{Opx} / \mathrm{Grt}}$ vs. $P$ linear regression, which show a positive correlation with the Na content in Opx (Fig. 3c). Such a correlation is consistent with the inferred contribution of aegirine component to $\mathrm{Fe}^{3+}$ incorporation and suggests an additional compositional control on the partitioning of $\mathrm{Fe}^{3+}$ between Opx and Grt. The original data of Canil and 
O’Neill (1996) are systematically shifted to higher $D_{\mathrm{Fe}^{3+}}^{\mathrm{Opx} / \mathrm{Grt}}$, but the refitted data are in good agreement with our data if the effect of $\mathrm{Na}$ and the uncertainties in $P, D_{\mathrm{Fe}^{3+}}^{\mathrm{Opx} / \mathrm{Grt}}$ and $\mathrm{Na}$ content are taken into account (Fig. 3c).

The partitioning behavior observed in our Opx-Grt pairs is in contrast with existing reports for natural mantle and experimental Cpx-Grt pairs: these show enhanced partitioning of $\mathrm{Fe}^{3+}$ to Grt with increasing temperature (Canil and O’Neill 1996; Woodland 2009; Purwin et al. 2013), a tendency which is confirmed also by our CpxGrt pairs (Fig. 5a). A correlation between $\mathrm{Fe}^{3+}$ and $\mathrm{Na}$ in $\mathrm{Cpx}$ is also apparent in our data (Table 2), in line with previous observations in garnet peridotites (Woodland 2009; Malaspina et al. 2012). Owing to the complex combination of $P-T$ and compositional effects, the distribution of $\mathrm{Fe}^{3+}$ between the pyroxenes varies significantly among different samples $\left(D_{\mathrm{Fe}^{3+}}^{\mathrm{Opx} / \mathrm{Cpx}}=0.1-0.8\right.$; Fig. 5b). In particular, the high $D_{\mathrm{Fe}^{3+}}^{\mathrm{Opx} / \mathrm{Cpx}}$ in Dariganga xenoliths $(0.5-0.7)$ is probably due mostly to a combination of relatively high $T$, low $P$ conditions and moderate $\mathrm{Na}^{\mathrm{Cpx}}$ contents. Quantitative evaluation of $\mathrm{Opx} / \mathrm{Cpx}$ $\mathrm{Fe}^{3+}$ partitioning systematics is beyond the scope of the present work. We only emphasize that estimates of $\mathrm{Opx} \mathrm{Fe}^{3+}$ contents from $\mathrm{Fe}^{3+}$ measured in $\mathrm{Cpx}$, based on linear regression of data extracted from limited sets of samples from on-craton mantle settings (cf. Canil and O’Neill 1996), are probably unreliable when applied to Opx-Cpx pairs from different mantle environments.

\section{Discussion}


Because the thermodynamic properties of $\mathrm{Fe}^{3+}$-bearing Opx end-members are unknown, a rigorous thermodynamic treatment of the equilibria involved in the $\mathrm{Fe}^{3+}$ partitioning between Opx and Grt is not possible. However, the topology of the possible relevant reactions and a few approximations allow us to make some qualitative predictions, which may explain the observed partitioning systematics.

Assuming $\mathrm{Fe}^{3+}$ enters into Opx in octahedral coordination, in line with our Mössbauer data, the equilibrium controlling $\mathrm{Fe}^{3+}$ partitioning at constant $f_{\mathrm{O}_{2}}$ can be expressed by an $\mathrm{Fe}^{3+}-\mathrm{Al}$ exchange reaction of the type

$$
1 / 2 M_{3} \mathrm{Fe}^{3+}{ }_{2} \mathrm{Si}_{3} \mathrm{O}_{12}+\mathrm{MgAl}_{2} \mathrm{SiO}_{6} \rightarrow \mathrm{MgFe}^{3+} \mathrm{AlSiO}_{6}+1 / 2 M_{3} \mathrm{Al}_{2} \mathrm{Si}_{3} \mathrm{O}_{12}
$$

$$
\text { Grt Opx Opx Grt }
$$

where $\mathrm{M}$ represents a divalent cation (essentially, $\mathrm{Mg}, \mathrm{Fe}^{2+}$ or $\mathrm{Ca}$ ). At equilibrium,

$$
-\frac{\Delta G^{\circ}}{R T}=\ln K_{\mathrm{Fe}^{3+}-\mathrm{Al}}^{\mathrm{Grt}-\mathrm{Opx}}=\ln \left(K_{D} \cdot K_{\gamma}\right)=\ln \frac{\left(\mathrm{Fe}^{3+}\right)^{\mathrm{Opx}}}{\left(\mathrm{Fe}^{3+}\right)^{\mathrm{Grt}}}-\ln \frac{\left(\mathrm{Al} \mathrm{M}_{1}\right)^{\mathrm{Opx}}}{(\mathrm{Al})^{\mathrm{Grt}}}+\ln K_{\gamma},
$$

where elements are atomic fractions in octahedral sites and $\ln K_{\gamma}$ includes all non-ideal terms. Since reactants and products in reaction (1) are the same and the coordination number of the exchanged cations does not change in the reaction, the volume change of the reaction should be small. Large extrapolation of Domeneghetti et al.'s (1995) data for Pbca orthopyroxenes allows us to predict a molar volume of $\sim 6.1 \mathrm{~J} / \mathrm{bar}$ for the $\mathrm{MgFe}^{3+} \mathrm{AlSiO}_{6}$ end-member. As expected, the calculated $\Delta V^{\circ}$ of reaction (1) is small (ca. $-0.1 \mathrm{~J} / \mathrm{bar}$ ), hence the $P$ dependency of the reaction should also be small. Since the Al 
term in Equation (2) typically decreases with pressure in garnet peridotites, owing to the net-transfer reaction

$$
\begin{array}{ccc}
\mathrm{MgAl}_{2} \mathrm{SiO}_{6}+\mathrm{Mg}_{2} \mathrm{Si}_{2} \mathrm{O}_{6} & \rightarrow \mathrm{Mg}_{3} \mathrm{Al}_{2} \mathrm{Si}_{3} \mathrm{O}_{12} \\
\mathrm{Opx} & \mathrm{Opx} & \text { Grt }
\end{array}
$$

the sum of the other right-hand terms in Equation (2) should also do so in order to maintain the $P$ dependency of $\ln K_{\mathrm{Fe}^{3+}-\mathrm{Al}}^{\mathrm{Grt}-\mathrm{Opx}}$ small. If the $\ln K_{\gamma}$ term is sufficiently small or does not vary significantly with $P$, then the $\frac{\left(\mathrm{Fe}^{3+}\right)^{\mathrm{Opx}}}{\left(\mathrm{Fe}^{3+}\right)^{\mathrm{Grt}}}$ ratio (i.e., $D_{\mathrm{Fe}^{3+}}^{\mathrm{Opx} / \mathrm{Grt}}$ ), should decrease with increasing pressure.

An alternative equilibrium, again with $\mathrm{Fe}^{3+}$ in octahedral coordination, is

$$
\begin{array}{cccc}
M \mathrm{Fe}^{3+} \mathrm{AlSiO}_{6}+M_{2} \mathrm{Si}_{2} \mathrm{O}_{6} & \rightarrow 1 / 2 M_{3} \mathrm{Fe}^{3+}{ }_{2} \mathrm{Si}_{3} \mathrm{O}_{12}+1 / 2 M_{3} \mathrm{Al}_{2} \mathrm{Si}_{3} \mathrm{O}_{12} . \\
\mathrm{Opx} & \text { Opx } & \text { Grt } & \text { Grt }
\end{array}
$$

This net-transfer reaction involves an increase of mean coordination number for both divalent and trivalent cations and is therefore expected to be favored by pressure. In fact, a similar equilibrium, with $\mathrm{Cr}$ in lieu of $\mathrm{Fe}^{3+}$, was experimentally calibrated as a geobarometer by Nickel (1989).

If $\mathrm{Fe}^{3+}$ is assumed to enter Opx to a minor extent also in tetrahedral coordination (cf. Annersten et al. 1978), then the following net-transfer reaction may become relevant:

$$
M \mathrm{Fe}^{3+}{ }_{2} \mathrm{SiO}_{6}+M_{2} \mathrm{Si}_{2} \mathrm{O}_{6} \rightarrow M_{3} \mathrm{Fe}^{3+}{ }_{2} \mathrm{Si}_{3} \mathrm{O}_{12}
$$


Opx Opx Grt

The topology of this reaction is similar to that of equilibrium (3) (with $\mathrm{Al}$ instead of $\mathrm{Fe}^{3+}$ ), on which the Opx-Grt barometer is based (e.g., Nickel and Green 1985). Therefore, regardless of the mechanisms of incorporation of $\mathrm{Fe}^{3+}$ in $\mathrm{Opx}$, the $D_{\mathrm{Fe}^{3+}}^{\mathrm{Opx} / \mathrm{Grt}}$ partition coefficient can be predicted to be negatively correlated with pressure, which is in line with our results (Fig. 3).

The positive correlation of the residuals of the $\ln D_{\mathrm{Fe}^{3+}}^{\mathrm{Opx} / \mathrm{Grt}}$ vs. $P$ regression with the $\mathrm{Na}$ content in Opx (Fig. 3c) suggests that $\mathrm{Na}$ also favors incorporation of $\mathrm{Fe}^{3+}$ in $\mathrm{Opx}$, probably as an aegirine component. In our data set, no compositional variable other than the Na content was found to have a significant relationship with these residuals. Weighted regression of our data plus the refitted Canil and O'Neill's (1996) data yielded the following expression for $D_{\mathrm{Fe}^{3+}}^{\mathrm{Opx} / \mathrm{Grt}}$ as a function of $P$ and $\mathrm{Na}^{\mathrm{Opx}}$ :

$\ln D_{\mathrm{Fe}^{3+}}^{\mathrm{Opx} / \mathrm{Grt}}=\ln \frac{\left(\mathrm{Fe}^{3+}\right)^{\mathrm{Opx}}}{\left(\mathrm{Fe}^{3+}\right)^{\mathrm{Grt}}}=-0.0551(47) \cdot P(\mathrm{GPa})+181(23) \cdot \mathrm{Na}^{\mathrm{Opx}}-0.12(23)$,

$\left(\mathrm{R}^{2}=0.86\right)$,

with atoms per 4-cation formula units for both Opx and Grt. The good agreement between measured and calculated $\ln D_{\mathrm{Fe}^{3+}}^{\mathrm{Opx} / \mathrm{Grt}}$ (Fig. 6) suggests that most of the observed $D_{\mathrm{Fe}^{3+}}^{\mathrm{Opx} / \mathrm{Grt}}$ variability can effectively be explained by the influence of $P$ and $\mathrm{Na}^{\mathrm{Opx}}$ on Opx/Grt $\mathrm{Fe}^{3+}$ partitioning. Since the partitioning of $\mathrm{Na}$ in Opx is favored by $T$ in $\mathrm{Cpx}-$ bearing garnet peridotites (cf. Brey and Köhler 1990), the sodium terms in Equation (6) 
may also incorporate some minor temperature effect. Attempts to consider explicitly $T$ in the regressions were, however, unsuccessful.

The practical utility of Equation (6) as a geobarometer is hindered by the relatively small sensitivity of $\ln D_{\mathrm{Fe}^{3+}}^{\mathrm{Opx} / \mathrm{Grt}}$ to $P$ and by difficult accurate measurement of $\mathrm{Fe}^{3+}$ concentrations in both Opx and Grt and of $\mathrm{Na}_{2} \mathrm{O}$ in sodium-poor Opx. More interestingly, the equations can be used to estimate $\mathrm{Fe}^{3+}$ contents in orthopyroxenes from mantle peridotites in which only garnets have been analyzed for $\mathrm{Fe}^{3+}$. The $\mathrm{Fe}^{3+}$ systematics expressed by Equation (6) may thus be of help in calculations of $\mathrm{Fe}_{2} \mathrm{O}_{3}$ budgets and fluxes during geochemical processes involving mantle rocks. A detailed investigation of these issues is beyond the scope of the present work. We only note that, given its relatively large modal proportion in Grt peridotites and significant affinity for $\mathrm{Fe}^{3+}$, especially at moderate pressure, Opx may represent one of the most important $\mathrm{Fe}^{3+}$ carriers in Earth's lithospheric mantle.

Implications for mantle thermobarometry

Opx-Grt Fe-Mg exchange thermometry is based on the equilibrium

$$
\begin{array}{cccc}
\mathrm{MgSiO}_{3}+\frac{1}{3} \mathrm{Fe}_{3} \mathrm{Al}_{2} \mathrm{Si}_{3} \mathrm{O}_{12} & \rightarrow \mathrm{FeSiO}_{3}+\frac{1}{3} \mathrm{Mg}_{3} \mathrm{Al}_{2} \mathrm{Si}_{3} \mathrm{O}_{12} \\
\mathrm{Opx} & \mathrm{Grt} & \mathrm{Opx} & \text { Grt }
\end{array}
$$

and depends on 
$\ln K_{D_{\mathrm{Fe}^{2+}-\mathrm{Mg}}^{\mathrm{Grt}-\mathrm{Opx}}}^{\mathrm{g}}=\ln \frac{\left(\mathrm{Fe}^{2+}\right)^{\mathrm{Grt}}}{\left(\mathrm{Fe}^{2+}\right)^{\mathrm{Opx}}}+\ln \frac{(\mathrm{Mg})^{\mathrm{Opx}}}{(\mathrm{Mg})^{\mathrm{Grt}}}$

In common practice, total $\mathrm{Fe}$ is treated as $\mathrm{Fe}^{2+}$, therefore variations in ferric iron contents may affect temperature estimates. Following Nimis and Grütter (2010), the difference between the $\ln K_{D} \mathrm{~s}$ calculated using total $\mathrm{Fe}$ and $\mathrm{Fe}^{2+}$ is given by

$\ln K_{D \mathrm{Fe}_{\text {tot }}-\mathrm{Mg}}^{\mathrm{Grt}}-\ln K_{D_{\mathrm{Fe}^{2+}-\mathrm{Mg}}^{\mathrm{Grt}}}^{\mathrm{G}}=\ln \frac{\left(\mathrm{Fe}_{\mathrm{tot}}\right)^{\mathrm{Grt}}}{\left(\mathrm{Fe}_{\mathrm{tot}}\right)^{\mathrm{Opx}}}-\ln \frac{\left(\mathrm{Fe}^{2+}\right)^{\mathrm{Grt}}}{\left(\mathrm{Fe}^{2+}\right)^{\mathrm{Opx}}}=\ln \frac{\left(\mathrm{Fe}^{2+} / \mathrm{Fe}_{\mathrm{tot}}\right)^{\mathrm{Opx}}}{\left(\mathrm{Fe}^{2+} / \mathrm{Fe}_{\mathrm{tot}}\right)^{\mathrm{Grt}}}=$ $=\ln \frac{1-\left(\mathrm{Fe}^{3+} / \mathrm{Fe}_{\text {tot }}\right)^{\mathrm{Opx}}}{1-\left(\mathrm{Fe}^{3+} / \mathrm{Fe}_{\text {tot }}\right)^{\mathrm{Grt}}}$.

The difference is null only if the $\frac{1-\left(\mathrm{Fe}^{3+} / \mathrm{Fe}_{\text {tot }}\right)^{\mathrm{Opx}}}{1-\left(\mathrm{Fe}^{3+} / \mathrm{Fe}_{\text {tot }}\right)^{\mathrm{Grt}}}$ ratio (hereafter, 'the iron ratio') is equal to unity, i.e., if Opx and Grt have the same $\mathrm{Fe}^{3+} / \mathrm{Fe}_{\text {tot }}$ ratio. If this condition is not satisfied, then temperature estimates may be affected by changes in redox conditions, which will affect the $\mathrm{Fe}^{3+} / \mathrm{Fe}_{\text {tot }}$ ratios in both minerals. Therefore, temperature estimates will only be accurate if $\mathrm{Fe}^{3+}$ partitioning and redox conditions in the mantle are comparable to those in the samples used to calibrate the thermometer or if the contributions of ferric iron in the two minerals compensate each other. The latter condition seems to hold for the $\mathrm{Cpx}-\mathrm{Grt}$ thermometer, at least in sodium-free systems (Purwin et al. 2013). Based on experimental data at 5 GPa, Matjuschkin et al. (2014) suggested that this condition does not apply instead to the Opx-Grt thermometer, owing to strong preferential partitioning of $\mathrm{Fe}^{3+}$ into Grt, but they did not explore the role of pressure. Nimis and Grütter (2010) recalibrated the Opx-Grt thermometer empirically, using well-equilibrated mantle xenoliths as calibrants. They found that a correction for 
pressure was needed, which was larger than expected from thermodynamic treatment of the $\mathrm{Fe}^{2+}-\mathrm{Mg}$ exchange equilibrium, and suggested that this could be due to a systematic increase of the 'iron ratio' with depth. Our results support this hypothesis (Fig. 7).

Using our observed $\mathrm{Fe}^{3+}$ partitioning systematics, we can now explore the effect of changing redox conditions on Opx-Grt thermometry on a quantitative basis. We have estimated potential variations induced on Opx-Grt temperature estimates (Nimis and Grütter 2010; hereafter TNG10) by $f \mathrm{O}_{2}$ changes within the typical upper mantle range (Fig. 8) for a set of xenoliths recording 'average' redox conditions for their respective depths of provenance (see Appendix for details of the calculations). The results (Table 6) show that conditions more oxidized than average, within the typical $f \mathrm{O}_{2}$ range of upper mantle peridotites, will produce negligible (at low $P$ ) to significant (at high $P$ ) $T$ underestimation (over $100{ }^{\circ} \mathrm{C}$ ), whereas conditions more reduced than average will always produce negligible $T$ overestimation $\left(<40^{\circ} \mathrm{C}\right)$.

Nimis and Grütter (2010) suggested that the commonly observed discrepancies between temperature estimates for mantle xenoliths using the Opx-Grt thermometer (TNG10) and the more redox-robust two-pyroxene thermometer of Taylor (1998; hereafter, TTA98), using the same input $P$, could be due either to redox effects (i.e., highly oxidized or highly reduced conditions) or to kinetic decoupling of the fast $\mathrm{Fe}-\mathrm{Mg}$ and slow $\mathrm{Ca}-\mathrm{Mg}$ equilibria due to transient heating. Our results now allow us to refine this premise. Figure 9 shows TNG10 - TTA98 discrepancies for a few sets of xenoliths and the maximum potential bias due to redox effects, as derived from data in Table 6. It appears that large positive TNG10 - TTA98 discrepancies, such as those shown by some Jagersfontein xenoliths (Fig. 9a), cannot be ascribed to redox variations and are most likely accounted for by short-term thermal perturbations at depth and consequent 
disequilibrium. Large negative TNG10 - TTA98 discrepancies, such as those shown by some Jagersfontein, Slave or Nikos xenoliths (Fig. 9a-c) might in part be explained by a high $f \mathrm{O}_{2}$, although disequilibrium or inconsistencies of the TNG10 thermometer for specific $P-T-X$ conditions cannot be excluded.

If $P$ is not kept fixed and both $T$ and $P$ are calculated by iteration according to common practice, the bias on temperature estimates can be considerably amplified. Even so, deviations due to strongly reduced conditions remain small in all cases $\left(<65^{\circ} \mathrm{C}\right)$ and both positive and negative in sign (Table 6). This is because the increase of $\mathrm{Al}$ that is assumed to compensate for the decrease of $\mathrm{Fe}^{3+}$ in Opx (see Appendix) determines a decrease in the $P$ calculated with the $\mathrm{Opx}-\mathrm{Grt}$ barometer, which in turn tends to counteract the effect of decreasing total $\mathrm{Fe}$ on $T$ estimates, owing to the positive dependency of the Opx-Grt thermometer on $P$. The calculated pressures still remain within only $0.3 \mathrm{GPa}$ of those calculated with the original mineral compositions. Owing to the low $\mathrm{Al}$ in Opx coexisting with Grt, the Al-dependent $P$ estimates may instead be extremely sensitive to the $\mathrm{Al} \rightarrow \mathrm{Fe}^{3+}$ substitution imposed by strongly oxidized conditions. In this case, the corresponding deviations on both $P$ and $T$ estimates become erratic, from strongly negative to strongly positive (Table 6), depending on even modest differences in the original $\mathrm{Al}$ and $\mathrm{Na}$ contents in Opx.

The above exercises contain a significant degree of uncertainty, which derives from uncertainties in the oxybarometer of Stagno et al. (2013), which is used to readjust the $\mathrm{Fe}^{3+} / \mathrm{Fe}_{\mathrm{tot}}$ in the Grt, in the calibration of $\left(\mathrm{Fe}^{3+}\right)^{\mathrm{Opx}} /\left(\mathrm{Fe}^{3+}\right)^{\mathrm{Git}}$ dependency on $P$ and $\mathrm{Na}^{\mathrm{Opx}}$, in the determination of $\mathrm{Na}_{2} \mathrm{O}^{\mathrm{Opx}}$ in the test samples, and in the mechanisms of incorporation of $\mathrm{Fe}^{3+}$ in Opx and its effects on the activity of Al-components (see 
Appendix). Nonetheless, the results cast doubts on the reliability of many existing thermobarometric estimates for Cpx-free garnet harzburgites and Grt-Opx inclusions in diamonds, for which no independent, sufficiently accurate control on $T$ and $P$ estimates is generally possible (Nimis and Grütter 2010). It is noteworthy that any inconsistency in published $T$ estimates for Cpx-free xenoliths based on Opx-Grt thermobarometry will be difficult to recognize, because the $T$-dependency of the Opx-Grt barometer will force the $P-T$ points to move roughly along the same conductive geotherm on which the 'good' $P-T$ points will fall (Brey and Köhler 1990).

\section{Conclusions}

The partitioning of $\mathrm{Fe}^{3+}$ between orthopyroxene and garnet in our set of mantle xenoliths shows no obvious relationship with temperature, but appears to vary with pressure and the $\mathrm{Na}_{2} \mathrm{O}$ content of the orthopyroxene. This result is unlike previous observations for clinopyroxene-garnet pairs (cf. Woodland 2009; Purwin et al. 2013). As a consequence, the proportion of $\mathrm{Fe}^{3+}$ over total $\mathrm{Fe}$ in garnet-buffered mantle orthopyroxene is not uniformly low, as commonly assumed, but varies from $1 \%$ (in some high- $P$ and low-Na orthopyroxenes) to at least $9 \%$ (in some low- $P$, relatively high-Na orthopyroxenes equilibrated with garnet). Some low- $P$, high-Na (high- $T$ ) mantle orthopyroxenes contain more $\mathrm{Fe}_{2} \mathrm{O}_{3}$ than coexisting garnets.

In common practice, redox conditions for garnet peridotites are estimated assuming that $\mathrm{Fe}^{3+}$ in Opx is negligible, so that $f \mathrm{O}_{2}$ and activity of ferrosilite in Opx can simply be calculated using total Fe concentrations (Gudmundsson and Wood 1995; Stagno et al. 
2013). Recalculating ferrsosilite activities in our samples using only $\mathrm{Fe}^{2+}$ instead of $\mathrm{Fe}_{\mathrm{tot}}$, produces a decrease in the calculated $f_{\mathrm{O}_{2}}$ of only $0.02 \log$ units. Therefore, although higher than commonly assumed, the observed $\mathrm{Fe}^{3+} / \mathrm{Fe}_{\text {tot }}$ ratios of up to $9 \%$ in Opx should not affect $f \mathrm{O}_{2}$ estimates based on currently available oxybarometers.

The $\mathrm{Fe}^{3+}$ systematics observed in the studied xenoliths instead imply that the OpxGrt $\mathrm{Fe}-\mathrm{Mg}$ exchange thermometer is not robust against redox changes if total $\mathrm{Fe}$ is treated as $\mathrm{Fe}^{2+}$. In particular, variations in $\mathrm{Fe}^{3+}$ partitioning with pressure in mantle peridotites may account for some systematic discrepancies observed between experimentally calibrated Opx-Grt and two-pyroxene thermometers (cf. Nimis and Grütter 2010). An approximate evaluation of errors on Opx-Grt temperatures due to redox effects predicts negligible deviations of $P-T$ estimates for strongly reduced conditions, but potentially large deviations for strongly oxidized conditions, especially at very high pressure and when both $P$ and $T$ are calculated by iteration. Therefore, comparisons between $P-T$ estimates derived using Opx-Grt and two-pyroxene thermometers, a common necessity when studying, for instance, both clinopyroxenebearing and clinopyroxene-free peridotites, may be problematic if redox conditions are unknown. An experimental verification of $\mathrm{Fe}^{3+}$ partitioning systematics, e.g., by highresolution Mössbauer analysis of $\mathrm{Opx}-$ Grt pairs re-equilibrated under controlled $P-T-$ $\mathrm{fO}_{2}$ and with varying $\mathrm{Na}_{2} \mathrm{O}$ contents, would be desirable to derive a more robust evaluation and, hopefully, recalibration of Opx-Grt thermometers for mantle peridotites.

Acknowledgments We are grateful to Dante Canil for providing access to his original dataset. Sula Milani is thanked for her help in retrieving the old Mössbauer files. Formal reviews by Bob Luth and two anonymous referees helped us to improve the paper. PN 
acknowledges financial support by MIUR ex60\%. DAI thanks Igor Ashchepkov for providing some of the xenoliths used in this study and acknowledges financial support from the French CNRS, including PNP-INSU and PICS grants, and from the Australian Research Council including Research fellowship and grants in 1994-1998. 


\section{Appendix}

Estimation of maximum bias on Opx-Grt temperature estimates due to changing redox conditions

Figure 8 shows a compilation of existing $\mathrm{fO}_{2}$ data for mantle xenoliths worldwide, recalculated using input $P-T$ values obtained with the thermobarometer combinations recommended by Nimis and Grütter (2010). This choice significantly reduced the scatter of points (especially for Diavik) compared to earlier published versions of this plot (e.g., Stagno et al. 2013). Correction of Canil and O’Neill's (1996) Mössbauer data for different recoil-free fractions in Grt (Table 4) produced a slight decrease in calculated $\mathrm{fO}_{2}$ of about $0.6 \Delta \log$ units. The plot shows the well-known overall decrease of FMQnormalized oxygen fugacity with increasing mantle depth and a range for $f \mathrm{O}_{2}$ at each depth.

From this compilation, we selected five xenoliths coming from different depths and recording 'average' redox conditions for their particular depths of provenance (Table 6; Fig. 8). We calculated the Opx-Grt temperatures for these xenoliths with the thermometer version of Nimis and Grütter (2010) (hereafter TNG10) at $P$ given by the thermobarometers combination recommended by the same authors, using total Fe. The TNG10 thermometer was calibrated against a large set of mantle xenoliths from localities worldwide and should therefore be robust when applied to mantle rocks characterized by 'average' redox conditions. All selected xenoliths showed very good agreement $\left(\Delta T<60{ }^{\circ} \mathrm{C}\right)$ between thermometric estimates using the internally consistent thermometers recommended by Nimis and Grütter (2010). This indicates good 
equilibrium and also confirms that redox conditions in the xenoliths were indeed 'average' and compatible with the TNG10 thermometer calibration (cf. Nimis and Grütter 2010). Therefore the calculated $P-T$ conditions should be reliable.

We then allowed $f \mathrm{O}_{2}$ for each of the selected xenoliths to vary to the maximum and minimum values expected for the mantle at the corresponding depths, as indicated by our compilation in Figure 8 . We estimated the $\mathrm{Fe}^{3+} / \mathrm{Fe}_{\text {tot }}$ ratios in the garnets at these maximum and minimum redox conditions by reversing the oxybarometer of Stagno et al. (2013), and those in the coexisting orthopyroxenes by using the $\mathrm{Fe}^{3+}$ partitioning systematics obtained in our work (cf. Equation 6). The mineral compositions were

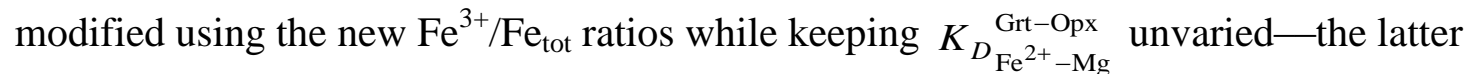
depends essentially on $T$, therefore keeping it fixed corresponds to keeping $T$ fixed. An increase (or decrease) in the $\mathrm{Fe}^{3+} / \mathrm{Fe}_{\text {tot }}$ ratio thus determined a net increase (or decrease) in the total $\mathrm{Fe}$ content (actually $\mathrm{Fe}^{3+}$ ), which was compensated by varying the $\mathrm{Al}^{3+}+\mathrm{Cr}^{3+}$ contents by the same magnitude at constant $\mathrm{Al} / \mathrm{Cr}$ ratio. Since the solid solution model for garnet which is used in the oxybarometer of Stagno et al. (2013) is sensitive to the Al and $\mathrm{Cr}$ contents, the $\mathrm{Fe}^{3+} / \mathrm{Fe}_{\text {tot }}$ ratios had to be readjusted by iteration, although the effect of this correction was found to be minimal.

We then recalculated the TNG10 temperatures using the modified total Fe contents in both orthopyroxenes and garnets, either keeping $P$ fixed or recalculating both $P$ and $T$ iteratively. The $P-T$ estimates obtained for the selected xenoliths using the original mineral compositions and the compositions modified for their respective maximum and minimum redox conditions are reported in Table 6 . We emphasize that the aim of this exercise was to assess 'relative' variations on final $P-T$ estimates, and that possible 
1 small interlab discrepancies in $\mathrm{Fe}^{3+} / \mathrm{Fe}_{\text {tot }}$ ratios for Grt extracted from the literature and from this work do not significantly alter our results. 


\section{References}

Annersten H, Olesch M, Seifert FA (1978) Ferric iron in orthopyroxene: a Mössbauer spectroscopic study. Lithos 11:301-310

Ballhaus C (1995) Is the upper mantle metal-saturated? Earth Planet Sci Lett 132:75-86

Boyd FR, Mertzman SA (1987) Composition and structure of the Kaapvaal lithosphere, southern Africa. In: Mysen BO (ed.) Magmatic Processes: Physiochemical Principles. Geochem Soc Spec Publ 1:13-24

Brey GP, Köhler T (1990) Geothermobarometry in four-phase lherzolites II. New thermobarometers, and practical assessment of existing thermobarometers. J Petrol 31:13531378

Canil D, O'Neill HStC (1996) Distribution of ferric iron in some upper-mantle assemblages. J Petrol 37:609-635

Caro G (2000) Petrography of the Kennedy Lake orangeite and its mantle xenoliths. Unpubl MSc thesis, University of British Columbia, $100 \mathrm{p}$

Carswell DA (1991) The garnet-orthopyroxene Al barometer: problematic application to natural garnet lherzolite assemblages. Mineral Mag 55:19-31

Cox KG, Smith MR, Beswetherick S (1987) Textural studies of garnet lherzolites: evidence of exsolution origin from high-temperature harzburgites. In: Nixon PH (ed.) Mantle Xenoliths. John Wiley \& Sons, pp 537-550

Creighton S, Stachel T, Matveev S, Höfer HE, McCammon C, Luth RW (2009) Oxidation of the Kaapvaal lithospheric mantle driven by metasomatism. Contrib Mineral Petrol 157:491-504

Creighton S, Stachel T, Eichenberg D, Luth RW (2010) Oxidation state of the lithospheric mantle beneath Diavik diamond mine, central Slave craton, NWT, Canada. Contrib Mineral Petrol 159:645-657

Dollase WA (1975) Statistical limitations of Mössbauer spectral fitting. Am Miner 60: 257-264

Domeneghetti MC, Molin GM, Tazzoli V (1995) A crystal-chemical model for PBCA orthopyroxene. Am Mineral 80:253-267

Doucet LS, Ionov DA, Golovin AV (2013) The origin of coarse garnet peridotites in cratonic lithosphere: new data on xenoliths from the Udachnaya kimberlite, central Siberia. Contrib Mineral Petrol 165:1225-1242

Doucet LS, Peslier AH, Ionov DA, Brandon AD, Golovin AV, Goncharov AG, Ashchepkov IV (2014) High water contents in the Siberian cratonic mantle linked to metasomatism: an FTIR study of Udachnaya peridotite xenoliths. Geochim Cosmochim Acta 137:159-187 
Frost DJ, McCammon CA (2008) The redox state of Earth's mantle. Annu Rev Earth Planet Sci 36:389-420

Goncharov AG, Ionov DA (2012) Redox state of deep off-craton lithospheric mantle: new data from garnet and spinel peridotites from Vitim, southern Siberia. Contrib Mineral Petrol $164: 731-745$

Goncharov AG, Ionov DA, Doucet LS, Pokhilenko LN (2012) Thermal state, oxygen fugacity and $\mathrm{C}-\mathrm{O}-\mathrm{H}$ fluid speciation in cratonic lithospheric mantle: New data on peridotite xenoliths from the Udachnaya kimberlite, Siberia. Earth Planet Sci Lett 357-358:99-110

Gregoire M, Bell DR, le Roux AP (2003) Garnet lherzolites from the Kaapvaal craton (South Africa): Trace element evidence for a metasomatic history. J Petrol 44:629-657

Gudmundsson G, Wood BJ (1995) Experimental tests of garnet peridotite oxygen barometry. Contrib Mineral Petrol 119:56-67

Harley SL (1984) An experimental study of the partitioning of Fe and $\mathrm{Mg}$ between garnet and orthopyroxene. Contrib Mineral Petrol 86:359-373

Hops JJ, Gurney JJ, Harte B, Winterburn P (1989) Megacrysts and high temperature nodules from the Jagersfontein kimberlite pipe. In: Ross J (ed) Kimberlites and related rocks, vol 2, Their mantle/crust setting, diamonds and diamond exploration. Geol Soc Aus Spec Publ, vol 14, pp 759-770

Ionov DA (2002) Mantle structure and rifting processes in the Baikal-Mongolia region: geophysical data and evidence from xenoliths in volcanic rocks. Tectonophysics 351:41-60

Ionov DA, Griffin WL, O’Reilly SY (1999) Off-cratonic garnet and spinel peridotite xenoliths from Dsun-Bussular, SE Mongolia. In: Gurney JJ, Gurney JL, Pascoe MD, Richardson SH (eds) Proc 7th Int. Kimb Conf, vol 1. RedRoof Design Cape Town, pp 383-390

Ionov DA, Doucet LS, Ashchepkov IV (2010) Composition of the lithospheric mantle in the Siberian craton: New constraints from fresh peridotites in the Udachnaya-East kimberlite. $\mathbf{J}$ Petrol 51:2177-2210

Kopylova MG, Caro G (2004) Mantle xenoliths from the southeastern Slave craton: evidence for chemical zonation in a thick, cold lithosphere. J Petrol 45:1045-1067

Kopylova MG, Russel JK, Cookenboo H (1999a) Petrology of peridotite and pyroxenite xenoliths from the Jericho kimberlite: Implications for the thermal state of the mantle beneath the Slave craton, Northern Canada. J Petrol 40:79-104

Kopylova MG, Russel JK, Cookenboo H (1999b) Mapping the lithosphere below the north central Slave craton. In: Gurney JJ, Gurney JL, Pascoe MD, Richardson SH (eds), J. B. Dawson Volume, Proc 7th Int Kimb Conf, Red Roof Design Cape Town, pp 468-479 
Lazarov M, Woodland AB, Brey GP (2009) Thermal state and redox conditions of the Kaapvaal mantle: A study of xenoliths from the Finsch mine, South Africa. Lithos 112S:913-923

Luth RW, Canil D (1993) Ferric iron in mantle-derived pyroxenes and a new oxybarometer for the mantle. Contrib Mineral Petrol 113:236-248

Luth RW, Virgo D, Boyd FR, Wood BJ (1990) Ferric iron in mantle-derived garnets. Implications for thermobarometry and for the oxidation state of the mantle. Contrib Mineral Petrol 104:56-72

Malaspina N, Langenhorst F, Fumagalli P, Tumiati S, Poli S (2012) $\mathrm{Fe}^{3+}$ distribution between garnet and pyroxenes in mantle wedge carbonate-bearing garnet peridotites (Sulu, China) and implications for their oxidation state. Lithos 146-147:11-17

Matjuschkin V, Brey GP, Höfer HE, Woodland AB (2014) The influence of $\mathrm{Fe}^{3+}$ on garnetorthopyroxene and garnet-olivine geothermometers. Contrib Mineral Petrol 167:1-10

McCammon C, Kopylova MG (2004) A redox profile of the Slave mantle and oxygen fugacity control in the cratonic mantle. Contrib Mineral Petrol 148:55-68

McCammon CA, Tennant WC, Miletich RM (2000) A new method for single crystal measurements: Application to studies of mineral inclusions in diamonds. Hyper Inter 126: $241-245$

McCammon CA, Griffin WL, Shee SR, O'Neill HStC (2001) Oxidation during metasomatism in ultramafic xenoliths from the Wesselton kimberlite, South Africa: implications for the survival of diamond. Contrib Mineral Petrol 141:287-296

Nickel KG (1989) Garnet-pyroxene equilibria in the system SMACCR $\left(\mathrm{SiO}_{2}-\mathrm{MgO}-\mathrm{Al}_{2} \mathrm{O}_{3}-\mathrm{CaO}-\right.$ $\mathrm{Cr}_{2} \mathrm{O}_{3}$ ): the Cr-geobarometer. In Ross $\mathrm{J}$ (ed) Kimberlites and related rocks, vol 2, Their mantle/crust setting, diamonds and diamond exploration. Proc 4th Int Kimb Conf, Geol Soc Aus Spec Publ, vol 14, pp 901-912

Nickel KG, Green DH (1985) Empirical geothermobarometry for garnet peridotites and implications for the nature of the lithosphere, kimberlites and diamonds. Earth Planet Sci Lett 73:158-170

Nimis P, Grütter H (2010) Internally consistent geothermometers for garnet peridotites and pyroxenites. Contrib Mineral Petrol 159:411-427

Nimis P, Taylor WR (2000) Single-clinopyroxene thermobarometry for garnet peridotites. Part I. Calibration and testing of a Cr-in-Cpx barometer and an enstatite-in-Cpx thermometer. Contrib Mineral Petrol 139:541-554 
O'Neill HStC, Wall VJ (1987) The olivine-orthopyroxene-spinel oxygen geobarometer, the nickel precipitation curve, and the oxygen fugacity of the earth's upper mantle. J Petrol 28:1169-1191

Pearson DG, Boyd FR, Haggerty SE, Pasteris JD, Field SW, Nixon PH, Pokhilenko NP (1994) The characterisation and origin of graphite in cratonic lithospheric mantle: a petrological carbon isotope and Raman spectroscopic study. Contrib Mineral Petrol 115:449-466

Pollack HN, Chapman DS (1977) On the regional variations of heat flow, geotherms and lithospheric thickness. Tectonophysics 38:279-296

Purwin H, Lauterbach S, Brey GP, Woodland AB, Kleebe H-J (2013) An experimental study of the Fe oxidation states in garnet and clinopyroxene as a function of temperature in the system $\mathrm{CaO}-\mathrm{FeO}-\mathrm{Fe}_{2} \mathrm{O}_{3}-\mathrm{MgO}-\mathrm{Al}_{2} \mathrm{O}_{3}-\mathrm{SiO}_{2}$ : implications for garnet-clinopyroxene geothermometry. Contrib Mineral Petrol 165:623-639

Saltzer RL, Chatterjee N, Grove TL (2001) The spatial distribution of garnets and pyroxenes in mantle peridotites: Pressure-temperature history of peridotites from the Kaapvaal craton. J Petrol 42:2215-2229

Schmidberger SS, Francis D (1999) Nature of mantle roots beneath the North American craton: mantle xenolith evidence from Somerset Island kimberlites. Lithos 48:195-216

Shirey SB, Cartigny P, Frost DJ, Keshav S, Nestola F, Nimis P, Pearson DG, Sobolev NV, Walter MJ (2013) Diamonds and the Geology of Mantle Carbon. Rev Mineral Geochem $75: 355-421$

Smith D (1999) Temperatures and pressures of mineral equilibration in peridotite xenoliths: Review, discussion, and implications. In: Fei Y, Bertka CM, Mysen BO (eds) Mantle Petrology: Field Observations and high pressure experimentation: A tribute to Francis R. (Joe) Boyd. Geochem Soc Spec Publ, vol 6, pp 171-188

Stagno V, Ojwang DO, McCammon CA, Frost DJ (2013) The oxidation state of the mantle and the extraction of carbon from Earth's interior. Nature 493:84-88

Taylor WR (1998) An experimental test of some geothermometer and geobarometer formulations for upper mantle peridotites with application to the thermobarometry of fertile lherzolite and garnet websterite. Neues Jb Miner Abh 172:381-408

Woodland AB (2009) Ferric iron contents of clinopyroxene from cratonic mantle and partitioning behaviour with garnet. Lithos 112S:1143-1149

Woodland AB, Koch M (2003) Variation in oxygen fugacity with depth in the upper mantle beneath the Kaapvaal craton, Southern Africa. Earth Planet Sci Lett 214:295-310 
Woodland AB, Peltonen P (1999) Ferric iron contents of garnet and clinopyroxene and estimated oxygen fugacities of peridotite xenoliths from the Eastern Finland Kimberlite Province. In JJ Gurney, JL Gurney, MD Pascoe, SH Richardson (eds) Proc 7th Int Kimb Conf, pp 904-911. Red Roof Design Cape Town South Africa

Woodland AB, Ross CR (1994) A crystallographic and Mössbauer spectroscopy study of $\mathrm{Fe}_{3} \mathrm{Al}_{2} \mathrm{Si}_{3} \mathrm{O}_{12}-\mathrm{Fe}_{3}^{2+} \mathrm{Fe}_{2}^{3+} \mathrm{Si}_{3} \mathrm{O}_{12}$ (almandine-skiagite) and $\mathrm{Ca}_{3} \mathrm{Fe}_{2}^{3+} \mathrm{Si}_{3} \mathrm{O}_{12}-\mathrm{Fe}_{3}^{2+} \mathrm{Fe}_{2}^{3+} \mathrm{Si}_{3} \mathrm{O}_{12}$ (andradite-skiagite) garnet solid solutions. Phys Chem Minerals 21:117-132

Yaxley GM, Berry AJ, Kamenetsky VS, Woodland AB, Golovin AV (2012) An oxygen fugacity profile through the Siberian Craton - Fe K-edge XANES determinations of $\mathrm{Fe}^{3+} / \Sigma \mathrm{Fe}$ in garnets in peridotite xenoliths from the Udachnaya East kimberlite. Lithos 140-141:142-151 


\section{Figure Captions}

Fig. 1 Mössbauer spectra for orthopyroxene and garnet in two xenoliths showing different partitioning of $\mathrm{Fe}^{3+}$.

Fig. $2 P-T$ estimates for mantle xenoliths studied in this work. Reference geotherms after Pollack and Chapman (1977). CO'N96 $P-T$ values recalculated using compositional data in Canil and O'Neill (1996) and references therein. The fields of typical on-craton and off-craton garnet peridotites are shown for comparison.

Fig. 3 Opx-Grt Fe ${ }^{3+}$ partitioning systematics in mantle xenoliths. Error bars for $\ln D \mathrm{Fe}^{3+}$ and $\mathrm{Na}_{2} \mathrm{O}$ are at $1 \sigma$. Uncertainties on $\mathrm{Na}_{2} \mathrm{O}$ were not reported for the literature samples and were calculated as $0.026-0.08 \cdot \mathrm{Na}_{2} \mathrm{O}(\mathrm{wt} \%$ ), based on systematic relationships in our analyses using routine analytical conditions. Error bars for $P$ and $T$ were fixed to $0.4 \mathrm{GPa}, 50{ }^{\circ} \mathrm{C}$, and raised to $0.5 \mathrm{GPa}, 70{ }^{\circ} \mathrm{C}$ for samples equilibrated at $T<800{ }^{\circ} \mathrm{C}$ and for some samples showing poor agreement between internally consistent thermometers (cf. Nimis and Grütter 2010). Dashed lines indicate unweighted linear regressions through the data.

Fig. $4 \mathrm{Fe}^{3+}$ contents vs. tetrahedral $\mathrm{Al}(\mathbf{a})$ and Na contents (b) in the investigated Opx. The low- ${ }^{[4]} \mathrm{Al}$ group corresponds to the on-craton xenoliths, the high- ${ }^{[4]} \mathrm{Al}$ group consists of the off-craton Dariganga xenoliths. The dashed line in b separates the two groups. Spinel-bearing sample BY-18 falls off the trend shown by the other Dariganga samples.

Fig. 5 a Variation of Grt/Cpx $\ln D \mathrm{Fe}^{3+}$ with reciprocal $T$ in the investigated xenoliths. Shaded field: data for garnet peridotites after Woodland and Peltonen (1999), Woodland (2009), Lazarov et al. (2009), plus additional data from Canil and O'Neill (1996). As already pointed out by Canil and O'Neill (1996), the spinel-bearing, very low- $T$ sample FRB1350 falls off the main trend. b Fe ${ }^{3+}$ distribution between Opx and Cpx.

Fig. 6 Calculated (Equation 6) vs. measured $\mathrm{Fe}^{3+}$ partitioning between Opx and Grt. Data for Canil and O'Neill's (1996) samples that showed poor agreement between independent thermometric estimates were not considered in the regression. Error bars are at $1 \sigma$. Same symbols as in Fig. 2.

Fig. 7 Variation in the Grt-Opx 'iron ratio' with $P$ in mantle xenoliths. The relationship with $P$ mimics that shown by $D \mathrm{Fe}^{3+}$ (cf. Fig. 3b). Same symbols as in Fig. 2.

Fig. 8 Estimated $f_{\mathrm{O}_{2}}$ normalized to the FMQ buffer (Stagno et al. 2013) for garnet peridotite xenoliths worldwide. The EMOG/D curve corresponds to the enstatite-magnesitegraphite/diamond buffer along a cratonic geotherm (Stagno et al. 2013). The Fe-Ni precipitation curve after O'Neill and Wall (1987). Shaded field approximately indicates the diamond stability field. Dashed lines indicate the apparent typical $\mathrm{fO}_{2}$ range at various mantle depths. Arrows connect five selected well-equilibrated samples recording 'average' $f \mathrm{O}_{2}$ for their respective depth to corresponding maximum and minimum $\mathrm{fO}_{2}$ values. Sources of compositional data: Siberia - Yaxley et al. (2012), Goncharov et al. (2012); Kaapvaal - Luth et al. (1990), Lazarov et al. (2009), Creighton et al. (2009), Canil and O'Neill (1996, as revisited in this work); N and SE Slave McCammon and Kopylova (2004); Diavik - Creighton et al. (2010); Mongolia - this work. Seventeen data showing poor agreement $\left(>100^{\circ} \mathrm{C}\right)$ between independent, internally consistent pyroxene thermometers (cf. Nimis and Grütter 2010) were excluded. 
Fig. 9 Differences between temperatures calculated with the Opx-Grt thermometer (Nimis and Grütter 2010; TNG10) and the two-pyroxene thermometer (Taylor 1998; TTA98) for mantle xenoliths from different localities. All xenoliths show good equilibrium between pyroxenes based on criteria in Nimis and Grütter (2010). Shaded fields indicate the declared uncertainty (2 standard errors of estimate, $\pm 70{ }^{\circ} \mathrm{C}$ ) of the TNG10 thermometer. Dashed lines indicate the maximum predicted bias on TNG10 for strongly reducing and, respectively, strongly oxidized conditions. Several xenoliths from Jagersfontein show positive deviations well beyond estimated uncertainties, suggesting disequilibrium due to transient heating. Xenolith data from Nimis and Grütter's (2010) compilation, specifically: Jagersfontein - Boyd (pers. comm. to H. Grütter), Cox et al. (1987), Boyd and Mertzman (1987), Hops et al. (1989), Mofokeng (1998), Smith (1999), Saltzer et al. (2001), Grégoire et al. (2003); Slave - Kopylova et al. (1999a,b), Caro (2000), McCammon and Kopylova (2004), Kopylova and Caro (2004); Nikos - Schmidberger and Francis (1999). 

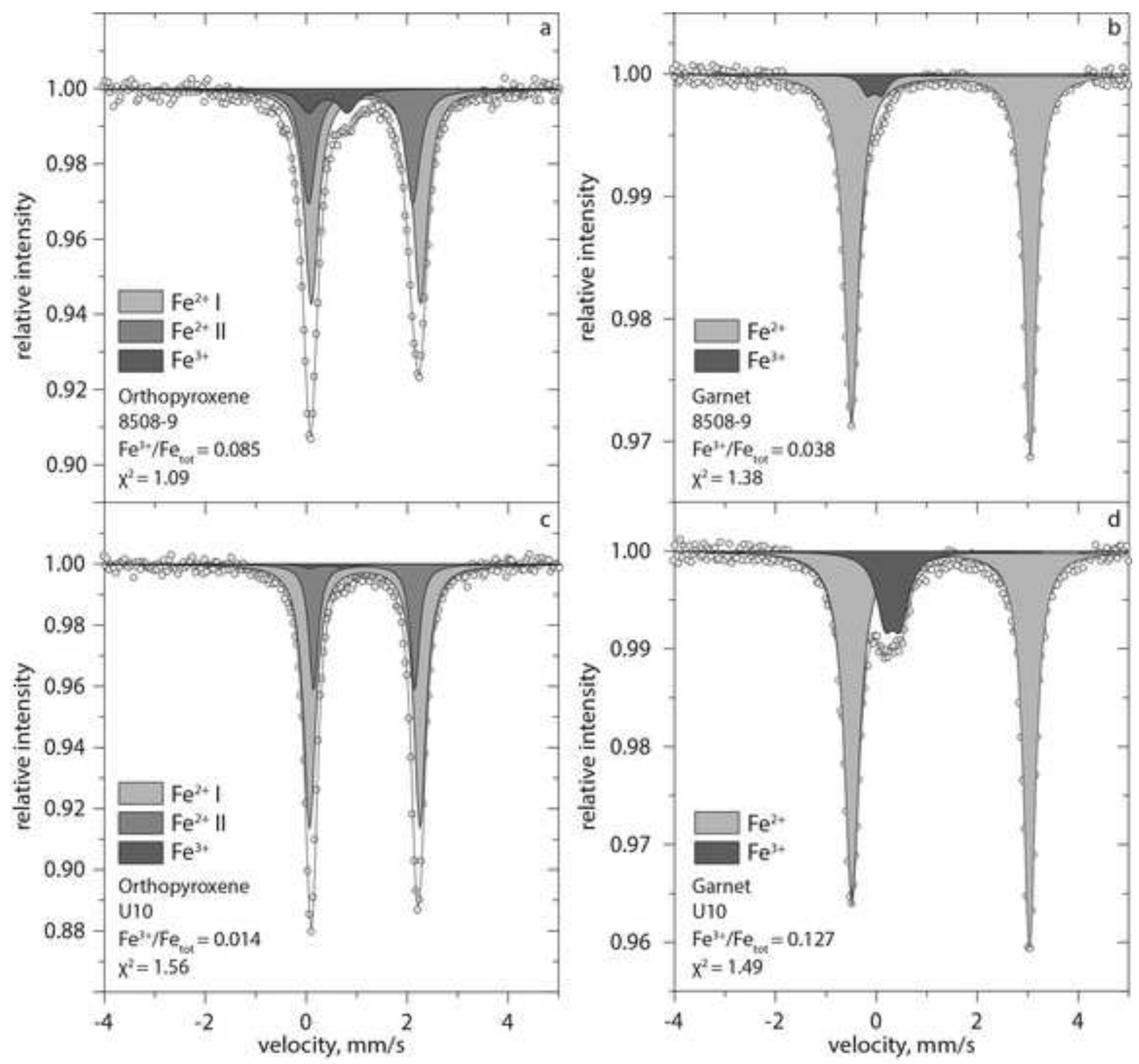


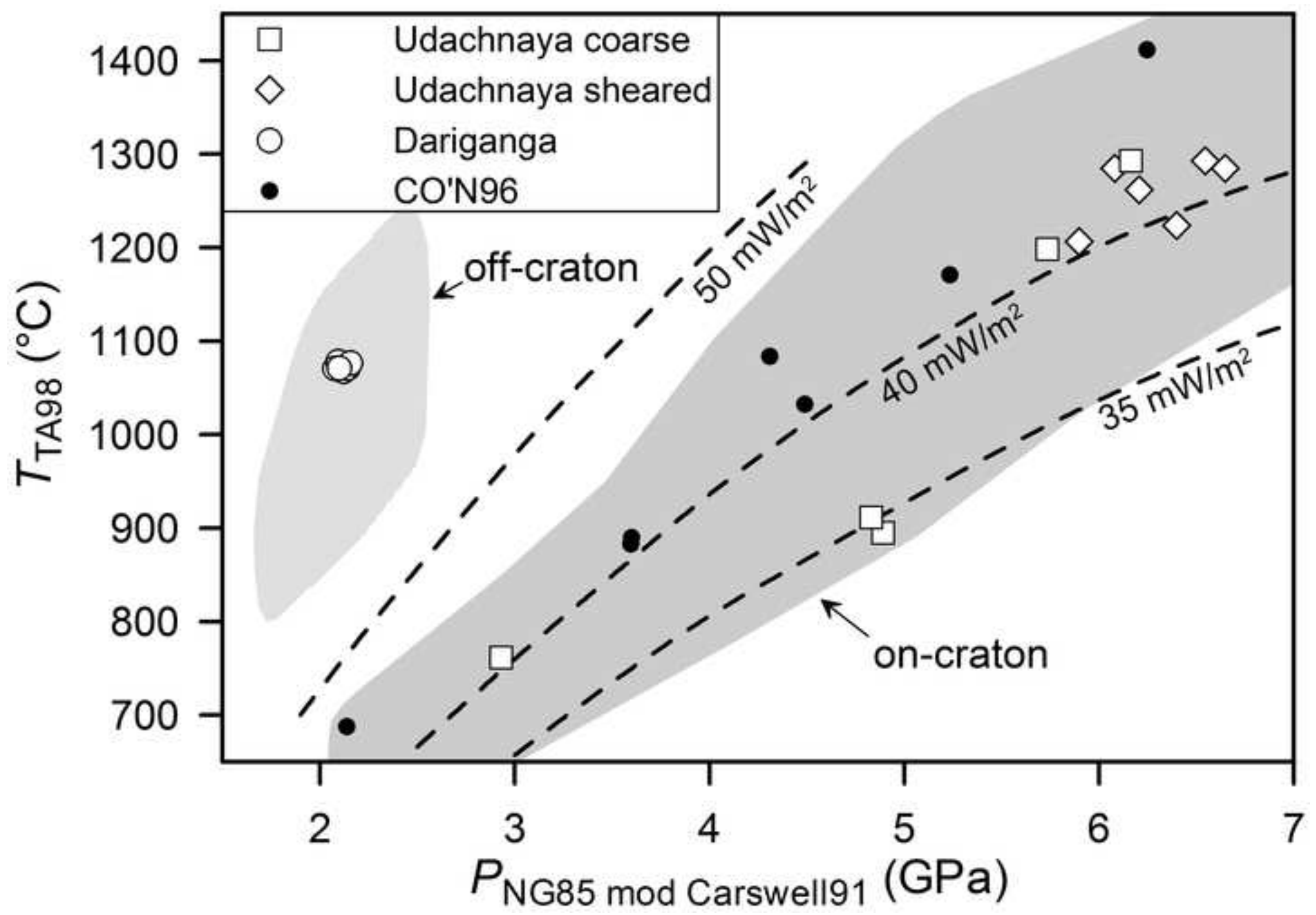


Figure 3

Click here to download high resolution image
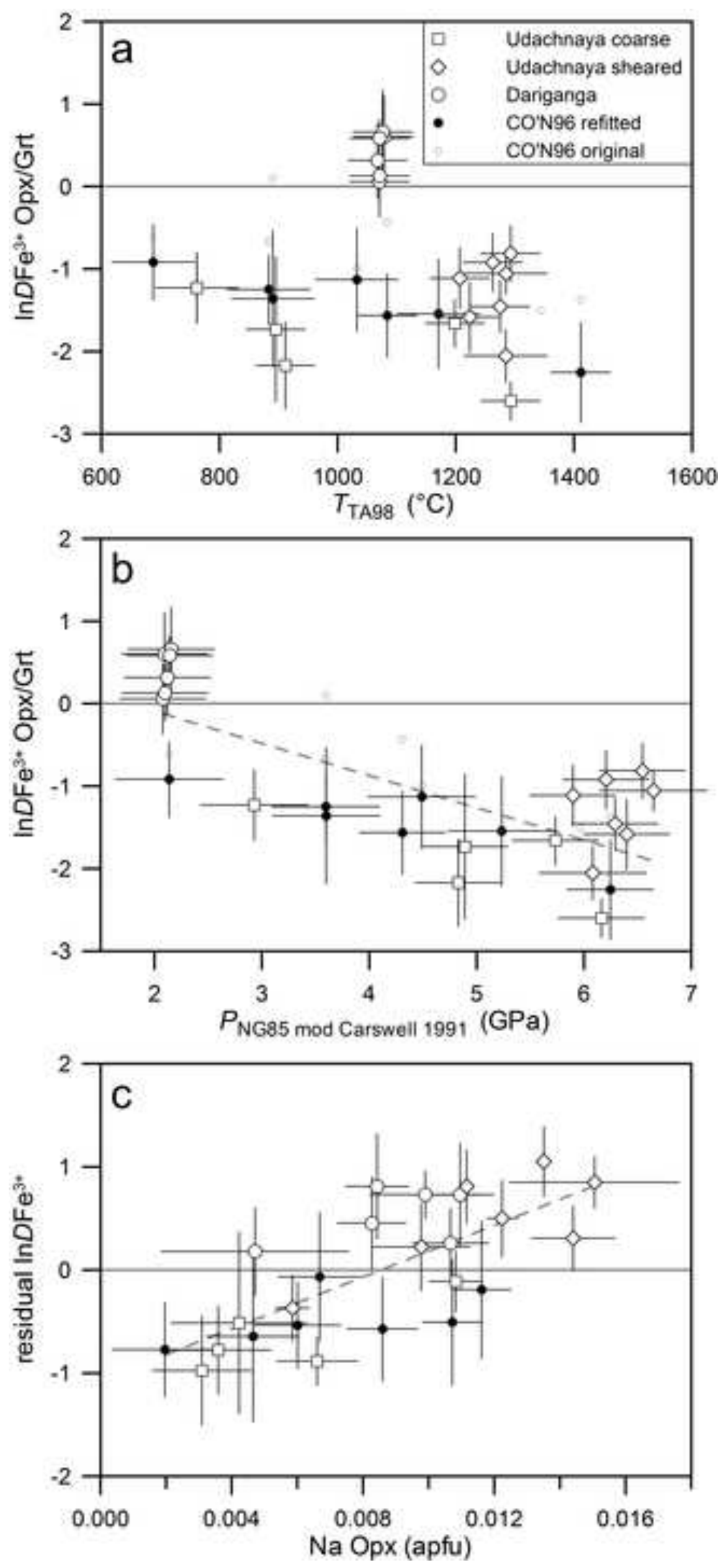

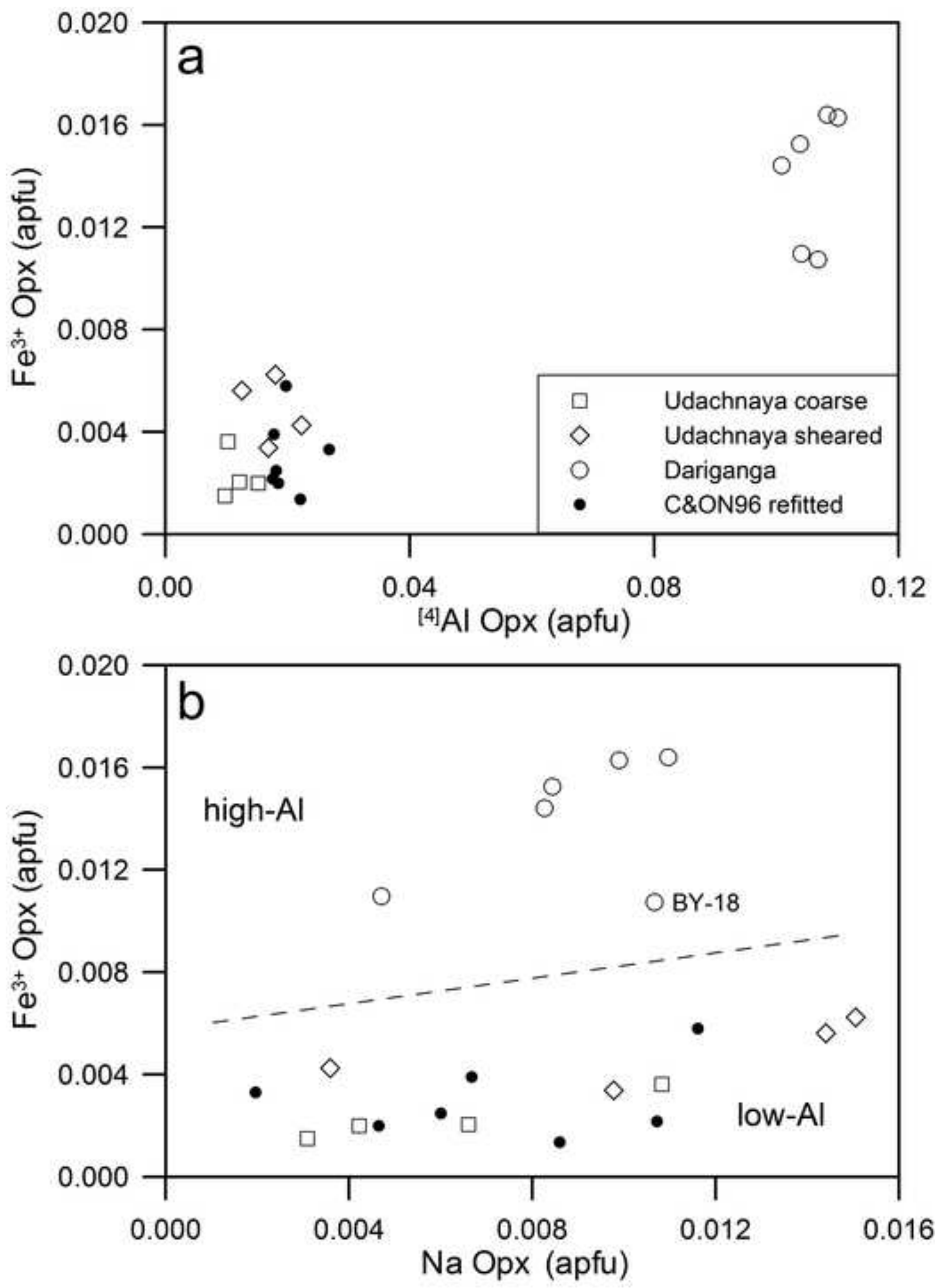

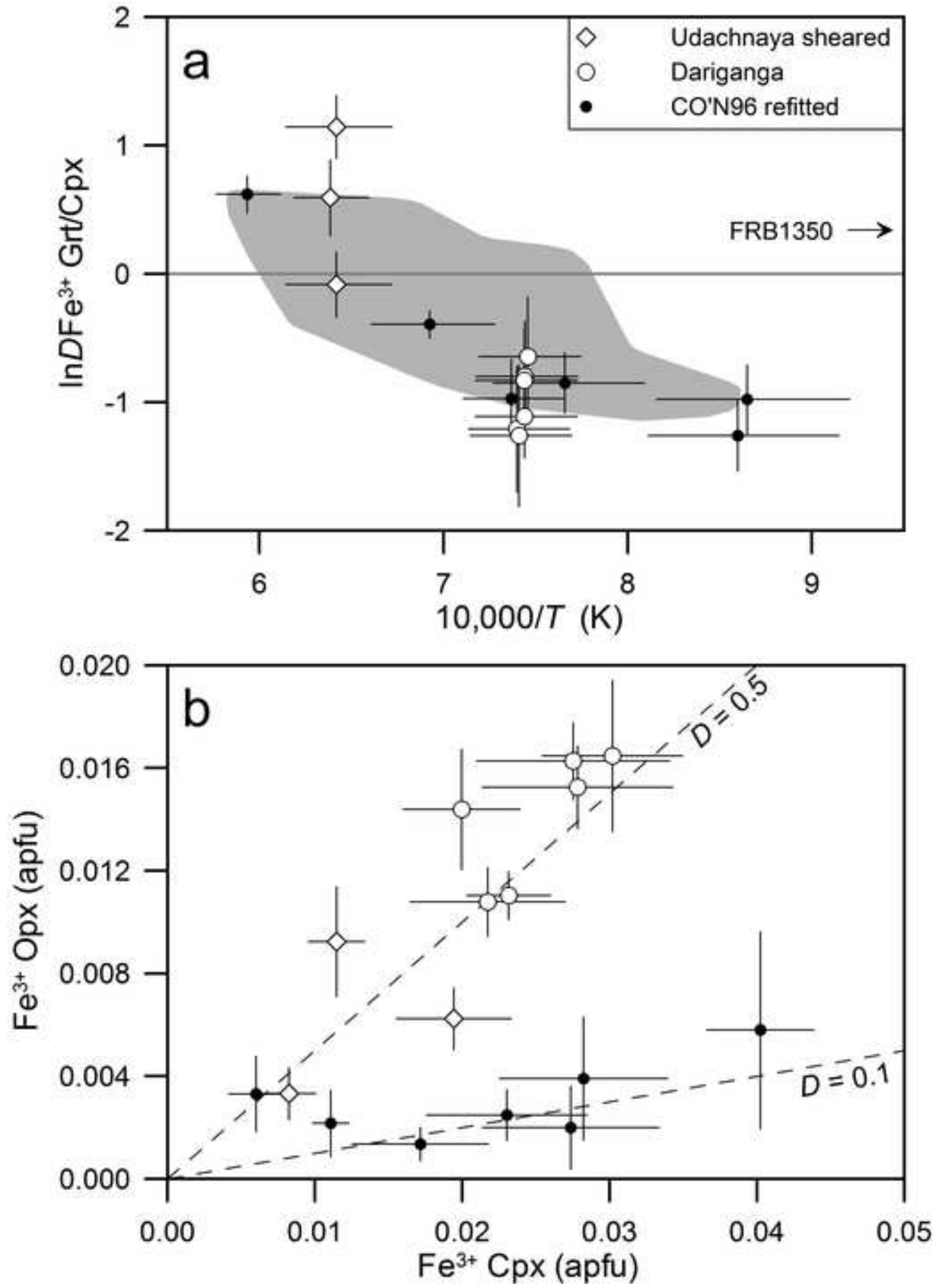


\section{Figure 6}

Click here to download high resolution image

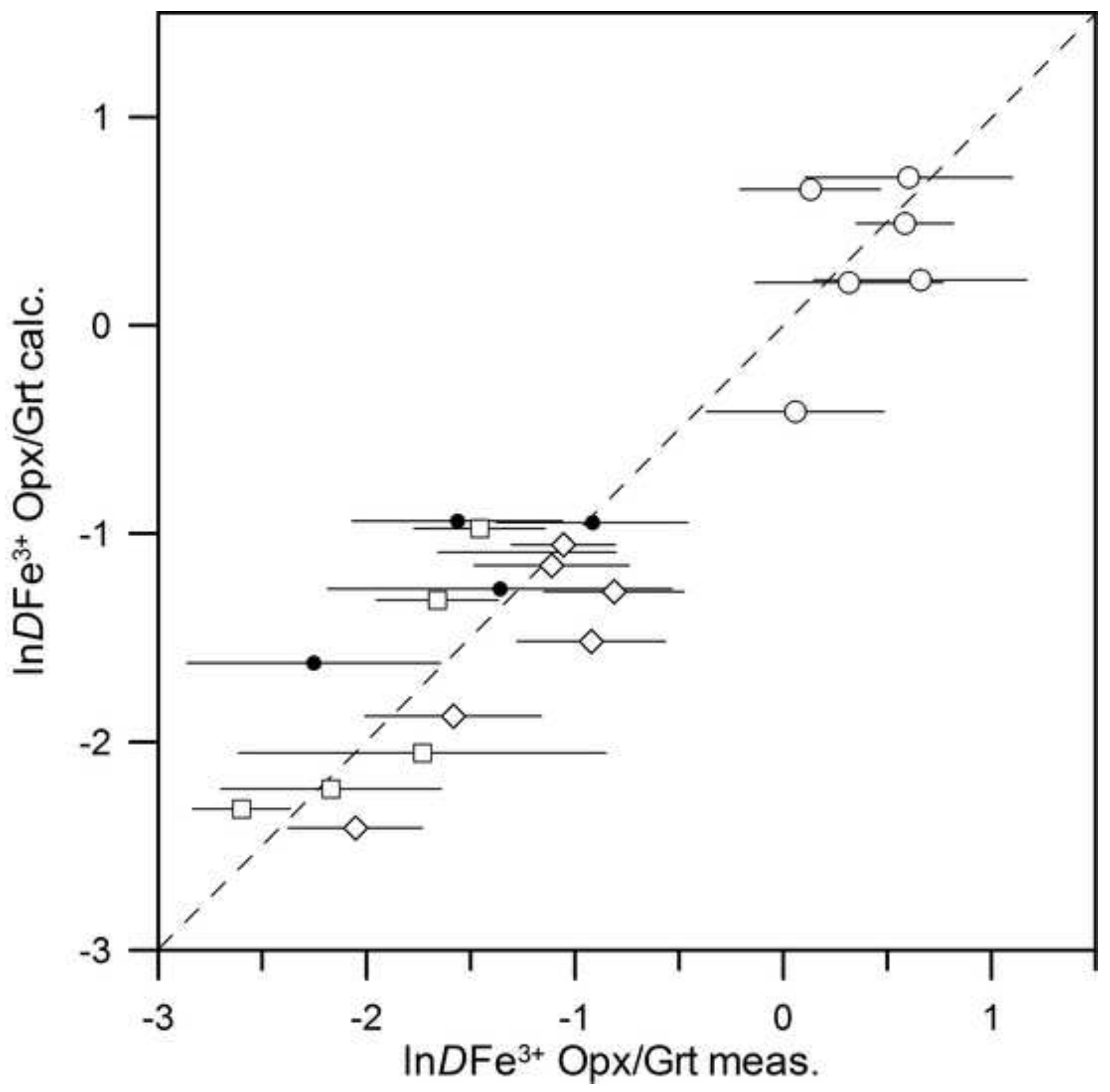




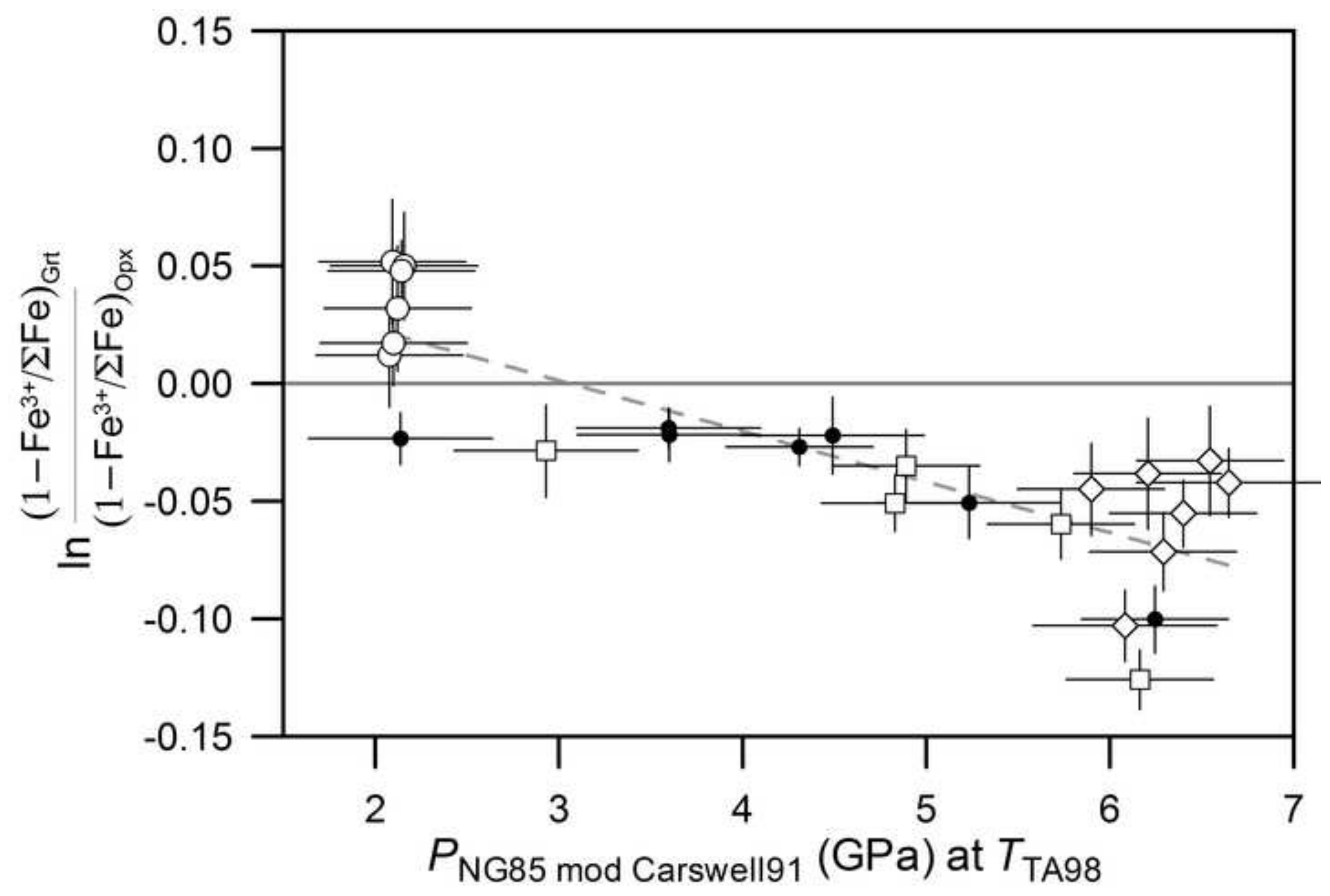




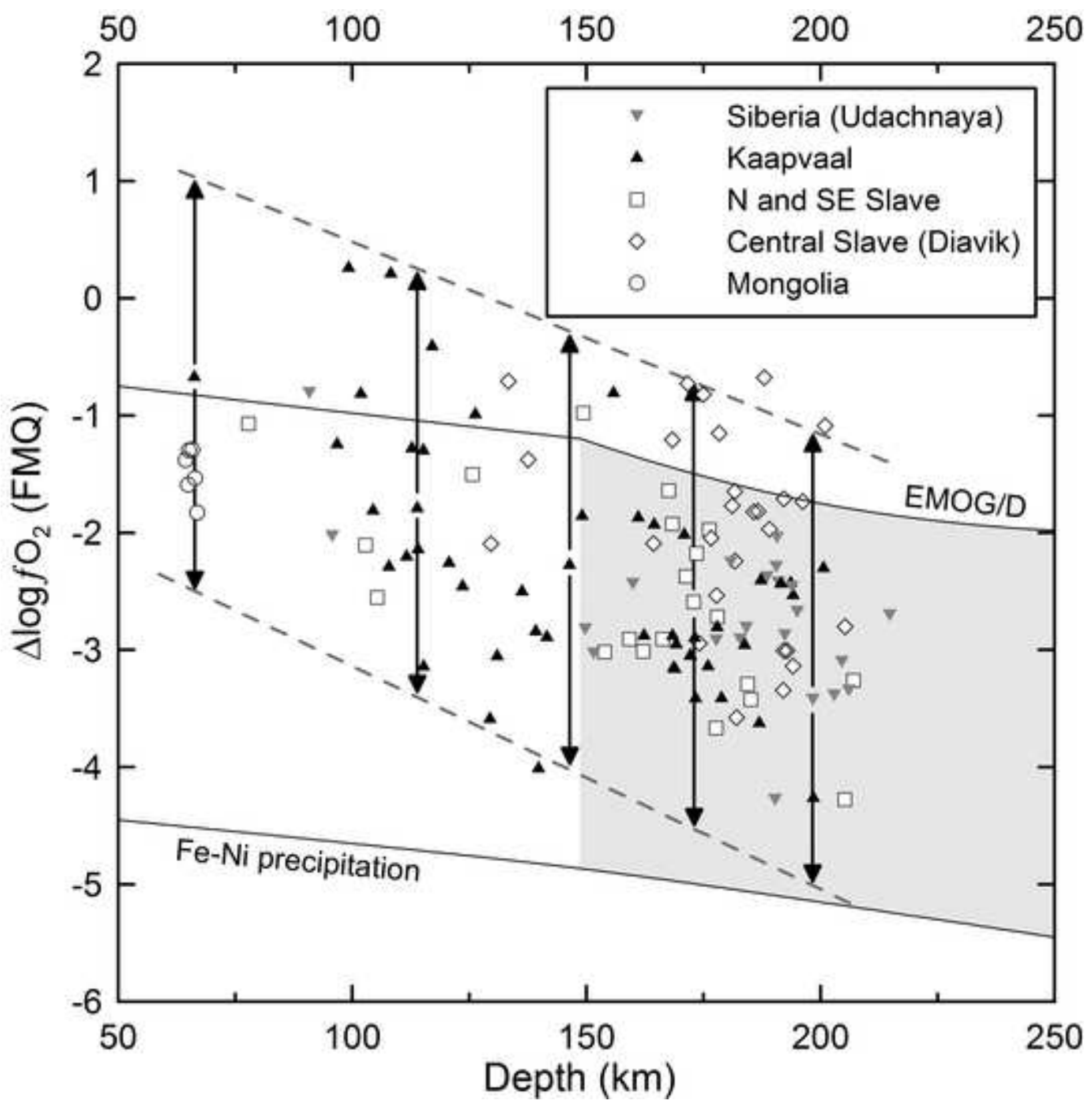




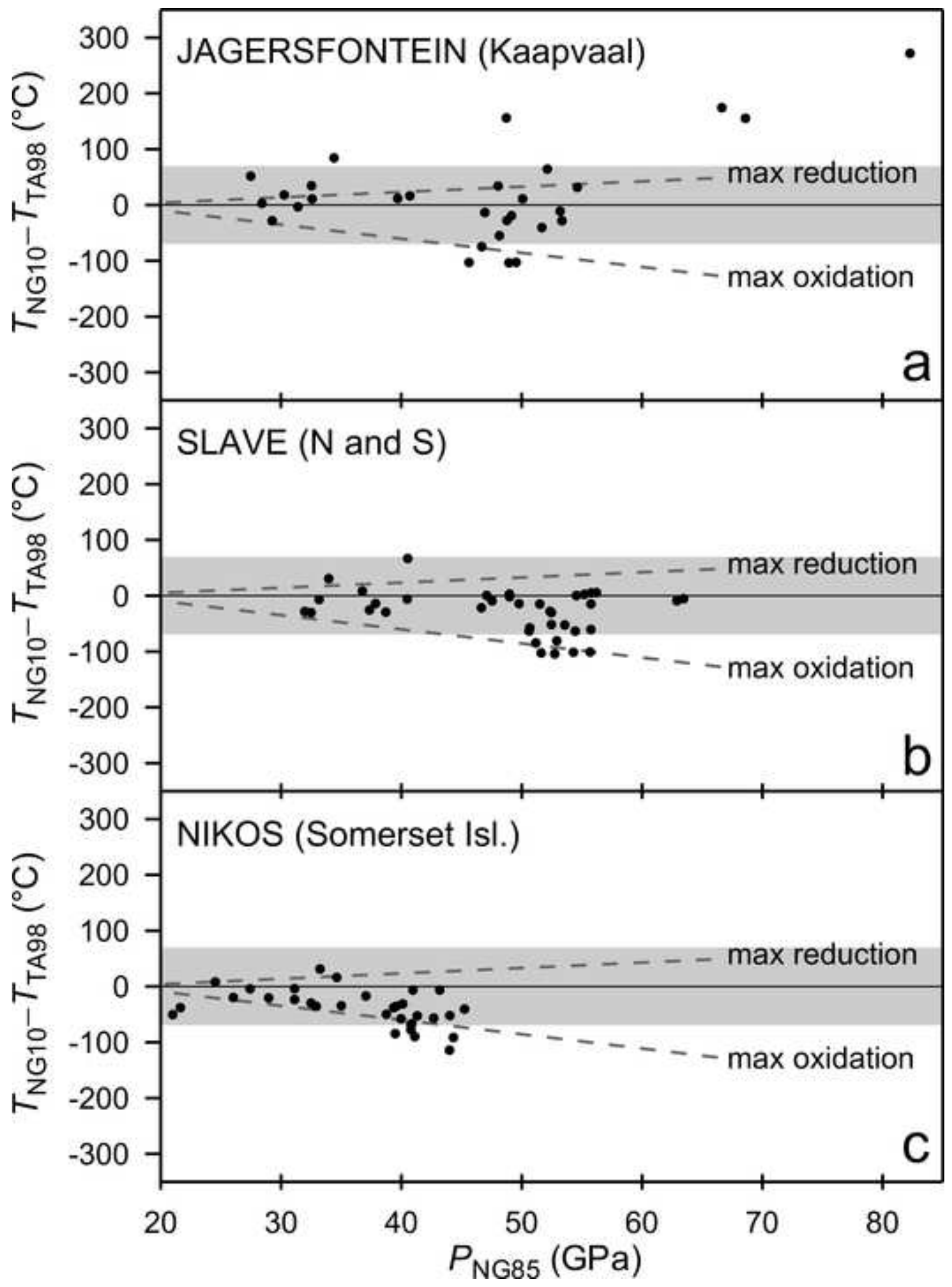


Table 1. Modal compositions, selected chemical data and thermobarometric estimates for the investigated xenoliths.

\begin{tabular}{|c|c|c|c|c|c|c|c|c|c|c|c|c|c|c|c|}
\hline Sample & Rock type & \multicolumn{3}{|c|}{ Modal composition, wt $\%$} & Grt & Spl & $\begin{array}{l}\text { Mg\# } \\
\text { WR }\end{array}$ & $\begin{array}{c}\mathrm{Al}_{2} \mathrm{O}_{3} \\
\text { WR }\end{array}$ & \multicolumn{5}{|c|}{ Thermobarometry } & $\begin{array}{l}P(\mathrm{GPa}) \\
\text { Ca91 at } \\
\text { TTA98 }\end{array}$ & $\begin{array}{c}T\left({ }^{\circ} \mathrm{C}\right) \\
\text { TA98 at } \\
\text { PCa91 }\end{array}$ \\
\hline \multicolumn{16}{|c|}{ Udachnaya coarse and "transitional" } \\
\hline U64 & Harzburgite & 77 & 17 & 3.8 & 2.5 & 0.0 & 0.910 & 0.50 & 5.62 & 1194 & 1183 & 1149 & 1129 & 5.73 & 1198 \\
\hline U283 & Harzburgite & 85 & 10 & 1.4 & 3.7 & 0.2 & 0.920 & 0.91 & 2.93 & 762 & 747 & 827 & 763 & 2.93 & 762 \\
\hline U501 & Harzburgite & 82 & 6.6 & 4.3 & 6.7 & 0.0 & 0.913 & 1.43 & 4.89 & 895 & 872 & 913 & 945 & 4.89 & 895 \\
\hline \multicolumn{16}{|c|}{ Udachnaya sheared } \\
\hline U70 & Lherzolite & 79 & 9.5 & 6.0 & 5.5 & 0.0 & 0.904 & 1.21 & 5.14 & 1233 & 1234 & 1219 & 1188 & 6.29 & 1275 \\
\hline U183 & Harzburgite & 81 & 14 & 1.9 & 3.8 & 0.0 & 0.919 & 0.77 & 6.40 & 1224 & 1205 & 1218 & 1237 & 6.40 & 1224 \\
\hline U267 & Lherzolite & 53 & 22 & 12 & 13 & 0.0 & 0.896 & 3.17 & 5.88 & 1257 & 1242 & 1265 & 1353 & 6.65 & 1285 \\
\hline Y-10 & Lherzolite & 71 & 16 & 6.0 & 7.0 & 0.0 & 0.905 & 1.59 & 5.87 & 1206 & 1192 & 1202 & 1262 & 5.90 & 1207 \\
\hline Y-19 & Wehrlite & 80 & 1.0 & 16 & 3.7 & 0.0 & 0.905 & 1.50 & 5.85 & 1249 & 1242 & 1239 & 1210 & 6.21 & 1262 \\
\hline $8508-9$ & Lherzolite & 57 & 27 & 13 & 3.5 & 0.0 & 0.897 & 2.67 & 2.16 & 1076 & 1054 & 1104 & 1108 & 2.16 & 1076 \\
\hline BY-18 & Lherzolite & 57 & 19 & 13 & 11 & 0.3 & 0.903 & 3.94 & 2.10 & 1071 & 1048 & 1116 & 1102 & 2.10 & 1071 \\
\hline BY-19 & Lherzolite & 59 & 21 & 10 & 9.3 & 0.0 & 0.894 & 3.71 & 2.14 & 1071 & 1049 & 1107 & 1123 & 2.14 & 1071 \\
\hline BY-27 & Lherzolite & 56 & 26 & 12 & 6.5 & 0.0 & 0.892 & 3.41 & 2.09 & 1078 & 1057 & 1112 & 1070 & 2.09 & 1078 \\
\hline BY-33 & Lherzolite & 54 & 27 & 9.7 & 8.9 & 0.0 & 0.896 & 3.79 & 2.12 & 1068 & 1047 & 1093 & 1096 & 2.12 & 1068 \\
\hline
\end{tabular}

Modal abundances obtained by least-squares method from whole-rock and mineral analyses (data for Udachnaya after Ionov et al. 2010 and Goncharov et al. 2012; data for samples 87/70 and 87/97 not available due to small xenolith size). Ol - olivine, Opx - orthopyroxene, Cpx - clinopyroxene, Grt - garnet, Spl - spinel, WR whole rock. Thermobarometer labels: PNG85 - Nickel and Green (1985); PCa91 - Nickel and Green (1985), with correction in Carswell (1991); TTA98 - Taylor (1998); TNT00 - Nimis and Taylor (2000); TCa-in-Opx - Brey and Köhler (1990), with correction in Nimis and Grütter (2010); TNG10 - Nimis and Grütter (2010). 
Table 2. Electron microprobe analyses (wt $\%$ ) of minerals and $P-T$ estimates.

\begin{tabular}{|c|c|c|c|c|c|c|c|c|c|c|c|c|c|c|c|}
\hline Sample & Mineral & $\mathrm{SiO}_{2}$ & $\mathrm{TiO}_{2}$ & $\mathrm{Al}_{2} \mathrm{O}_{3}$ & $\mathrm{Cr}_{2} \mathrm{O}_{3}$ & FeOtot & $\mathrm{FeO}$ & $\mathrm{Fe}_{2} \mathrm{O}_{3}$ & $\mathrm{MnO}$ & $\mathrm{NiO}$ & $\mathrm{MgO}$ & $\mathrm{CaO}$ & $\mathrm{Na}_{2} \mathrm{O}$ & $\mathrm{K}_{2} \mathrm{O}$ & Tot \\
\hline \multicolumn{16}{|c|}{$\begin{array}{l}\text { Udachnaya coarse } \\
\text { and transitional }\end{array}$} \\
\hline \multirow[t]{4}{*}{ U29 } & ol & 41.56 & $<0.10$ & $<0.06$ & $<0.12$ & 7.59 & & & 0.10 & 0.37 & 50.53 & $<0.07$ & $<0.05$ & $<0.05$ & 100.11 \\
\hline & opx & 58.63 & $<0.10$ & 0.37 & 0.22 & 4.37 & 4.31 & 0.06 & 0.10 & 0.10 & 35.95 & 0.35 & 0.05 & $<0.05$ & 100.13 \\
\hline & cpx & 54.47 & $<0.10$ & 1.78 & 2.10 & 2.10 & & & 0.09 & $<0.06$ & 16.20 & 20.71 & 1.73 & $<0.05$ & 99.18 \\
\hline & grt & 41.49 & $<0.10$ & 19.17 & 6.57 & 7.37 & 6.94 & 0.48 & 0.46 & $<0.06$ & 18.95 & 6.49 & $<0.05$ & $<0.05$ & 100.50 \\
\hline \multirow[t]{4}{*}{ U64 } & ol & 41.06 & $<0.10$ & $<0.06$ & $<0.12$ & 8.87 & & & 0.11 & 0.31 & 49.50 & $<0.07$ & $<0.05$ & $<0.05$ & 99.91 \\
\hline & opx & 58.29 & $<0.10$ & 0.43 & 0.38 & 5.14 & 5.02 & 0.14 & 0.13 & 0.13 & 34.84 & 0.65 & 0.16 & $<0.05$ & 100.16 \\
\hline & cpx & 55.12 & 0.18 & 1.43 & 2.47 & 2.96 & & & 0.11 & 0.06 & 17.66 & 17.97 & 1.90 & 0.05 & 99.90 \\
\hline & grt & 40.74 & 0.13 & 14.86 & 11.27 & 7.63 & 7.01 & 0.69 & 0.40 & $<0.06$ & 18.75 & 6.30 & 0.06 & $<0.05$ & 100.14 \\
\hline \multirow[t]{5}{*}{ U283 } & ol & 41.40 & $<0.10$ & $<0.06$ & $<0.12$ & 7.82 & & & 0.10 & 0.36 & 50.27 & $<0.07$ & $<0.05$ & $<0.05$ & 99.91 \\
\hline & opx & 58.33 & $<0.10$ & 0.87 & 0.33 & 4.86 & 4.71 & 0.17 & 0.12 & 0.08 & 35.59 & 0.31 & 0.05 & $<0.05$ & 100.55 \\
\hline & cpx & 55.12 & $<0.10$ & 2.09 & 1.84 & 1.37 & & & 0.09 & $<0.06$ & 16.19 & 21.67 & 1.67 & $<0.05$ & 100.05 \\
\hline & grt & 41.27 & $<0.10$ & 20.28 & 5.16 & 8.36 & 7.88 & 0.54 & 0.58 & $<0.06$ & 18.84 & 6.30 & $<0.05$ & $<0.05$ & 100.79 \\
\hline & spl & 0.00 & $<0.10$ & 15.52 & 55.17 & 16.74 & 0.39 & 0.02 & 11.72 & $<0.06$ & 0.00 & 0.00 & 99.63 & & \\
\hline \multirow[t]{4}{*}{ U501 } & ol & 41.46 & $<0.10$ & $<0.06$ & $<0.12$ & 8.16 & & & 0.09 & 0.34 & 50.27 & $<0.07$ & $<0.05$ & $<0.05$ & 100.33 \\
\hline & opx & 58.60 & 0.10 & 0.48 & 0.30 & 5.00 & 4.93 & 0.08 & 0.10 & 0.06 & 35.63 & 0.29 & 0.06 & $<0.05$ & 100.62 \\
\hline & $\mathrm{cpx}$ & 55.16 & 0.18 & 2.21 & 2.52 & 2.03 & & & 0.09 & $<0.06$ & 15.65 & 20.11 & 2.23 & $<0.05$ & 100.17 \\
\hline & grt & 41.71 & 0.26 & 19.47 & 5.45 & 8.54 & 8.17 & 0.42 & 0.50 & $<0.06$ & 19.34 & 5.47 & 0.06 & $<0.05$ & 100.79 \\
\hline \multirow{4}{*}{$\begin{array}{l}\text { U10 } \\
\text { (transit.) }\end{array}$} & ol & 41.18 & $<0.10$ & $<0.06$ & $<0.12$ & 8.68 & & & 0.12 & 0.35 & 49.62 & $<0.07$ & $<0.05$ & $<0.05$ & 100.15 \\
\hline & opx & 58.14 & $<0.10$ & 0.49 & 0.34 & 5.08 & 5.00 & 0.08 & 0.10 & 0.10 & 34.78 & 1.00 & 0.10 & $<0.05$ & 100.12 \\
\hline & $\operatorname{cpx}$ & 55.16 & $<0.10$ & 0.80 & 1.05 & 2.78 & & & 0.12 & 0.07 & 19.26 & 19.24 & 0.74 & 0.09 & 99.32 \\
\hline & grt & 41.12 & 0.45 & 15.55 & 9.54 & 7.06 & 6.16 & 1.00 & 0.30 & $<0.06$ & 19.11 & 6.73 & $<0.05$ & $<0.05$ & 99.86 \\
\hline \multicolumn{16}{|c|}{ Udachnaya sheared } \\
\hline \multirow[t]{4}{*}{ U70 } & ol & 41.34 & $<0.10$ & $<0.06$ & $<0.12$ & 9.52 & & & 0.09 & 0.38 & 48.88 & $<0.07$ & $<0.05$ & $<0.05$ & 100.33 \\
\hline & opx & 58.33 & $<0.10$ & 0.65 & 0.27 & 5.67 & 5.47 & 0.22 & 0.12 & n.a. & 34.03 & 0.92 & 0.22 & n.a. & 100.21 \\
\hline & cpx & 55.48 & 0.14 & 1.71 & 1.25 & 3.56 & & & 0.11 & n.a. & 18.45 & 17.67 & 1.65 & $<0.05$ & 100.02 \\
\hline & grt & 42.31 & 0.49 & 19.00 & 5.00 & 8.00 & 7.19 & 0.90 & 0.31 & n.a. & 20.69 & 4.88 & 0.06 & n.a. & 100.75 \\
\hline \multirow[t]{4}{*}{ U183 } & ol & 41.16 & $<0.10$ & $<0.06$ & $<0.12$ & 8.21 & & & 0.14 & 0.38 & 49.80 & $<0.07$ & $<0.05$ & $<0.05$ & 99.9 \\
\hline & opx & 57.96 & 0.18 & 0.53 & 0.34 & 4.79 & 4.67 & 0.13 & 0.10 & 0.08 & 35.04 & 0.74 & 0.15 & $<0.05$ & 99.92 \\
\hline & cpx & 54.90 & 0.33 & 1.33 & 1.52 & 2.82 & & & 0.11 & 0.06 & 18.04 & 18.63 & 1.53 & $<0.05$ & 99.29 \\
\hline & grt & 41.05 & 0.27 & 16.47 & 9.22 & 7.04 & 6.49 & 0.60 & 0.34 & $<0.06$ & 19.28 & 6.56 & $<0.05$ & $<0.05$ & 100.22 \\
\hline \multirow[t]{4}{*}{ U267 } & ol & 41.10 & $<0.10$ & $<0.06$ & $<0.12$ & 9.94 & & & 0.12 & 0.32 & 48.75 & $<0.07$ & $<0.05$ & $<0.05$ & 100.51 \\
\hline & opx & 57.90 & 0.22 & 0.69 & 0.21 & 5.97 & 5.75 & 0.24 & 0.13 & 0.13 & 33.91 & 0.96 & 0.23 & $<0.05$ & 100.34 \\
\hline & cpx & 55.23 & 0.33 & 1.85 & 0.69 & 3.68 & 3.03 & 0.72 & 0.10 & 0.07 & 18.53 & 17.83 & 1.54 & 0.06 & 99.91 \\
\hline & grt & 42.49 & 0.43 & 21.03 & 2.63 & 7.97 & 7.36 & 0.67 & 0.24 & $<0.06$ & 21.43 & 4.37 & $<0.05$ & $<0.05$ & 100.59 \\
\hline \multirow[t]{4}{*}{ Y-10 } & ol & 40.65 & n.a. & n.a. & n.a. & 9.1 & & & 0.10 & 0.51 & 49.87 & n.a. & n.a. & n.a. & 100.23 \\
\hline & opx & 58.40 & 0.21 & 0.60 & 0.25 & 5.44 & 5.23 & 0.23 & 0.13 & n.a. & 34.84 & 0.77 & 0.19 & n.a. & 100.83 \\
\hline & cpx & 55.44 & 0.31 & 1.37 & 1.15 & 3.02 & & & 0.10 & n.a. & 18.43 & 19.14 & 1.41 & n.a. & 100.37 \\
\hline & grt & 41.73 & 0.37 & 18.94 & 5.64 & 7.54 & 6.93 & 0.68 & 0.37 & 0.01 & 20.32 & 5.42 & 0.04 & n.a. & 100.36 \\
\hline \multirow[t]{2}{*}{ Y-19 } & ol & 41.01 & 0.04 & 0.01 & n.a. & 8.74 & & & 0.11 & 0.40 & 50.72 & 0.04 & 0.01 & n.a. & 101.08 \\
\hline & opx & 57.31 & 0.11 & 0.60 & 0.25 & 5.31 & 5.04 & 0.30 & 0.12 & n.a. & 35.89 & 0.88 & 0.17 & n.a. & 100.64 \\
\hline
\end{tabular}




\begin{tabular}{|c|c|c|c|c|c|c|c|c|c|c|c|c|c|c|c|}
\hline & cpx & 54.86 & 0.18 & 1.53 & 1.05 & 3.20 & & & 0.11 & n.a. & 19.10 & 18.31 & 1.40 & n.a. & 99.75 \\
\hline & grt & 41.99 & 0.19 & 19.77 & 4.94 & 7.48 & 6.83 & 0.72 & 0.32 & n.a. & 20.42 & 4.94 & 0.03 & n.a. & 100.07 \\
\hline \multirow[t]{4}{*}{$87-70$} & ol & 41.10 & 0.02 & 0.00 & n.a. & 8.37 & & & 0.11 & 0.40 & 51.12 & 0.05 & 0.00 & n.a. & 101.17 \\
\hline & opx & 57.87 & 0.02 & 0.53 & 0.27 & 4.95 & 4.83 & 0.13 & 0.14 & n.a. & 35.47 & 0.94 & 0.09 & n.a. & 100.28 \\
\hline & cpx & 55.04 & 0.01 & 0.89 & 0.81 & 2.95 & 2.67 & 0.31 & 0.11 & n.a. & 20.12 & 19.39 & 0.76 & n.a. & 100.08 \\
\hline & grt & 41.46 & 0.05 & 17.44 & 7.93 & 7.19 & 6.33 & 0.95 & 0.32 & n.a. & 19.50 & 6.30 & 0.01 & n.a. & 100.19 \\
\hline \multirow[t]{4}{*}{$87-97$} & ol & 40.42 & 0.04 & 0.02 & n.a. & 11.40 & & & 0.11 & 0.36 & 49.00 & 0.04 & 0.02 & n.a. & 101.40 \\
\hline & opx & 57.16 & 0.18 & 0.66 & 0.17 & 6.79 & 6.46 & 0.36 & 0.12 & n.a. & 34.13 & 0.93 & 0.20 & n.a. & 100.34 \\
\hline & $\mathrm{cpx}$ & 54.55 & 0.32 & 1.85 & 0.71 & 4.45 & 4.07 & 0.42 & 0.13 & n.a. & 18.88 & 17.15 & 1.62 & n.a. & 99.66 \\
\hline & grt & 41.75 & 0.45 & 20.19 & 4.21 & 8.90 & 8.20 & 0.77 & 0.32 & n.a. & 19.60 & 4.99 & 0.06 & n.a. & 100.47 \\
\hline \multicolumn{16}{|c|}{ Dariganga coarse } \\
\hline \multirow[t]{4}{*}{$8508-6$} & ol & 40.30 & n.a. & n.a. & n.a. & 10.09 & & & 0.21 & 0.42 & 48.76 & n.a. & n.a. & n.a. & 99.77 \\
\hline & opx & 54.34 & $<0.10$ & 4.44 & 0.74 & 6.40 & 6.02 & 0.42 & 0.11 & n.a. & 32.50 & 0.97 & 0.07 & n.a. & 99.58 \\
\hline & cpx & 52.36 & 0.20 & 5.60 & 1.38 & 3.36 & 2.59 & 0.85 & 0.00 & n.a. & 16.13 & 19.54 & 1.39 & n.a. & 99.94 \\
\hline & grt & 41.74 & 0.12 & 22.78 & 1.60 & 7.32 & 6.97 & 0.39 & 0.25 & n.a. & 20.71 & 5.35 & n.a. & n.a. & 99.87 \\
\hline \multirow[t]{4}{*}{$8508-9$} & ol & 40.62 & $<0.10$ & 0.08 & 0.02 & 9.71 & & & 0.12 & 0.38 & 49.20 & 0.09 & $<0.05$ & $<0.05$ & 100.23 \\
\hline & opx & 54.55 & 0.11 & 4.35 & 0.65 & 6.20 & 5.67 & 0.59 & 0.12 & 0.11 & 32.59 & 1.05 & 0.13 & $<0.05$ & 99.88 \\
\hline & $\mathrm{cpx}$ & 51.91 & 0.30 & 5.32 & 1.05 & 3.33 & 2.41 & 1.02 & 0.09 & $<0.06$ & 16.48 & 19.34 & 1.38 & $<0.05$ & 99.27 \\
\hline & grt & 42.04 & 0.12 & 22.70 & 1.28 & 7.00 & 6.74 & 0.30 & 0.28 & $<0.06$ & 20.77 & 5.42 & $<0.05$ & $<0.05$ & 99.65 \\
\hline \multirow[t]{5}{*}{ BY-18 } & ol & 40.87 & $<0.10$ & 0.04 & 0.00 & 9.09 & & & 0.13 & 0.41 & 50.00 & 0.08 & $<0.05$ & $<0.05$ & 100.64 \\
\hline & opx & 54.75 & 0.16 & 4.61 & 0.71 & 5.85 & 5.47 & 0.42 & 0.11 & 0.14 & 32.97 & 1.12 & 0.16 & $<0.05$ & 100.58 \\
\hline & $\mathrm{cpx}$ & 51.93 & 0.49 & 5.94 & 1.27 & 3.25 & 2.53 & 0.80 & 0.05 & $<0.06$ & 16.46 & 19.16 & 1.57 & $<0.05$ & 100.15 \\
\hline & grt & 42.17 & 0.20 & 22.59 & 1.67 & 6.72 & 6.40 & 0.36 & 0.30 & $<0.06$ & 21.53 & 5.30 & $<0.05$ & $<0.05$ & 100.53 \\
\hline & spl & 0.11 & 0.40 & 43.73 & 21.76 & 13.05 & & & $<0.06$ & 0.32 & 18.92 & 0.01 & $<0.05$ & $<0.05$ & 98.30 \\
\hline \multirow[t]{4}{*}{ BY-19 } & ol & 40.66 & $<0.10$ & $<0.06$ & $<0.12$ & 10.01 & & & 0.13 & 0.39 & 49.36 & 0.08 & $<0.05$ & $<0.05$ & 100.70 \\
\hline & opx & 54.80 & 0.23 & 4.54 & 0.67 & 6.53 & 5.96 & 0.63 & 0.10 & 0.10 & 32.68 & 1.07 & 0.15 & $<0.05$ & 100.88 \\
\hline & cpx & 51.93 & 0.68 & 5.94 & 1.25 & 3.49 & 2.58 & 1.01 & 0.06 & 0.06 & 16.08 & 18.95 & 1.59 & $<0.05$ & 100.04 \\
\hline & grt & 42.11 & 0.25 & 22.61 & 1.43 & 7.34 & 7.04 & 0.34 & 0.31 & $<0.06$ & 21.18 & 5.32 & $<0.05$ & $<0.05$ & 100.63 \\
\hline \multirow[t]{4}{*}{ BY-27 } & ol & 40.57 & $<0.10$ & $<0.06$ & $<0.12$ & 10.11 & & & 0.20 & 0.31 & 49.62 & 0.09 & $<0.05$ & $<0.05$ & 101.03 \\
\hline & opx & 54.70 & 0.18 & 4.63 & 0.53 & 6.41 & 5.84 & 0.63 & 0.16 & 0.09 & 32.64 & 1.10 & 0.16 & $<0.05$ & 100.62 \\
\hline & $\mathrm{cpx}$ & 52.18 & 0.51 & 6.08 & 0.91 & 3.54 & 2.54 & 1.12 & 0.08 & 0.07 & 16.37 & 18.78 & 1.69 & $<0.05$ & 100.20 \\
\hline & grt & 42.17 & 0.22 & 22.79 & 1.38 & 7.48 & 7.18 & 0.34 & 0.31 & $<0.06$ & 20.99 & 5.29 & $<0.05$ & $<0.05$ & 100.71 \\
\hline \multirow[t]{4}{*}{ BY-33 } & ol & 40.80 & $<0.10$ & 0.06 & $<0.12$ & 9.75 & & & 0.15 & 0.31 & 49.29 & 0.07 & $<0.05$ & $<0.05$ & 100.44 \\
\hline & opx & 55.03 & 0.09 & 4.32 & 0.62 & 6.29 & 5.78 & 0.56 & 0.13 & 0.09 & 33.08 & 1.03 & 0.12 & $<0.05$ & 100.80 \\
\hline & cpx & 52.25 & 0.27 & 5.40 & 1.24 & 3.12 & 2.45 & 0.73 & 0.09 & 0.06 & 16.45 & 19.57 & 1.39 & $<0.05$ & 99.84 \\
\hline & grt & 42.20 & 0.17 & 22.58 & 1.54 & 7.12 & 6.77 & 0.40 & 0.25 & $<0.06$ & 21.05 & 5.45 & $<0.05$ & $<0.05$ & 100.43 \\
\hline
\end{tabular}

n.a. - not analyzed. 
Table 3

Click here to download Table: Table3_GAG.doc

Table 3. Mössbauer hyperfine parameters $(\mathrm{mm} / \mathrm{s})$ and $\mathrm{Fe}^{2+}$ and $\mathrm{Fe}^{3+}$ percentages for orthopyroxenes

\begin{tabular}{|c|c|c|c|c|c|c|c|c|c|c|c|c|c|c|}
\hline \multirow{2}{*}{ Sample } & \multicolumn{4}{|c|}{$\mathrm{Fe}^{2+} \mathrm{I}$} & \multicolumn{4}{|c|}{$\mathrm{Fe}^{2+} \mathrm{II}$} & \multicolumn{4}{|c|}{$\mathrm{Fe}^{3+}$} & \multirow{2}{*}{$\mathrm{Fe}^{3+} / \Sigma \mathrm{Fe}$} & \multirow{2}{*}{ err } \\
\hline & QS & IS & HW & $\%$ & QS & IS & HW & $\%$ & QS & IS & HW & $\%$ & & \\
\hline \multicolumn{15}{|c|}{ Udachnaya coarse } \\
\hline U29 & 2.23 & 1.15 & 0.28 & 86.7 & 2.08 & 1.13 & 0.27 & 12.2 & 0.70 & 0.44 & 0.23 & 1.2 & 0.012 & 0.007 \\
\hline U64 & 2.24 & 1.16 & 0.27 & 29.1 & 2.10 & 1.15 & 0.29 & 68.4 & 0.79 & 0.45 & 0.31 & 2.5 & 0.025 & 0.006 \\
\hline U283 & 2.26 & 1.17 & 0.26 & 19.2 & 2.11 & 1.15 & 0.25 & 77.7 & 0.78 & 0.44 & 0.29 & 3.1 & 0.031 & 0.010 \\
\hline U501 & 2.31 & 1.16 & 0.29 & 16.2 & 2.10 & 1.16 & 0.27 & 82.5 & 0.80 & 0.50 & 0.26 & 1.4 & 0.014 & 0.012 \\
\hline \multicolumn{15}{|c|}{ Udachnaya sheared } \\
\hline U10 & 2.19 & 1.16 & 0.29 & 72.5 & 2.01 & 1.15 & 0.29 & 26.1 & 0.77 & 0.46 & 0.29 & 1.4 & 0.014 & 0.003 \\
\hline U70 & 2.26 & 1.17 & 0.30 & 36.0 & 2.08 & 1.13 & 0.29 & 60.6 & 0.75 & 0.44 & 0.31 & 3.4 & 0.034 & 0.010 \\
\hline U183 & 2.23 & 1.13 & 0.29 & 13.0 & 2.11 & 1.15 & 0.28 & 84.5 & 0.69 & 0.45 & 0.30 & 2.5 & 0.025 & 0.010 \\
\hline U267 & 2.31 & 1.21 & 0.31 & 12.3 & 2.10 & 1.15 & 0.28 & 84.2 & 0.75 & 0.45 & 0.24 & 3.6 & 0.036 & 0.007 \\
\hline$Y-10$ & 2.18 & 1.16 & 0.40 & 36.3 & 2.08 & 1.14 & 0.26 & 59.8 & 0.81 & 0.49 & 0.30 & 3.9 & 0.039 & 0.013 \\
\hline Y-19 & 2.30 & 1.20 & 0.29 & 17.5 & 2.10 & 1.15 & 0.27 & 77.5 & 0.77 & 0.48 & 0.33 & 5.1 & 0.051 & 0.017 \\
\hline $87-70$ & 2.22 & 1.19 & 0.44 & 22.6 & 2.08 & 1.19 & 0.30 & 75.1 & 0.71 & 0.50 & 0.27 & 2.4 & 0.024 & 0.007 \\
\hline $87-97$ & 2.27 & 1.14 & 0.45 & 11.1 & 2.09 & 1.19 & 0.35 & 84.2 & 0.77 & 0.49 & 0.45 & 4.7 & 0.047 & 0.011 \\
\hline \multicolumn{15}{|c|}{ Dariganga coarse } \\
\hline $8508-6$ & 2.19 & 1.16 & 0.40 & 76.2 & 1.99 & 1.10 & 0.34 & 17.9 & 0.65 & 0.51 & 0.25 & 5.9 & 0.059 & 0.005 \\
\hline $8508-9$ & 2.18 & 1.17 & 0.40 & 62.9 & 2.02 & 1.10 & 0.36 & 28.6 & 0.79 & 0.43 & 0.37 & 8.5 & 0.085 & 0.009 \\
\hline BY-18 & 2.24 & 1.22 & 0.41 & 19.3 & 2.12 & 1.12 & 0.40 & 74.3 & 0.74 & 0.43 & 0.30 & 6.4 & 0.064 & 0.009 \\
\hline BY-19 & 2.19 & 1.16 & 0.39 & 73.6 & 1.99 & 1.12 & 0.31 & 17.8 & 0.77 & 0.46 & 0.29 & 8.7 & 0.087 & 0.008 \\
\hline BY-27 & 2.20 & 1.16 & 0.39 & 69.3 & 1.98 & 1.12 & 0.31 & 21.8 & 0.79 & 0.42 & 0.28 & 8.9 & 0.089 & 0.016 \\
\hline BY-33 & 2.19 & 1.20 & 0.40 & 39.1 & 2.09 & 1.10 & 0.37 & 52.9 & 0.78 & 0.47 & 0.27 & 8.0 & 0.080 & 0.013 \\
\hline \multicolumn{15}{|c|}{ Canil and O’Neill (1996) refitted } \\
\hline $89-719$ & 2.26 & 0.90 & 0.33 & 47.3 & 2.00 & 0.89 & 0.33 & 51.6 & 0.90 & 0.14 & 0.37 & 1.1 & 0.011 & 0.005 \\
\hline BD1150 & 2.27 & 0.87 & 0.33 & 61.1 & 2.03 & 0.84 & 0.24 & 36.5 & 1.07 & 0.02 & 0.39 & 2.4 & 0.024 & 0.015 \\
\hline BD1140 & 2.52 & 0.91 & 0.26 & 9.1 & 2.12 & 0.90 & 0.29 & 89.1 & 0.96 & 0.01 & 0.32 & 1.8 & 0.018 & 0.007 \\
\hline BD1201 & 2.35 & 0.88 & 0.28 & 12.3 & 2.03 & 0.86 & 0.28 & 86.6 & 0.97 & 0.12 & 0.35 & 1.2 & 0.012 & 0.009 \\
\hline BD1354 & 2.30 & 0.85 & 0.31 & 16.0 & 2.01 & 0.86 & 0.29 & 82.0 & 0.68 & 0.13 & 0.24 & 2.0 & 0.020 & 0.014 \\
\hline PHN5276 & 2.53 & 0.85 & 0.38 & 5.6 & 2.10 & 0.89 & 0.30 & 89.9 & 0.71 & 0.22 & 0.25 & 1.5 & 0.015 & 0.009 \\
\hline FRB 1350 & 2.91 & 0.89 & 0.36 & 12.8 & 2.12 & 0.90 & 0.32 & 85.2 & 0.69 & 0.18 & 0.25 & 2.0 & 0.020 & 0.009 \\
\hline
\end{tabular}


Table 4

Click here to download Table: Table4 GAG.doc

Table 4. Mössbauer hyperfine parameters (mm/s) and $\mathrm{Fe}^{2+}$ and $\mathrm{Fe}^{3+}$ percentages for garnets

\begin{tabular}{|c|c|c|c|c|c|c|c|c|c|c|c|c|}
\hline \multirow{2}{*}{ Sample } & \multicolumn{5}{|c|}{$\mathrm{Fe}^{2+}$ asymm } & \multicolumn{4}{|c|}{$\mathrm{Fe}^{3+}$} & \multirow{2}{*}{$\mathrm{Fe}^{3+} / \Sigma \mathrm{Fe}$} & \multirow{2}{*}{$\begin{array}{l}\mathrm{Fe}^{3+} / \Sigma \mathrm{Fe} \\
\text { corrected* }\end{array}$} & \multirow{2}{*}{ err } \\
\hline & QS & IS & HW1 & HW2 & $\%$ & QS & IS & HW & $\%$ & & & \\
\hline \multicolumn{13}{|c|}{ Udachnaya coarse } \\
\hline U29 & 3.56 & 1.28 & 0.36 & 0.30 & 91.9 & 0.42 & 0.16 & 0.59 & 8.1 & 0.081 & 0.059 & 0.010 \\
\hline U64 & 3.55 & 1.28 & 0.37 & 0.29 & 88.8 & 0.29 & 0.34 & 0.34 & 11.2 & 0.112 & 0.081 & 0.013 \\
\hline U283 & 3.56 & 1.28 & 0.35 & 0.27 & 92.0 & 0.49 & 0.17 & 0.24 & 8.0 & 0.080 & 0.058 & 0.016 \\
\hline U501 & 3.55 & 1.29 & 0.35 & 0.28 & 94.2 & 0.31 & 0.17 & 0.55 & 5.8 & 0.058 & 0.044 & 0.009 \\
\hline \multicolumn{13}{|c|}{ Udachnaya sheared } \\
\hline U10 & 3.55 & 1.28 & 0.36 & 0.29 & 83.0 & 0.30 & 0.32 & 0.40 & 17.1 & 0.171 & 0.127 & 0.013 \\
\hline U70 & 3.55 & 1.28 & 0.36 & 0.30 & 86.4 & 0.29 & 0.33 & 0.35 & 13.6 & 0.136 & 0.101 & 0.013 \\
\hline U183 & 3.55 & 1.29 & 0.37 & 0.29 & 89.5 & 0.33 & 0.34 & 0.30 & 10.5 & 0.105 & 0.077 & 0.009 \\
\hline U267 & 3.55 & 1.29 & 0.36 & 0.30 & 89.6 & 0.27 & 0.34 & 0.35 & 10.4 & 0.104 & 0.076 & 0.012 \\
\hline Y-10 & 3.55 & 1.29 & 0.36 & 0.29 & 89.3 & 0.28 & 0.35 & 0.37 & 10.8 & 0.108 & 0.081 & 0.014 \\
\hline Y-19 & 3.55 & 1.29 & 0.37 & 0.30 & 88.3 & 0.25 & 0.33 & 0.34 & 11.7 & 0.117 & 0.087 & 0.016 \\
\hline $87 / 70$ & 3.55 & 1.28 & 0.37 & 0.32 & 84.0 & 0.30 & 0.37 & 0.42 & 16.0 & 0.160 & 0.119 & 0.013 \\
\hline $87 / 97$ & 3.56 & 1.29 & 0.38 & 0.30 & 89.5 & 0.32 & 0.38 & 0.31 & 10.5 & 0.105 & 0.078 & 0.019 \\
\hline \multicolumn{13}{|c|}{ Dariganga coarse } \\
\hline $8508-6$ & 3.56 & 1.29 & 0.36 & 0.31 & 93.8 & 0.28 & 0.13 & 0.30 & 6.2 & 0.062 & 0.048 & 0.022 \\
\hline $8508-9$ & 3.55 & 1.29 & 0.36 & 0.29 & 95.2 & 0.27 & 0.10 & 0.29 & 4.9 & 0.049 & 0.038 & 0.020 \\
\hline BY-18 & 3.55 & 1.29 & 0.39 & 0.31 & 94.1 & 0.27 & 0.20 & 0.36 & 5.9 & 0.059 & 0.048 & 0.017 \\
\hline BY-19 & 3.55 & 1.29 & 0.37 & 0.29 & 94.9 & 0.31 & 0.12 & 0.31 & 5.1 & 0.051 & 0.042 & 0.011 \\
\hline BY-27 & 3.55 & 1.28 & 0.36 & 0.30 & 94.9 & 0.30 & 0.33 & 0.27 & 5.1 & 0.051 & 0.041 & 0.021 \\
\hline BY-33 & 3.55 & 1.29 & 0.38 & 0.31 & 93.9 & 0.36 & 0.25 & 0.55 & 6.1 & 0.061 & 0.050 & 0.024 \\
\hline \multicolumn{13}{|c|}{ Canil and O’Neill (1996) refitted } \\
\hline $89-719$ & 3.58 & 1.30 & 0.36 & 0.30 & 89.6 & 0.32 & 0.15 & 0.50 & 5.2 & 0.052 & 0.037 & 0.006 \\
\hline BD1150 & 3.57 & 1.29 & 0.33 & 0.28 & 93.7 & 0.36 & 0.29 & 0.47 & 6.3 & 0.063 & 0.045 & 0.005 \\
\hline BD1140 & 3.57 & 1.29 & 0.34 & 0.28 & 95.0 & 0.28 & 0.29 & 0.50 & 5.0 & 0.050 & 0.036 & 0.004 \\
\hline BD1201 & 3.58 & 1.30 & 0.33 & 0.27 & 95.4 & 0.26 & 0.33 & 0.37 & 4.6 & 0.046 & 0.033 & 0.006 \\
\hline BD1354 & 3.58 & 1.30 & 0.32 & 0.28 & 90.4 & 0.30 & 0.32 & 0.37 & 9.6 & 0.096 & 0.069 & 0.004 \\
\hline PHN5276 & 3.56 & 1.04 & 0.34 & 0.28 & 84.9 & 0.34 & 0.08 & 0.44 & 15.2 & 0.152 & 0.109 & 0.010 \\
\hline FRB1350 & 3.57 & 1.29 & 0.33 & 0.28 & 95.3 & 0.43 & 0.13 & 0.42 & 4.7 & 0.047 & 0.034 & 0.004 \\
\hline
\end{tabular}

*: corrected for recoil-free fractions in garnet after Woodland and Ross (1994). 
Table 5

Click here to download Table: Table5_GAG.doc

Table 5. Mössbauer hyperfine parameters $(\mathrm{mm} / \mathrm{s})$ and $\mathrm{Fe}^{2+}$ and $\mathrm{Fe}^{3+}$ percentages for clinopyroxenes

\begin{tabular}{|c|c|c|c|c|c|c|c|c|c|c|c|c|c|c|}
\hline \multirow{2}{*}{ Sample } & \multicolumn{4}{|c|}{$\mathrm{Fe}^{2+} \mathrm{I}$} & \multicolumn{4}{|c|}{$\mathrm{Fe}^{2+} \mathrm{II}$} & \multicolumn{4}{|c|}{$\mathrm{Fe}^{3+}$} & \multirow{2}{*}{$\mathrm{Fe}^{3+} / \Sigma \mathrm{Fe}$} & \multirow{2}{*}{ err } \\
\hline & QS & IS & HW & $\%$ & QS & IS & HW & $\%$ & QS & IS & HW & $\%$ & & \\
\hline \multicolumn{15}{|c|}{ Udachnaya sheared } \\
\hline U267 & 2.33 & 1.30 & 0.30 & 16.6 & 2.02 & 1.16 & 0.39 & 65.8 & 0.54 & 0.36 & 0.57 & 17.6 & 0.176 & 0.035 \\
\hline $87-70$ & 2.33 & 1.14 & 0.44 & 11.1 & 2.06 & 1.19 & 0.44 & 79.6 & 0.50 & 0.37 & 0.68 & 9.3 & 0.093 & 0.021 \\
\hline $87-97$ & 2.02 & 1.19 & 0.45 & 14.2 & 1.87 & 1.20 & 0.49 & 77.2 & 0.58 & 0.32 & 0.52 & 8.6 & 0.086 & 0.014 \\
\hline \multicolumn{15}{|c|}{ Dariganga coarse } \\
\hline $8508-6$ & 2.63 & 1.09 & 0.38 & 7.1 & 2.06 & 1.16 & 0.45 & 70.1 & 0.64 & 0.44 & 0.59 & 22.8 & 0.228 & 0.028 \\
\hline $8508-9$ & 2.58 & 1.13 & 0.31 & 11.5 & 2.04 & 1.15 & 0.44 & 61.0 & 0.63 & 0.44 & 0.65 & 27.5 & 0.275 & 0.064 \\
\hline BY-18 & 2.54 & 1.13 & 0.35 & 15.2 & 2.07 & 1.16 & 0.48 & 62.6 & 0.57 & 0.47 & 0.54 & 22.2 & 0.222 & 0.054 \\
\hline BY-19 & 2.68 & 1.15 & 0.32 & 12.7 & 2.10 & 1.16 & 0.49 & 61.2 & 0.66 & 0.44 & 0.61 & 26.1 & 0.261 & 0.062 \\
\hline BY-27 & 2.61 & 1.13 & 0.31 & 15.0 & 2.05 & 1.16 & 0.44 & 56.7 & 0.66 & 0.41 & 0.60 & 28.4 & 0.284 & 0.045 \\
\hline BY -33 & 2.72 & 1.16 & 0.34 & 14.2 & 2.08 & 1.16 & 0.46 & 64.6 & 0.69 & 0.46 & 0.53 & 21.2 & 0.212 & 0.042 \\
\hline \multicolumn{15}{|c|}{ Canil and O'Neill (1996) refitted } \\
\hline 89-719 & 2.67 & 1.16 & 0.39 & 9.8 & 2.05 & 1.14 & 0.44 & 62.5 & 0.41 & 0.31 & 0.53 & 27.7 & 0.277 & 0.075 \\
\hline BD1150 & 2.61 & 1.15 & 0.42 & 16.2 & 2.03 & 1.15 & 0.44 & 51.8 & 0.48 & 0.41 & 0.59 & 32.0 & 0.320 & 0.065 \\
\hline BD1140 & 2.70 & 1.18 & 0.42 & 8.8 & 2.05 & 1.15 & 0.44 & 58.4 & 0.50 & 0.37 & 0.67 & 32.8 & 0.328 & 0.078 \\
\hline BD1201 & 2.55 & 1.13 & 0.46 & 18.9 & 2.03 & 1.14 & 0.41 & 43.9 & 0.42 & 0.37 & 0.54 & 37.3 & 0.373 & 0.082 \\
\hline BD1354 & 2.44 & 1.19 & 0.51 & 21.8 & 2.03 & 1.15 & 0.40 & 53.7 & 0.51 & 0.39 & 0.47 & 24.5 & 0.245 & 0.022 \\
\hline PHN5276 & 2.08 & 1.14 & 0.36 & 74.0 & 1.82 & 1.10 & 0.22 & 14.7 & 0.51 & 0.30 & 0.48 & 11.3 & 0.113 & 0.013 \\
\hline FRB1350 & 2.66 & 1.12 & 0.47 & 11.7 & 1.99 & 1.16 & 0.42 & 76.5 & 0.74 & 0.39 & 0.44 & 11.8 & 0.118 & 0.037 \\
\hline
\end{tabular}


Table 6. Effect of changing redox conditions on Opx-Grt thermometry for mantle xenoliths equilibrated under 'average' redox conditions.

\begin{tabular}{|c|c|c|c|c|c|c|c|c|}
\hline Sample & $\begin{array}{l}\text { Redox } \\
\text { conditions }\end{array}$ & $\begin{array}{l}\Delta \log f \mathrm{O}_{2} \\
(\mathrm{QFM})^{*}\end{array}$ & $\begin{array}{c}\mathrm{Fe}^{3+} / \mathrm{Fe}_{\text {tot }} \\
\text { Grt } \$\end{array}$ & $\begin{array}{c}\mathrm{Fe}^{3+} / \mathrm{Fe}_{\text {tot }} \\
\text { Opx\# }\end{array}$ & $\begin{array}{l}\text { PNG85 GPa } \\
\text { (at TTA98) }\end{array}$ & $\begin{array}{c}\mathrm{TNG} 10{ }^{\circ} \mathrm{C} \\
(\text { at PNG85) } \dagger\end{array}$ & $\begin{array}{l}\text { PNG85 GPa } \\
(\text { at TNG10) }\end{array}$ & $\begin{array}{c}\mathrm{TNG} 10{ }^{\circ} \mathrm{C} \\
(\text { at PNG85) }\end{array}$ \\
\hline \multirow[t]{3}{*}{ FRB 1350} & original & -0.67 & 0.034 & 0.021 & 2.08 & 724 & 2.47 & 761 \\
\hline & lowest & -2.50 & 0.012 & 0.007 & 2.08 & 729 & 2.42 & 762 \\
\hline & highest & +1.02 & 0.085 & 0.055 & 2.08 & 713 & 2.60 & 763 \\
\hline \multirow[t]{3}{*}{ FRB135 } & original & -1.79 & 0.057 & 0.048 & 3.57 & 961 & 4.03 & 1009 \\
\hline & lowest & -3.42 & 0.023 & 0.019 & 3.57 & 965 & 3.90 & 1000 \\
\hline & highest & +0.21 & 0.162 & 0.140 & 3.57 & 946 & 4.69 & 1062 \\
\hline \multirow[t]{3}{*}{ Bo-08 } & original & -2.27 & 0.071 & 0.053 & 4.59 & 1114 & 5.18 & 1178 \\
\hline & lowest & -4.02 & 0.027 & 0.020 & 4.59 & 1125 & 4.87 & 1156 \\
\hline & highest & -0.30 & 0.194 & 0.149 & 4.59 & 1082 & 7.20 & 1364 \\
\hline \multirow[t]{3}{*}{$22-7$} & original & -2.59 & 0.085 & 0.020 & 5.58 & 1124 & 5.63 & 1129 \\
\hline & lowest & -4.49 & 0.030 & 0.007 & 5.58 & 1162 & 5.87 & 1193 \\
\hline & highest & -0.75 & 0.214 & 0.056 & 5.58 & 1036 & 5.15 & 996 \\
\hline \multirow[t]{3}{*}{ U183 } & original & -3.42 & 0.077 & 0.018 & 6.40 & 1237 & 6.52 & 1250 \\
\hline & lowest & -4.97 & 0.033 & 0.007 & 6.40 & 1270 & 6.67 & 1299 \\
\hline & highest & -1.15 & 0.238 & 0.064 & 6.40 & 1118 & 6.17 & 1096 \\
\hline
\end{tabular}

*: "original" calculated from natural compositions with the oxybarometer of Stagno et al. (2013); "lowest" and "highest" bracket the maximum range for mantle peridotites at respective depth (cf. Fig. 8);

$\S:$ "original" measured on natural samples; "lowest" and "highest" calculated by reversing the oxybarometer of Stagno et al. (2013) at "lowest" and "highest" $\mathrm{fO}_{2}$;

\#: calculated from garnet composition using Equation (6);

$\dagger: T$ (Nimis and Grütter 2010) calculated at $P$ given by combination of Nickel and Green's (1985) barometer (PNG85) and Taylor's (1998) thermometer (TTA98);

f: $T$ (Nimis and Grütter 2010) and $P$ (Nickel and Green 1985) calculated by iteration.

Sources of compositional data: FRB1350 - Pearson et al. (1994) and this work; FRB135 - Luth et al. (1990); Bo-08 Creighton et al. (2009); 22-7 - Kopylova et al. (1999a) and McCammon and Kopylova (2004); U183 - Ionov et al. (2010) and this work. 
$1 \mathrm{Fe}^{3+}$ partitioning systematics between orthopyroxene and garnet in

2 mantle peridotite xenoliths and implications for thermobarometry of

\section{3 oxidized and reduced mantle rocks}

4

Paolo Nimis ${ }^{1, *}$, Aleksey Alexey Goncharov ${ }^{2}$, Dmitri A. Ionov $^{3}$, Catherine McCammon ${ }^{4}$ 6

$7 \quad{ }^{1}$ Dipartimento di Geoscienze, Università di Padova, Italy

8

\section{${ }^{2}$ Faculty of Geology Institute of Earth Sciences, Saint-Petersburg State University \&} $\underline{\text { IPGG RAS, }}$, Saint-Petersburg, Russia

${ }^{3}$ Géosciences Montpellier, CNRS-UMR 5243 - Université Montpellier II, 34095

Montpellier, France

${ }^{4}$ Bayerisches Geoinstitut, Universität Bayreuth, D-95440 Bayreuth, Germany

*: Corresponding author

e-mail: paolo.nimis@unipd.it

tel: $+39-0498279161$

fax: $+39-0498279134$ 
Abstract We have investigated the partitioning of $\mathrm{Fe}^{3+}$ between orthopyroxene (Opx) and garnet (Grt) in well-equilibrated mantle xenoliths using Mössbauer spectroscopy. The samples cover a wide range of $P-T$ conditions $\left(2.1-6.6 \mathrm{GPa}, 690-1,412{ }^{\circ} \mathrm{C}\right)$ and geothermal gradients, and are thus representative for Earth's upper mantle in both oncraton and off-craton continental settings. Garnet has $\mathrm{Fe}^{3+} / \mathrm{Fe}_{\text {tot }}$ ratios of $0.03-0.13$ and $\mathrm{Fe}_{2} \mathrm{O}_{3}$ contents of $0.24-1.00 \mathrm{wt} \%$. Orthopyroxene has, on average, lower $\mathrm{Fe}^{3+} / \mathrm{Fe}_{\text {tot }}$ ratios (0.01-0.09) and $\mathrm{Fe}_{2} \mathrm{O}_{3}$ contents $(0.05-0.63$ wt $\%)$. In low-pressure, high-temperature samples, however, Opx is systematically richer in $\mathrm{Fe}_{2} \mathrm{O}_{3}$ than the coexisting Grt. The $\mathrm{Fe}^{3+} \mathrm{Opx} / \mathrm{Grt}$ partition coefficient $\left(D_{\mathrm{Fe}^{3+}}^{\mathrm{Opx} / \mathrm{Grt}}\right.$ ) shows no obvious relationship with temperature, but increases a negative correlation-with decreasing pressure and a positive eorrelation-with increasing the $-\mathrm{Na}_{2} \Theta^{\mathrm{Opx}}$. The observed $\mathrm{Opx} / \mathrm{Grt} \mathrm{Fe}^{3+}$ systematics imply that the $\mathrm{Opx}-\mathrm{Grt} \mathrm{Fe}-\mathrm{Mg}$ exchange thermometer is not robust against redox changes if total $\mathrm{Fe}$ is treated as $\mathrm{Fe}^{2+}$. An approximate evaluation of errors on $T$ estimates due to redox effects predicts negligible deviations for strongly reduced conditions $\left(<65^{\circ} \mathrm{C}\right)$, but potentially large deviations ( $>$ to $>>100{ }^{\circ} \mathrm{C}$ ) for strongly oxidized conditions, especially at very high pressure and when both $P$ and $T$ are calculated by iteration.

Keywords Ferric iron, Orthopyroxene, Garnet, Mantle xenoliths, Thermobarometry 


\section{Introduction}

Studies of the distribution of ferric iron in mantle minerals have provided important insights into the redox state and geochemical processes in the Earth-Frost and MeCammon 2008). Measured $\mathrm{Fe}^{3+} / \mathrm{Fe}_{\text {tot }}$ ratios in garnet and spinel from xenoliths have been used to derive oxygen fugacity profiles for several upper mantle sections (e.g., Luth et al. 1990; Luth and Canil 1993; Woodland and Peltonen 1999; Woodland and Koch 2003; McCammon and Kopylova 2004; Lazarov et al. 2009; Yaxley et al. 2012; Creighton et al. 2009, 2010; Goncharov and Ionov 2012; Goncharov et al. 2012). These data are of paramount importance for our understanding of processes involving volatilebearing metasomatic fluids and melts active in the lithosphere today and during its evolution, including those involved in diamond formation and Earth's degassing (Woodland and Koch 2003; Shirey et al. 2013; Stagno et al. 2013).

A large number of $\mathrm{Fe}^{3+}$ analyses are now available for garnet, pyroxenes and spinel, which are the most important carriers of $\mathrm{Fe}^{3+}$ in the upper mantle. The contents and distribution of $\mathrm{Fe}^{3+}$ among these minerals are controlled by crystal-chemical constraints and $P-T$ conditions and are affected by partial melting and metasomatism (Frost and McCammon 2008). It was recognized that in sub-cratonic mantle sections garnet $\mathrm{Fe}^{3+} / \mathrm{Fe}_{\text {tot }}$ ratios and garnet/clinopyroxene $\mathrm{Fe}^{3+}$ partition coefficients tend to increase with temperature (Woodland and Koch 2003; Canil and O'Neill 1996; Woodland 2009). In addition, owing to stabilization of the $\mathrm{Fe}^{2+}{ }_{3} \mathrm{Fe}^{3+}{ }_{2} \mathrm{Si}_{3} \mathrm{O}_{12}$ ("skiagite") component in garnet with pressure, oxygen fugacity has been shown to be driven to lower values relative to the FMQ buffer with increasing depth (Gudmundsson and Wood 1995). 
Despite the large amount of data on $\mathrm{Fe}^{3+}$ distribution in mantle rocks, specific information on the partitioning of $\mathrm{Fe}^{3+}$ between orthopyroxene (hereafter Opx) and garnet (hereafter Grt) is still very scarce. Predictive theoretical modeling of this partitioning is hampered by the lack of accurate thermodynamic data for $\mathrm{Fe}^{3+}$-bearing Opx. Empirical modeling is also problematic due to the paucity of analytical data for Opx. To our knowledge, reliable partitioning data for Opx-Grt pairs are restricted to a set of eight mantle xenoliths, which were analyzed by conventional Mössbauer spectroscopy by Canil and O’Neill (1996), and two compositionally zoned Opx-Grt pairs from metasomatized xenoliths, which were analyzed by high-spatial-resolution Mössbauer spectroscopy by McCammon et al. (2001). Two additional pairs were reported for orogenic garnet peridotites by Malaspina et al. (2012), who used complementary analytical techniques for the determination of ferric iron, i.e., flankmethod electron probe micro-analysis (EPMA) for Grt and electron energy-loss spectroscopy for Opx. in Canil and O'Neill's (1996) xenoliths is dependent on equilibrium $P-T$ conditions, implying a significant effect of mantle redox state on Opx-Grt Fe-Mg-exchange thermometry. Unfortunately, the strong correlation between $P$ and $T$ in these samples did not allow discrimination of the net effects of $P$ and $T$ on $\mathrm{Fe}^{3+}$ partitioning. More recently, Matjuschkin et al. (2014) performed experiments in the CFMAS peridotitic system at 5 GPa and $1,100-1,400{ }^{\circ} \mathrm{C}$ under strongly oxidized conditions and measured $\mathrm{Fe}^{3+}$ contents in the garnets with the flank method. These authors observed a marked improvement of Opx-Grt temperature estimates using the Harley (1984) Fe-Mg exchange thermometer 
when the significant $\mathrm{Fe}^{3+}$ contents in the garnets were accounted for and suggested that $\mathrm{Fe}^{3+} / \mathrm{Fe}_{\text {tot }}$ ratios in the coexisting orthopyroxenes should be comparatively small. To gain a better insight into the partitioning systematics of ferric iron between Opx and Grt under conditions relevant to Earth's upper mantle, we have undertaken a Mössbauer study of Opx-Grt pairs in well-equilibrated mantle-xenoliths from both oncraton and off-craton mantle sections, covering a wide $P-T$ field. The results provide new constraints $\underline{\text { indications }}$ on the mechanisms of incorporation of $\mathrm{Fe}^{3+}$ in Opx and have significant implications for mantle thermobarometry. (1)

\section{Materials and methods}

Sample selection, microstructures and compositions

The samples used in the present work were selected among well-studied peridotite xenoliths to cover a range of $P-T$ conditions representative of garnet-facies lithospheric mantle in cratonic and off-craton regions (Table 1). All selected samples show wellequilibrated microstructures. We avoided using samples showing significant alteration or any evidence of chemical disequilibrium, such as significant compositional variations in any minerals, poor consistency between thermometric estimates using independent, mutually-consistent thermometers (cf. Nimis and Grütter 2010) or poor consistency between $f_{\mathrm{O}_{2}}$ estimates using independent, garnet-based and spinel-based oxybarometers (cf. Goncharov and Ionov 2012). 

within the Late Cenozoic Dariganga alkali basaltic field in SE Mongolia (Ionov et al. 1999; Ionov 2002). The peridotites are fertile to moderately refractory garnet lherzolites (2.67-3.9 wt $\% \mathrm{Al}_{2} \mathrm{O}_{3}$ in whole-rocks) containing 53ㄴ-66\% olivine, $1928-267 \%$ Opx, 6$12 \underline{3} \%$ clinopyroxene (hereafter Cpx) and $4-1011 \%$ Grt; one sample (BY-19 $\underline{18}$ ) contains accessory spinel(Table 1). They are coarse- to medium-grained rocks with protogranular textures. The grain size is similar for all silicate minerals. The mineral grains typically have curved boundaries and irregular shapes. Pyroxenes show no optical zoning or unmixing. Garnets have thin kelyphite rims. No volatile-bearing minerals (mica, amphibole, apatite) or silicate glass have been found. Veined peridotites or pyroxenite xenoliths are very uncommon in the whole xenolith suite. The peridotites are fresh and have positive loss on ignition (LOI) values, indicating that the gain of mass due to oxidation of $\mathrm{FeO}$ to $\mathrm{Fe}_{2} \mathrm{O}_{3}$ on heating is greater than the loss of volatiles introduced by alteration.

The selected cratonic peridotites $(\mathrm{N}=12)$ are from the Udachnaya-East kimberlite pipe in the central Siberian craton. The samples are a subset of the xenolith collection described by Doucet et al. (2013, 2014), Goncharov et al. (2012) and Ionov et al. (2010), and were collected in the $420-640 \mathrm{~m}$ depth range in the diamond mine pit from unusually fresh kimberlites. Details on petrographic features, major and trace element compositions of whole-rocks and minerals, and oxygen fugacity estimates can be found in the quoted papers. The rocks range in composition from refracteryCpx-bearing harzburgite to elinepyroxene poør-lherzolite to Opx-bearing wehrlite (Table 1), and show no or little alteration (commonly with positive LOI). Four samples (U29, U64, U283, U501) are coarse (undeformed), seven (U70, U183, U267, Y-10, Y-19, 87/70, 
87/97) are sheared and one (U10) is transitional (incipient deformation with $\leq 10 \%$ of olivine as neoblasts). One of the coarse xenoliths (U283) contains accessory spinel.

Chemical analysis

Major element compositions of minerals used in the present study were determined by wavelength-dispersive spectroscopy electron microprobe analysis at different laboratories. The minerals were analyzed in grain mounts or thin sections. Samples from Dariganga were analyzed at Macquarie University (Sydney) with a Cameca SX-50 instrument at $15 \mathrm{kV}$ voltage and $20 \mathrm{nA}$ current, using natural and synthetic oxide and silicate minerals as standards and the PAP matrix correction. Analyses for U-series samples from Udachnaya are the same as those reported in Ionov et al. (2010) and were obtained at the Laboratoire Magmas et Volcans (Clermont-Ferrand) on a CAMECA SX100 using $15 \mathrm{kV}$ voltage, $15 \mathrm{nA}$ current and counting times of $10-20 \mathrm{~s}$ for peaks and 5$10 \mathrm{~s}$ for background; standards were natural and synthetic minerals; the ZAF correction was applied. The other samples from Udachnaya were analyzed or re-analyzed at Padova IGG-CNR with a CAMECA SX-50 and at Clermont-Ferrand with a CAMECA SX-100 using higher currents $(20 \mathrm{kV}, 40 \mathrm{nA})$ and longer counting times for $\mathrm{Al}, \mathrm{Cr}, \mathrm{Ca}$ and $\mathrm{Na}$ in pyroxenes (40 s peak, $40 \mathrm{~s}$ background) in order to minimize propagation of analytical errors on thermobarometric estimates and optimize the analysis of $\mathrm{Na}$ in Opx. No systematic decrease in measured $\mathrm{Na}$ contents was observed using the higher currents and longer counting times, which excludes significant underestimation due to migration of this element under the electron beam. Analytical standards for pyroxenes and olivine were diopside (for $\mathrm{Si}$ and $\mathrm{Ca}$ ), albite (for $\mathrm{Na}$ ), orthoclase (for $\mathrm{K}$ ) and pure oxides (for 
$\mathrm{Mg}, \mathrm{Al}, \mathrm{Cr}, \mathrm{Fe}, \mathrm{Mn}$ and $\mathrm{Ti})$. For garnet, pyrope was used as a standard for $\mathrm{Mg}$ and $\mathrm{Si}$.

The CAMECA-PAP program was used to convert X-ray counts into weight percent oxides. The analyses are reported in Table $+\underline{2}$.

Mössbauer analysis

Pure Grt, Opx and Cpx grains were handpicked under a microscope from 0.5 to $2.0 \mathrm{~mm}$ size fractions of crushed and sieved rock material. Owing to the small size of some

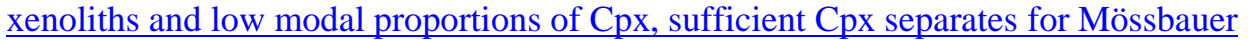
analysis could be obtained only for nine of the investigated samples. The valence state of iron and its structural position in Opx and Grtthe minerals were determined using a SM1201 Mössbauer spectrometer at the IPGG RAS (Saint-Petersburg, Russia) at room temperature in a constant acceleration mode over a velocity range of $\pm 7 \mathrm{~mm} / \mathrm{s}$ with a nominal $50 \mathrm{mCi}{ }^{57} \mathrm{Co}$ source in a $\mathrm{Rh}$ matrix. The spectrometer was calibrated relative to metallic iron at room temperature. Pure Grt and Opx grains were handpicked under a microseope from 0.5 to $2.0 \mathrm{~mm}$ size fractions of crushed and sieved rock material. The minerals were crushed in an agate capsule filled with acetone to avoid iron oxidation in contact with air, pressed in plastic discs and fixed on a special aluminum holder, ensuring an angle between gamma rays and absorber of $54.7^{\circ}$, to avoid asymmetry of the spectra due to preferred orientation of mineral grains. The density of the natural iron in the absorber was about $5 \mathrm{mg} / \mathrm{cm}^{3}$.

The spectra were approximated by a sum of Lorentzian lines using the MOSSFIT $\odot$ software. The relative amounts of $\mathrm{Fe}^{2+}$ and $\mathrm{Fe}^{3+}$ and their site positions in the crystal lattice were determined from integral doublet intensities and hyperfine parameters, 
assuming equal Mössbauer effect probabilities for $\mathrm{Fe}^{2+}$ and $\mathrm{Fe}^{3+}$ at different sites for Opx and different recoil-free fractions of Fe in octahedral and dodecahedral sites for Grt. Constraints on the equality of halfwidths (HW) and integral intensities of the lines in each doublet component of quadrupole splitting (QS) were imposed during spectra fitting. The quality of experimental spectra was assessed by background intensity and the quality of fitting by chi-square distribution.

The fitting model for Grt included a single QS doublet for $\mathrm{Fe}^{2+}$ and $\mathrm{Fe}^{3+}$. The relative peak widths and areas of the $\mathrm{Fe}^{2+}$ doublet, assigned to dodecahedral (distorted cube) site occupancy, were left unconstrained to account for spectra asymmetry (Amthauer et al. 1976). The doublet attributable to octahedrally coordinated $\mathrm{Fe}^{3+}$ was constrained to have components with equal widths and intensities. The $\mathrm{Fe}^{3+} / \mathrm{Fe}_{\text {tot }}$ values obtained were corrected for different recoil-free fractions (Woodland and Ross 1994).

The fitting model for Opx and Cpx included two QS doublets for $\mathrm{Fe}^{2+}$ and one for $\mathrm{Fe}^{3+}$. InAlthough previous studies (e.g. Luth \&and Canil 1993; Canil \&and O’Neill 1996), used three QS doublets for $\mathrm{Fe}^{2+}$ in opx were used-in the fitting procedure, but at $\underline{\text { this approach led to unreasonably small half weightidthsHW-of lines are very low. }}$ Addition of the extra doublet is not statistically justified when the lines overlap by more than their halfwidthHW, where the Adding the third doublet for Fe ${ }^{2+}$ did not alter

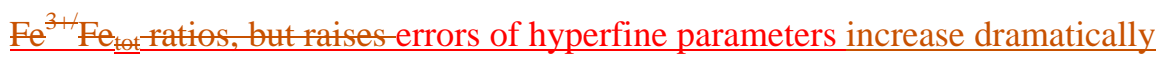
(Goncharov, 2009Dollase, 1975). We also note that adding the extra doublet for $\mathrm{Fe}^{2+} \mathrm{did}$ not alter $\mathrm{Fe}^{3+/} \mathrm{Fe}_{\text {tot }}$ ratios. Therefore, to reach best fitting results, exclude peaks overlap and minimize errors, only two QS doublets for $\mathrm{Fe}^{2+}$ were addedused to fit $\Theta \mathrm{Opx}$ spectra. The QS doublet components, correlated to $\mathrm{Fe}^{2+}$ and $\mathrm{Fe}^{3+}$, assigned to the octahedral site were constrained to have equal widths and intensities. 
The hyperfine parameters and calculated proportions of $\mathrm{Fe}^{2+}$ and $\mathrm{Fe}^{3+}$ at different sites, calculated from HW and integral intensities of lines in QS doublets, are reported in Tables $z \underline{3}$ and to $\underline{35}$. The hyperfine parameters of $\mathrm{Fe}^{3+}$ doublets in Opx are consistent with octahedral coordination (Annersten et al., 1978). No additional lines were observed in any of the spectra, which confirms the absence of other mineral phases, including excluding possible exsolutions of other mineral phases. The absolute errors on the

$\mathrm{Fe}^{3+} / \mathrm{Fe}_{\text {tot }}$ ratios varied from 0.003 to 0.017 for $\mathrm{Opx}_{2}$ and from 0.009 to 0.024 for $\mathrm{Grt}_{2}$ and from 0.01 to 0.06 for Cpx. Two examples of spectra pairs showing different partitioning of $\mathrm{Fe}^{3+}$ between Opx and Grt are shown in Figure 1.

Mössbauer spectra of Opx, Cpx and Grt from mantle xenoliths that had been obtained by conventional Mössbauer spectroscopy by Canil and O’Neill (1996) were reprocessed for this study using the same software and fitting approach used for our samples to ensure robust comparison of the new and old data. Seven setpairs of spectra could be retrieved from the original Canil and O’Neill (1996) files. We obtained similar

Opx spectra we observed that the fitting residuals were larger than the baseline scatter and indicated unequal areas of the main doublet components. This asymmetry is likely caused by a slight preferred orientation of crystallites arising from the nature of the sample mount; therefore the Opx spectra were re-fitted allowing the two $\mathrm{Fe}^{2+}$ doublets to have components with equal HW but unequal intensity according to the fitting approach of McCammon et al. (2000). One of the spectra (sample FRB1350) showed a

contribution from elinopyroxeneolivine, which was estimated to be roughly $8 \underline{13} \%$ of the total area based on the intensity of the high QS impurity. Accordingly, an empirical correction was made to the $\mathrm{Fe}^{3+} / \mathrm{Fe}_{\text {tot }}$ ratio in Opx based on the reported $\mathrm{Fe}^{3+} / \mathrm{Fe}_{\text {tet }}$ value 
of $12 \%$ in the clinopyroxenewell established observation that olivine contains no $\mathrm{Fe}^{3+}$.

234 For the garnets, the same fitting model used for our samples produced $\mathrm{Fe}^{3+} / \mathrm{Fe}_{\text {tot }}$ values

235 within 0.01 of the data reported in Canil and O'Neill (1996), provided the latter were

corrected for different recoil-free fractions. Most of For the clinopyroxenes, the

differences-our refitted $\mathrm{Fe}^{3+} / \mathrm{Fe}_{\text {tot }}$ data for the clinopyroxenes were within 0.02 of thosefrom the $\mathrm{Fe}^{3+} / \mathrm{Fe}_{\text {tot }}$-data reported in Canil and O'Neill (1996), with only two samples at $0.03-0.04$ of the originally reported values were within 0.04 . The results of the refitting are reported in Tables $z \underline{3}$ and 3 to 5 . We emphasize that the change in $\mathrm{Fe}^{3+} / \mathrm{Fe}_{\text {tot }}$ values from our reprocessing of the Canil and O'Neill (1996) data compared to their original values is minor and does not alter any the general conclusions presented in their paper.

\section{Thermobarometry}

The pressures and temperatures of equilibration of the studied xenoliths and of the reprocessed Canil and O’Neill (1996) data (Table 1) were calculated using a combination of the Taylor (1998) two-pyroxene thermometer and Nickel and Green (1985) Opx-Grt barometer recommended by Nimis and Grütter (2010). Given the presence of a few sodium-rich Opx in our data set, we adopted the modified version of the Nickel and Green (1985) barometer proposed by Carswell (1991). This modification was neither expressly favored nor disfavored by Nimis and Grütter (2010), who showed that both versions of the barometer are consistent with constraints imposed by natural xenoliths and experiments in peridotitic systems. Carswell's (1991) version only diverges from the original Nickel and Green (1985) for Opx with $\mathrm{Na}>\mathrm{Cr}+\mathrm{Fe}^{3+}+\mathrm{Ti}$, 
for which it yields somewhat higher pressures (up to 1.2 GPa higher in our data set;

Table 1) and is claimed to be more robust. Owing to the large relative uncertainties in the determination of the small $\mathrm{Fe}^{3+}$ contents in $\mathrm{Opx}, \mathrm{Fe}^{3+}$ was neglected inforin the application of Carswell's (1991) correction.

Only two samples from Udachnaya (U267 and 87/70) showed discrepancies between

Opx-Grt (Nimis and Grütter 2010) and two-pyroxene (Taylor 1998) temperatures slightly larger than the assumed safety threshold of $\pm 70{ }^{\circ} \mathrm{C}$ proposed by Nimis and Grütter (2010), i.e., $+96{ }^{\circ} \mathrm{C}$ and $-77^{\circ} \mathrm{C}$, respectively. Neither of these two samples, however, showed anomalous behavior in terms of $\underline{\mathrm{Opx} / \mathrm{Grt}} \mathrm{Fe}^{3+}$ distribution compared with the other samples.

Three of the samples from the Canil and O'Neill (1996) set for which the Mössbauer spectra were refitted, i.e., BD1140, BD1150 and BD1354, show less than optimal agreement between internally-consistent clinopyroxene-based (Taylor 1998 or Nimis and Taylor 2000) and Opx-based thermometers (Brey and Köhler 1990, with correction in Nimis and Grütter 2010) $\left(\Delta T=100-165^{\circ} \mathrm{C}\right) . P-T$ estimates for these samples should thus be used with caution. Therefore, these three samples will be used for general comparative purposes, but not for quantitative evaluation of $\mathrm{Fe}^{3+}$ systematics.

\section{Results}

The samples studied in this work cover a wide range of estimated $P-T$ conditions (2.16.6 GPa, $690-1,412^{\circ} \mathrm{C}$ ) and geothermal gradients, and are thus representative for Earth's upper mantle in both on-craton and off-craton continental settings (Fig. 2). Garnet has 
$\mathrm{Fe}^{3+} / \mathrm{Fe}_{\text {tot }}$ ratios of $0.03-0.13$ and $\mathrm{Fe}_{2} \mathrm{O}_{3}$ contents of $0.24-1.00 \mathrm{wt} \%$. Orthopyroxene has, on average, lower $\mathrm{Fe}^{3+} / \mathrm{Fe}_{\text {tot }}$ ratios $(0.01-0.09)$ and $\mathrm{Fe}_{2} \mathrm{O}_{3}$ contents $(0.05-0.63$ wt\%). In the low-pressure, high-temperature Dariganga suite, however, Opx is systematically richer in $\mathrm{Fe}_{2} \mathrm{O}_{3}$ than the coexisting Grt (Table 12 ). Such systematic $\mathrm{Fe}^{3+}$-enrichment appears to be unrelated to the abundance of other phases competing for $\mathrm{Fe}^{3+}$, since the modal ranges of $\mathrm{Cpx}(6-13 \mathrm{vol} \%)$ and Grt (3.5-11 vol\%) in Dariganga xenoliths overlap those in the other investigated samples $(\mathrm{Cpx}=1.4-16 \mathrm{vol} \%$; $\mathrm{Grt}=2.1-13 \mathrm{vol} \%)$, and spinel only occurs in minor amounts $(<0.5$ vol\%) in one Dariganga and one Udachnaya $\underline{\text { sample (Table 1). The main reason for the enhanced partitioning of } \mathrm{Fe}^{3+} \text { in Opx must }}$ therefore be found in the specific $P-T$ conditions recorded by the off-craton Dariganga xenoliths and, possibly, in specific compositional controls. The higher $\mathrm{Fe}^{3+}$ contents in Dariganga Opx are coupled with higher ${ }^{[4]} \mathrm{Al}$ contents (Fig. 4a). The latter essentially reflects the low- $P$ and relatively high- $T$ conditions of equilibration of these samples, which are typical of the garnet-facies off-craton lithospheric mantle (Fig. 2). The association of high $\mathrm{Fe}^{3+}$ and high ${ }^{[4]} \mathrm{Al}$ suggests a major role of Tschermaks-type substitution in the incorporation of $\mathrm{Fe}^{3+}$ in Opx. In addition, the three most $\mathrm{Fe}^{3+}$-rich samples in the low- ${ }^{[4]} \mathrm{Al}$ Opx group are those with the highest $\mathrm{Na}$ content, and a similar-correlation of $\mathrm{Fe}^{3+}$ with $\mathrm{Na}$ is also shown by all barof the-ene Dariganga samples except for one, which contains spinel (Fig. 4b). This indicates that an $\underline{\text { additional minor aegirine component } \mathrm{NaFe}^{3+} \mathrm{Si}_{2} \underline{\mathrm{O}}_{6} \text { may also have contributed to the }}$ incorporation of $\mathrm{Fe}^{3+}$ in Opx.

The $\mathrm{Fe}^{3+}$ Opx/Grt partition coefficient $\left(D_{\mathrm{Fe}^{3+}}^{\mathrm{Opx} / \mathrm{Grt}}=\frac{\left(\mathrm{Fe}^{3+}\right)^{\mathrm{Opx}}}{\left(\mathrm{Fe}^{3+}\right)^{\mathrm{Grt}}}\right.$, at. per 4-cation

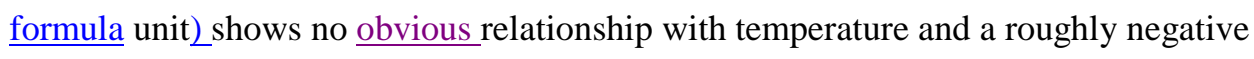


correlation with pressure (Fig. 3a,b). Detailed examination of the relationships between $\underline{\ln } D_{\mathrm{Fe}^{3+}}^{\mathrm{Opx} / \mathrm{Grt}}$ and $P$ showed that the scatter in Figure $3 \mathrm{~b}$ was at least in part correlated with changes in the Na content of Opx. This can beis illustrated by a plot of This partitioning behavior is in contrast with what has been reported for natmral mantle and experimental clinopyroxene garnet pairs, which show enhanced partitioning of $\mathrm{Fe}^{3+}$ to Grt with increasing temperature (Woodland 2009; Purwin et al. 2013). The residuals of the-a $\ln D_{\mathrm{Fe}^{3+}}^{\mathrm{Opx} / \mathrm{Grt}}$ vs. $P \underline{\text { linear regression, which }}$ show a positive correlation with the $\mathrm{Na}_{2} \Theta$ content in Opx (Fig. 3c). Such a correlation is consistent with the inferred contribution of aegirine component to $\mathrm{Fe}^{3+}$ incorporation and suggests an, suggestings a additional second-order-compositional control on the incerperation-partitioning of $\mathrm{Fe}^{3+}$ in-between Opx and Grt. The original data of Canil and O’Neill (1996) are systematically shifted to higher $D_{\mathrm{Fe}^{3+}}^{\mathrm{Opx} / \mathrm{Grt}}$, but the refitted data are in good agreement with our data if the effect of $\mathrm{Na}_{2} \mathrm{O}$ and the uncertainties in $P, D_{\mathrm{Fe}^{3+}}^{\mathrm{Opx} / \mathrm{Grt}}$ is $\underline{\text { and } \mathrm{Na} \text { content }} \underline{\underline{ }} \underline{\mathrm{O}}$ are taken into account (Fig. 3c)

The partitioning behavior observed in our Opx-Grt pairs is in contrast with existing what has been-reportsed for natural mantle and experimental Cpx-Grt pairs: these show enhanced partitioning of $\mathrm{Fe}^{3+}$ to Grt with increasing temperature (Canil and O'Neill 1996; Woodland 2009; Purwin et al. 2013), a tendency which is confirmed also by our dataCpx-Grt pairs (Fig. 5a). A correlation between $\mathrm{Fe}^{3+}$ and $\mathrm{Na}$ in $\mathrm{Cpx}$ is also apparent in our data (Table 2), in line with previous observations in garnet peridotites (Woodland 2009; Malaspina et al. 2012). Owing to the complex combination of $P-T$ and compositional effects, the distribution of $\mathrm{Fe}^{3+}$ between the pyroxenes varies significantly 
among different samples $\left(D_{\mathrm{Fe}^{3+}}^{\mathrm{Opx} / \mathrm{Cpx}}=0.1-0.8\right.$; Fig. 5b). In particular, the high $D_{\mathrm{Fe}^{3+}}^{\mathrm{Opx} / \mathrm{ppx}} \underline{\text { in }}$

Dariganga xenoliths $(0.5-0.7)$ is probably mestly due mostly to a combination of relatively high $T$, low $P$ conditions and moderate $\mathrm{Na}^{\mathrm{Cpx}}$ contents. Quantitative evaluation of $\mathrm{Opx} / \mathrm{Cpx} \mathrm{Fe}^{3+}$ partitioning systematics is beyond the scope of the present work. We only emphasize that estimates of $\mathrm{Opx} \mathrm{Fe}^{3+}$ contents from measured $\mathrm{Fe}^{3+}$ measured in

$\underline{\mathrm{Cpx}}$, based on linear regression of data extracted from limited sets of samples from oncraton mantle settings (cf. Canil and O'Neill 1996), are probably unreliable when applied to Opx-Cpx pairs from different mantle environments.

\section{Discussion}

Because the thermodynamic properties of $\mathrm{Fe}^{3+}$-bearing Opx end-members are unknown, a rigorous thermodynamic treatment of the equilibria involved in the $\mathrm{Fe}^{3+}$ partitioning between Opx and Grt is not possible. However, the topology of the possible relevant reactions and a few approximations allow us to make some qualitative predictions, which may explain the observed partitioning systematics.

Assuming $\mathrm{Fe}^{3+}$ enters into Opx in octahedral coordination, in line with our Mössbauer data, the equilibrium controlling $\mathrm{Fe}^{3+}$ partitioning at constant $f_{\mathrm{O}_{2}}$ can be expressed by an $\mathrm{Fe}^{3+}-\mathrm{Al}$ exchange reaction of the type

$$
1 / 2 M_{3} \mathrm{Fe}^{3+}{ }_{2} \mathrm{Si}_{3} \mathrm{O}_{12}+\mathrm{MgAl}_{2} \mathrm{SiO}_{6} \rightarrow \mathrm{MgFe}^{3+} \mathrm{AlSiO}_{6}+\frac{1}{1} 2 M_{3} \mathrm{Al}_{2} \mathrm{Si}_{3} \mathrm{O}_{12},
$$

Grt Opx Opx Grt


where $\mathrm{M}$ represents a divalent cation (essentially, $\mathrm{Mg}, \mathrm{Fe}^{2+}$ or $\mathrm{Ca}$ ). At equilibrium,

$-\frac{\Delta G^{\circ}}{R T}=\ln K_{\mathrm{Fe}^{3+}-\mathrm{Al}}^{\mathrm{Grt}}=\ln \left(K_{D} \cdot K_{\gamma}\right)=\ln \frac{\left(\mathrm{Fe}^{3+}\right)^{\mathrm{Opx}}}{\left(\mathrm{Fe}^{3+}\right)^{\mathrm{Grt}}}-\ln \frac{\left(\mathrm{Al} \mathrm{M}_{\mathrm{M} 1}\right)^{\mathrm{Opx}}}{(\mathrm{Al})^{\mathrm{Grt}}}+\ln K_{\gamma}$,

where elements are atomic fractions in octahedral sites and $\ln K_{\gamma}$ includes all non-ideal terms. Since reactants and products in reaction (1) are the same and the coordination number of the exchanged cations does not change in the reaction, the volume change of the reaction should be small. Large extrapolation of Domeneghetti et al.'s (1995) data for Pbca orthopyroxenes allows us to predict a molar volume of $\sim 6.1 \mathrm{~J} / \mathrm{bar}$ for the $\mathrm{MgFe}^{3+} \mathrm{AlSiO}_{6}$ end-member. As expected, the calculated $\Delta V^{\circ}$ of reaction (1) is small (ca. net-transfer reaction

$\mathrm{MgAl}_{2} \mathrm{SiO}_{6}+\mathrm{Mg}_{2} \mathrm{Si}_{2} \mathrm{O}_{6} \rightarrow \mathrm{Mg}_{3} \mathrm{Al}_{2} \mathrm{Si}_{3} \mathrm{O}_{12}$

the sum of the other right-hand terms in Equation (2) should also do so in order to maintain the $P$ dependency of $\ln K_{\mathrm{Fe}^{3+}-\mathrm{Al}}^{\mathrm{Grt}}$ small. If the $\ln K_{\gamma}$ term is sufficiently small or does not vary significantly with $P$, then the $\frac{\left(\mathrm{Fe}^{3+}\right)^{\mathrm{Opx}}}{\left(\mathrm{Fe}^{3+}\right)^{\mathrm{Grt}}}$ ratio; $\underline{\text { (i.e., }, \text { and thus }} D_{\mathrm{Fe}^{3+}}^{\mathrm{Opx} / \mathrm{Grt}} ;$, should decrease with increasing pressure. 
$M \mathrm{Fe}^{3+} \mathrm{AlSiO}_{6}+M_{2} \mathrm{Si}_{2} \mathrm{O}_{6} \rightarrow \frac{1}{1 / 2} M_{3} \mathrm{Fe}^{3+}{ }_{2} \mathrm{Si}_{3} \mathrm{O}_{12}+1 / 2 M_{3} \mathrm{Al}_{2} \mathrm{Si}_{3} \mathrm{O}_{12}$.

This net-transfer reaction involves an increase of mean coordination number for both

$M \mathrm{Fe}^{3+}{ }_{2} \mathrm{SiO}_{6}+M_{2} \mathrm{Si}_{2} \mathrm{O}_{6} \rightarrow M_{3} \mathrm{Fe}^{3+}{ }_{2} \mathrm{Si}_{3} \mathrm{O}_{12}$.

divalent and trivalent cations and is therefore expected to be favored by pressure. In fact, a similar equilibrium, with $\mathrm{Cr}$ in lieu of $\mathrm{Fe}^{3+}$, was experimentally calibrated as a geobarometer by Nickel (1989).

If $\mathrm{Fe}^{3+}$ is assumed to enter Opx to $\underline{\text { a minorsome extent also in tetrahedral }}$ coordination (cf. Annersten et al. 1978), then the following net-transfer reaction may become relevant:

$$
\text { Opx Opx Grt }
$$

The topology of this reaction is similar to that of equilibrium (3) (with $\mathrm{Al}$ instead of $\mathrm{Fe}^{3+}$ ), on which the Opx-Grt barometer is based (e.g., Nickel and Green 1985).

Therefore, regardless of the mechanisms of incorporation of $\mathrm{Fe}^{3+}$ in Opx, the $D_{\mathrm{Fe}^{3+}}^{\mathrm{Opx} / \mathrm{Grt}}$ partition coefficient can be predicted to be negatively correlated with pressure, which is in line with our results (Fig. 3).

The positive correlation of the residuals of the $\ln D_{\mathrm{Fe}^{3+}}^{\mathrm{Opx} / \mathrm{Grt}}$ vs. $P$ regression with the $\mathrm{Na}_{2} \mathrm{O}$ content in $\mathrm{Opx}$ (Fig. 3 $\underline{\mathrm{c}}$ ) suggests that $\mathrm{Na}$ also favors incorporation of $\mathrm{Fe}^{3+}$ in $\mathrm{Opx}$, probably as an aemite-aegirine component $\mathrm{NaFe}^{3+} \mathrm{Si}_{2} \mathrm{O}_{6}$. In our data set, no 
compositional variable other than the Na content was found to have a significant refitted Canil and O'Neill's (1996) data yielded the following expression for $D_{\mathrm{Fe}^{3+}}^{\mathrm{Opx}}$ as a function of $P$ and $\mathrm{Na}^{\mathrm{Opx}}{ }_{2} \mathrm{O}$ (Fig. 4):

An alternative expression is

404

409 with eations in-atoms per 64-өxygen-cation (Opx) and 12 oxygen (Grt)-formula units for both Opx and Grt. The good agreement between measured and calculated $\ln D^{\mathrm{Opx} / \mathrm{Grt}}$

(Fig. 6) suggests that most of the observed $D^{\text {Opx/Grt }}$ variability can effectively be explained by the influence of $P$ and $\mathrm{Na}^{\mathrm{Opx}}$ on $\mathrm{Opx} / \mathrm{Grt} \mathrm{Fe}^{3+}$ partitioning. Since the

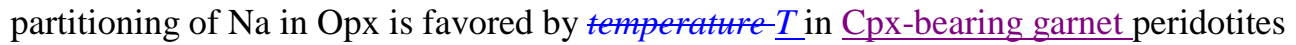


415

416

417

incorporate some minor temperature effect. Attempts to consider explicitly $T$ in the regressions were, however, unsuccessful.

The practical utility of Equations (6) and (7) as a geobarometers is hindered by the relatively small sensitivity of $\ln D_{\mathrm{Fe}^{3+}}^{\mathrm{Opx} / \mathrm{Grt}}$ and $\ln \frac{\left(\mathrm{Fe}^{3+}\right)^{\mathrm{Opx}}}{\left(\mathrm{Fe}^{3+}\right)^{\mathrm{Grt}}}$-to $P$ and by difficult accurate measurement of $\mathrm{Fe}^{3+}$ concentrations in both Opx and $\mathrm{Grt}$ and of $\mathrm{Na}_{2} \mathrm{O}$ in sodium-poor Opx. More interestingly, the equations can be used to estimate $\mathrm{Fe}^{3+}$ contents in orthopyroxenes from mantle peridotites in which only garnets have been analyzed for $\mathrm{Fe}^{3+}$. The $\mathrm{Fe}^{3+}$ systematics expressed by Equations (6) and (7)-may thus be of help in calculations of $\mathrm{Fe}_{2} \mathrm{O}_{3}$ budgets and fluxes during geochemical processes involving mantle rocks. A detailed investigation of these issues is beyond the scope of the present work. We only note that, given its relatively large modal proportion in Grt peridotites and significant affinity for $\mathrm{Fe}^{3+}$, especially at moderate pressure, Opx may represent one of the most important $\mathrm{Fe}^{3+}$ carriers in Earth's upper lithospheric mantle.

Implications for mantle thermobarometry

Opx-Grt Fe-Mg exchange thermometry is based on the equilibrium

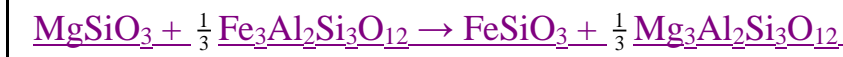
$\underline{O p x}$ Grt Opx Grt

and depends on 
$\ln K_{\mathrm{Fe}^{2+}-\mathrm{Mg}}^{\mathrm{Grt}-\mathrm{Opx}}=\ln \frac{\left(\mathrm{Fe}^{2+}\right)^{\mathrm{Grt}}}{\left(\mathrm{Fe}^{2+}\right)^{\mathrm{Opx}}}+\ln \frac{(\mathrm{Mg})^{\mathrm{Opx}}}{(\mathrm{Mg})^{\mathrm{Grt}}}$ $442=\ln \frac{1-\left(\mathrm{Fe}^{3+} / \mathrm{Fe}_{\mathrm{tot}}\right)^{\mathrm{Opx}}}{1-\left(\mathrm{Fe}^{3+} / \mathrm{Fe}_{\mathrm{tot}}\right)^{\mathrm{Grt}}}$.

443 The difference is null only if the $\frac{1-\left(\mathrm{Fe}^{3+} / \mathrm{Fe}_{\text {tot }}\right)^{\mathrm{Opx}}}{1-\left(\mathrm{Fe}^{3+} / \mathrm{Fe}_{\mathrm{tot}}\right)^{\mathrm{Grt}}}$ ratio (hereafter, 'the iron ratio') is

In common practice, total $\mathrm{Fe}$ is treated as $\mathrm{Fe}^{2+}$, therefore variations in ferric iron contents may affect temperature estimates. Following Nimis and Grütter (2010), the difference between the $\ln K_{D}$ s calculated using total $\mathrm{Fe}$ and $\mathrm{Fe}^{2+}$ is given by

$\ln K_{D \mathrm{Fe}_{\mathrm{tot}}-\mathrm{Mg}}^{\mathrm{Grt}}-\ln K_{D_{\mathrm{Fe}^{2+}-\mathrm{Mg}}^{\mathrm{Grt}-\mathrm{Opx}}}^{\mathrm{G}}=\ln \frac{\left(\mathrm{Fe}_{\mathrm{tot}}\right)^{\mathrm{Grt}}}{\left(\mathrm{Fe}_{\mathrm{tot}}\right)^{\mathrm{Opx}}}-\ln \frac{\left(\mathrm{Fe}^{2+}\right)^{\mathrm{Grt}}}{\left(\mathrm{Fe}^{2+}\right)^{\mathrm{Opx}}}=\ln \frac{\left(\mathrm{Fe}^{2+} / \mathrm{Fe}_{\mathrm{tot}}\right)^{\mathrm{Opx}}}{\left(\mathrm{Fe}^{2+} / \mathrm{Fe}_{\mathrm{tot}}\right)^{\mathrm{Grt}}}=$

equal to unity, i.e., if $\mathrm{Opx}$ and $\mathrm{Grt}$ have the same $\mathrm{Fe}^{3+} / \mathrm{Fe}_{\text {tot }}$ ratio. If this condition is not satisfied, then temperature estimates may be affected by changes in redox conditions, which will affect the $\mathrm{Fe}^{3+} / \mathrm{Fe}_{\text {tot }}$ ratios in both minerals. Therefore, temperature estimates will only be accurate if $\mathrm{Fe}^{3+}$ partitioning and redox conditions in the mantle are comparable to those in the samples used to calibrate the thermometer or if the contributions of ferric iron in the two minerals compensate each other. The latter

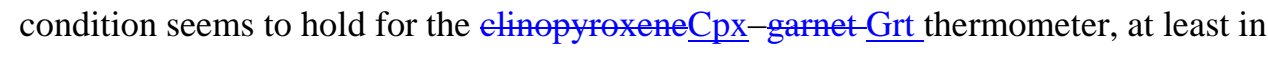
sodium-free systems (Purwin et al. 2013). Based on experimental data at $5 \mathrm{GPa}$, Matjuschkin et al. (2014) suggested that this condition does not apply instead to the Opx-Grt thermometer, owing to strong preferential partitioning of $\mathrm{Fe}^{3+}$ into Grt, but they did not explore the role of pressure. Nimis and Grütter (2010) recalibrated the Opx-Grt thermometer empirically, using well-equilibrated mantle xenoliths as calibrants. They 
found that a correction for pressure was needed, which was larger than expected from thermodynamic treatment of the $\mathrm{Fe}^{2+}-\mathrm{Mg}$ exchange equilibrium, and suggested that this could be due to a systematic increase of the 'iron ratio' with depth. Our results support this hypothesis (Fig. 57).

Using our observed $\mathrm{Fe}^{3+}$ partitioning systematics, we can now explore the effect of changing redox conditions on Opx-Grt thermometry on a quantitative basis. We have estimated potential variations induced on Opx-Grt temperature estimates (Nimis and Grütter 2010; hereafter TNG10) by $f_{2}$ changes within the typical upper mantle range (Fig. 6ㅇ) for a set of xenoliths recording 'average' redox conditions for their respective depths of provenance (see Appendix for details of the calculations). The results (Table 46) show that conditions more oxidized than average, within the typical $\mathrm{fO}_{2}$ range of upper mantle peridotites, will produce negligible (at low $P$ ) to significant (at high $P$ ) $T$ underestimation (over $100{ }^{\circ} \mathrm{C}$ ), whereas conditions more reduced than average will always produce negligible $T$ overestimation $\left(<40^{\circ} \mathrm{C}\right)$.

Nimis and Grütter (2010) suggested that the commonly observed discrepancies between temperature estimates for mantle xenoliths using the Opx-Grt thermometer (TNG10) and the more redox-robust two-pyroxene thermometer of Taylor (1998; hereafter, TTA98), using the same input $P$, could be due either to redox effects (i.e., highly oxidized or highly reduced conditions) or to kinetic decoupling of the fast $\mathrm{Fe}-\mathrm{Mg}$ and slow $\mathrm{Ca}-\mathrm{Mg}$ equilibria due to transient heating. Our results now allow us to refine this premise. Figure 7 9 shows TNG10 - TTA98 discrepancies for a few sets of xenoliths and the maximum potential bias due to redox effects, as derived from data in Table $4 \underline{6}$. It appears that large positive TNG10 - TTA98 discrepancies, such as those shown by some Jagersfontein xenoliths (Fig. 7a 9 a), cannot be ascribed to redox variations and are most 
likely accounted for by short-term thermal perturbations at depth and consequent disequilibrium. Large negative TNG10 - TTA98 discrepancies, such as those shown by some Jagersfontein, Slave or Nikos xenoliths (Fig. 7aa-c) might in part be explained by a high $f \mathrm{O}_{2}$, although disequilibrium or inconsistencies of the TNG10 thermometer for specific $P-T-X$ conditions cannot be excluded.

If $P$ is not kept fixed and both $T$ and $P$ are calculated by iteration according to common practice, the bias on temperature estimates can be considerably amplified. Even so, deviations due to strongly reduced conditions remain small in all cases $\left(\leq-\left(<65^{\circ} \mathrm{C}\right)\right.$ and both positive and negative in sign (Table 46). This is because the increase of Al that is assumed to compensates for the decrease of $\mathrm{Fe}^{3+}$ in Opx (see Appendix) determines a decrease in the $P$ calculated with the Opx-Grt barometer, which in turn tends to counteract the effect of decreasing total $\mathrm{Fe}$ on $T$ estimates, owing to the positive dependency of the Opx-Grt thermometer on $P$. The calculated pressures still remain within only $0.3 \mathrm{GPa}$ of those calculated with the original mineral compositions. Owing to the low $\mathrm{Al}$ in Opx coexisting with $\mathrm{Grt}$, the Al-dependent $P$ estimates may instead be extremely sensitive to the $\mathrm{Al} \rightarrow \mathrm{Fe}^{3+}$ substitution imposed by strongly oxidized conditions. In this case, the corresponding deviations on both $P$ and $T$ estimates become erratic, from strongly negative to strongly positive (Table 46), depending on even modest differences in the original $\mathrm{Al}$ and $\mathrm{Na}$ contents in Opx.

The above exercises contain a significant degree of uncertainty, which derives from uncertainties in the oxybarometer of Stagno et al. (2013), which is used to readjust the $\mathrm{Fe}^{3+} / \mathrm{Fe}_{\text {tot }}$ in the Grt, in the calibration of $\left(\mathrm{Fe}^{3+}\right)^{\mathrm{Opx}} /\left(\mathrm{Fe}^{3+}\right)^{\mathrm{Grt}}$ dependency on $P$ and $\mathrm{Na}_{2} \mathrm{O}^{\mathrm{Opx}}$, in the determination of $\mathrm{Na}_{2} \mathrm{O}^{\mathrm{Opx}}$ in the test samples, and in the mechanisms of 
503

incorporation of $\mathrm{Fe}^{3+}$ in Opx and its effects on the activity of Al-components (see Appendix). Nonetheless, the results cast doubts on the reliability of many existing thermobarometric estimates for elinopyroxeneCpx-free garnet harzburgites and Grt-Opx inclusions in diamonds, for which no independent, sufficiently accurate control on $T$ and $P$ estimates is generally possible (Nimis and Grütter 2010). It is noteworthy that any inconsistency in published $T$ estimates for elinepyroxeneCpx-free xenoliths based on Opx-Grt thermobarometry will be difficult to recognize, because the $T$-dependency of the Opx-Grt barometer will force the $P-T$ points to move roughly along the same conductive geotherm on which the 'good' $P-T$ points will fall (Brey and Köhler 1990).

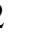

\section{Conclusions}

The partitioning of $\mathrm{Fe}^{3+}$ between orthopyroxene and garnet in our set of mantle xenoliths shows no obvious relationship with temperature, but a-significantppears to vary with dependency on pressure and en the $\mathrm{Na}_{2} \mathrm{O}$ content of the orthopyroxene. This result is unlike previous observations for clinopyroxene-garnet pairs (cf. Woodland 2009;

Purwin et al. 2013). As a consequence, the proportion of $\mathrm{Fe}^{3+}$ over total $\mathrm{Fe}$ in garnetbuffered mantle orthopyroxene is not uniformly low, as commonly assumed, but varies from $1 \%$ (in some high- $P$ and low-Na orthopyroxenes) to at least $9 \%$ (in some low- $P$, relatively high-Na orthopyroxenes equilibrated with garnet). Some low- $P$, high-Na (high-T) mantle orthopyroxenes contain more $\mathrm{Fe}_{2} \mathrm{O}_{3}$ than coexisting garnets.

$\underline{\text { In common practice, redox conditions for garnet peridotites are estimated assuming }}$ $\underline{\text { that } \mathrm{Fe}^{3+} \text { in Opx is negligible, so that } \mathrm{fO}_{2}} \underline{\text { and activity of ferrosilite in Opx can simply be }}$ 
calculated using total Fe concentrations (Gudmundsson and Wood 1995; Stagno et al. 2013). Recalculating ferrsosilite activities in our samples using only $\mathrm{Fe}^{2+}$ instead of $\mathrm{Fe}_{\text {tot }}$, produces a decrease in the calculated $\mathrm{fO}_{2}$ of only $0.02 \log$ units. Therefore, although higher than commonly assumed, the observed $\mathrm{Fe}^{3+} / \mathrm{Fe}_{\text {tot }}$ ratios of up to 9\% in Opx should not affect $\mathrm{fO}_{2}$ estimates based on currently available oxybarometers.

The $\mathrm{Fe}^{3+}$ systematics observed in the studied xenoliths instead imply that the Opx$\mathrm{Grt} \mathrm{Fe}-\mathrm{Mg}$ exchange thermometer is not robust against redox changes if total $\mathrm{Fe}$ is treated as $\mathrm{Fe}^{2+}$. In particular, variations in $\mathrm{Fe}^{3+}$ partitioning with pressure in mantle peridotites may account for some systematic discrepancies observed between experimentally calibrated Opx-Grt and two-pyroxene thermometers (cf. Nimis and Grütter 2010). An approximate evaluation of errors on Opx-Grt temperatures due to redox effects predicts negligible deviations of $P-T$ estimates for strongly reduced conditions, but potentially large deviations for strongly oxidized conditions, especially at very high pressure and when both $P$ and $T$ are calculated by iteration. Therefore, comparisons between $P-T$ estimates derived using Opx-Grt and two-pyroxene thermometers, a common necessity when studying, for instance, both clinopyroxenebearing and clinopyroxene-free peridotites, may be problematic if redox conditions are unknown. An experimental verification of $\mathrm{Fe}^{3+}$ partitioning systematics, e.g., by highresolution Mössbauer analysis of Opx-Grt pairs re-equilibrated under controlled $P-T-$ $\mathrm{fO}_{2}$ and with varying $\mathrm{Na}_{2} \mathrm{O}$ contents, would be desirable to derive a more robust evaluation and, hopefully, recalibration of Opx-Grt thermometers for mantle peridotites.

Acknowledgments We are grateful to Dante Canil for providing access to his original dataset. Sula Milani is thanked for her help in retrieving the old Mössbauer files. Formal 

reviews by Bob Luth and two anonymous referees helped us to improve the paper. PN acknowledges financial support by MIUR ex60\%. DAI thanks Igor Ashchepkov for

553 providing some of the xenoliths used in this study and acknowledges financial support

554 from the French $\mathrm{CNRS}_{2}$ including PNP-INSU and PICS grants, and from the Australian 555

Research Council including Research fellowship and grants in 1994-1998. 556 
Appendix

560

Estimation of maximum bias on Opx-Grt temperature estimates due to changing redox

conditions

Figure $6 \underline{8}$ shows a compilation of existing $f \mathrm{O}_{2}$ data for mantle xenoliths worldwide, recalculated using input $P-T$ values obtained with the thermobarometer combinations recommended by Nimis and Grütter (2010). This choice significantly reduced the scatter of points (especially for Diavik) compared to earlier published versions of this plot (e.g.,

Stagno et al. 2013). Correction of Canil and O'Neill's (1996) Mössbauer data for

different recoil-free fractions in Grt (Table 4) produced a slight decrease in calculated depth.

localities worldwide and should therefore be robust when applied to mantle rocks $\mathrm{fO}_{2}$ of about $0.6 \Delta \log$ units. The plot shows the well-known overall decrease of FMQnormalized oxygen fugacity with increasing mantle depth and a range for $\mathrm{fO}_{2}$ at each From this compilation, we selected five xenoliths coming from different depths and recording 'average' redox conditions for their particular depths of provenance (Table $4 \underline{6}$; Fig. 68 $)$. We calculated the Opx-Grt temperatures for these xenoliths with the thermometer version of Nimis and Grütter (2010) (hereafter TNG10) at $P$ given by the thermobarometers combination recommended by the same authors, using total Fe. The TNG10 thermometer was calibrated against a large set of mantle xenoliths from characterized by 'average' redox conditions. Moreover, aAll selected xenoliths showed very good agreement $\left(\Delta T<60^{\circ} \mathrm{C}\right)$ between thermometric estimates using the internally consistent thermometers recommended by Nimis and Grütter (2010), , which-This 
indicates good equilibrium and also confirms that redox conditions in the xenoliths were indeed 'average' and compatible with the TNG10 thermometer calibration (cf. Nimis and Grütter 2010),; therefore-Therefore the calculated $P-T$ conditions should be reliable.

We then allowed $f_{\mathrm{O}_{2}}$ for each of the selected xenoliths to vary to the maximum and minimum values expected for the mantle at the corresponding depths, as indicated by our compilation in Figure $6 \underline{8}$. We estimated the $\mathrm{Fe}^{3+} / \mathrm{Fe}_{\text {tot }}$ ratios in the garnets at these maximum and minimum redox conditions by reversing the oxybarometer of Stagno et al. (2013), and those in the coexisting orthopyroxenes by using the $\mathrm{Fe}^{3+}$ partitioning systematics obtained in our work (cf. Equation $7 \underline{6}$ ). The mineral compositions were modified using the new $\mathrm{Fe}^{3+} / \mathrm{Fe}_{\text {tot }}$ ratios while keeping $K_{D_{\mathrm{Fe}^{2+}-\mathrm{Mg}}}^{\mathrm{Grt} \text {-Opx }}$ unvaried-the latter depends essentially on $T$, therefore keeping it fixed corresponds to keeping $T$ fixed. An increase (or decrease) in the $\mathrm{Fe}^{3+} / \mathrm{Fe}_{\text {tot }}$ ratio thus determined a net increase (or decrease) in the total $\mathrm{Fe}$ content (actually $\mathrm{Fe}^{3+}$ ), which was compensated by varying the $\mathrm{Al}^{3+}+\mathrm{Cr}^{3+}$ contents by the same magnitude at constant $\mathrm{Al} / \mathrm{Cr}$ ratio. Since the solid solution model for garnet which is used in the oxybarometer of Stagno et al. (2013) is sensitive to the $\mathrm{Al}$ and $\mathrm{Cr}$ contents in the garnet, the $\mathrm{Fe}^{3+} / \mathrm{Fe}_{\text {tot }}$ ratios had to be readjusted by iteration, although the effect of this correction was found to be minimal.

We then recalculated the TNG10 temperatures using the modified total Fe contents in both orthopyroxenes and garnets, either keeping $P$ fixed or recalculating both $P$ and $T$ iteratively. The $P-T$ estimates obtained for the selected xenoliths using the original mineral compositions and the compositions modified for their respective maximum and minimum redox conditions are reported in Table $4 \underline{6}$. We emphasize that , since the aim of this exercise wais to assess 'relative' variations on final $P-T$ estimates, and that 


\section{References}

Annersten H, Olesch M, Seifert FA (1978) Ferric iron in orthopyroxene: a Mössbauer spectroscopic study. Lithos 11:301-310

Ballhaus C (1995) Is the upper mantle metal-saturated? Earth Planet Sci Lett 132:75-86

Boyd FR, Mertzman SA (1987) Composition and structure of the Kaapvaal lithosphere, southern Africa. In: Mysen BO (ed.) Magmatic Processes: Physiochemical Principles. Geochem Soc Spec Publ 1:13-24

Brey GP, Köhler T (1990) Geothermobarometry in four-phase lherzolites II. New thermobarometers, and practical assessment of existing thermobarometers. J Petrol 31:13531378

Canil D, O'Neill HStC (1996) Distribution of ferric iron in some upper-mantle assemblages. J Petrol 37:609-635

Caro G (2000) Petrography of the Kennedy Lake orangeite and its mantle xenoliths. Unpubl MSc thesis, University of British Columbia, $100 \mathrm{p}$

Carswell DA (1991) The garnet-orthopyroxene Al barometer: problematic application to natural garnet lherzolite assemblages. Mineral Mag 55:19-31

Cox KG, Smith MR, Beswetherick S (1987) Textural studies of garnet lherzolites: evidence of exsolution origin from high-temperature harzburgites. In: Nixon PH (ed.) Mantle Xenoliths. John Wiley \& Sons, pp 537-550

Creighton S, Stachel T, Matveev S, Höfer HE, McCammon C, Luth RW (2009) Oxidation of the Kaapvaal lithospheric mantle driven by metasomatism. Contrib Mineral Petrol 157:491-504

Creighton S, Stachel T, Eichenberg D, Luth RW (2010) Oxidation state of the lithospheric mantle beneath Diavik diamond mine, central Slave craton, NWT, Canada. Contrib Mineral Petrol 159:645-657

Dollase WA (1975) Statistical limitations of Mössbauer spectral fitting. Am Miner 60: 257-264

Domeneghetti MC, Molin GM, Tazzoli V (1995) A crystal-chemical model for PBCA orthopyroxene. Am Mineral 80:253-267

Doucet LS, Ionov DA, Golovin AV (2013) The origin of coarse garnet peridotites in cratonic lithosphere: new data on xenoliths from the Udachnaya kimberlite, central Siberia. Contrib Mineral Petrol 165:1225-1242

Doucet LS, Peslier AH, Ionov DA, Brandon AD, Golovin AV, Goncharov AG, Ashchepkov IV (2014) High water contents in the Siberian cratonic mantle linked to metasomatism: an FTIR study of Udachnaya peridotite xenoliths. Geochim Cosmochim Acta 137:159-187 
Frost DJ, McCammon CA (2008) The redox state of Earth's mantle. Annu Rev Earth Planet Sci 36:389-420

Goncharov AG, Ionov DA (2012) Redox state of deep off-craton lithospheric mantle: new data from garnet and spinel peridotites from Vitim, southern Siberia. Contrib Mineral Petrol 164:731-745

Goncharov AG, Ionov DA, Doucet LS, Pokhilenko LN (2012) Thermal state, oxygen fugacity and $\mathrm{C}-\mathrm{O}-\mathrm{H}$ fluid speciation in cratonic lithospheric mantle: New data on peridotite xenoliths from the Udachnaya kimberlite, Siberia. Earth Planet Sci Lett 357-358:99-110

Gregoire M, Bell DR, le Roux AP (2003) Garnet lherzolites from the Kaapvaal craton (South Africa): Trace element evidence for a metasomatic history. J Petrol 44:629-657

Gudmundsson G, Wood BJ (1995) Experimental tests of garnet peridotite oxygen barometry. Contrib Mineral Petrol 119:56-67

Harley SL (1984) An experimental study of the partitioning of Fe and Mg between garnet and orthopyroxene. Contrib. Mineral Petrol 86:359-373

Hops JJ, Gurney JJ, Harte B, Winterburn P (1989) Megacrysts and high temperature nodules from the Jagersfontein kimberlite pipe. In: Ross j (ed) Kimberlites and related rocks, vol 2, Their mantle/crust setting, diamonds and diamond exploration. Geol Soc Aus Spec Publ, vol 14, pp 759-770

Ionov DA (2002) Mantle structure and rifting processes in the Baikal-Mongolia region: geophysical data and evidence from xenoliths in volcanic rocks. Tectonophysics 351:41-60 Ionov DA, Griffin WL, O’Reilly SY (1999) Off-cratonic garnet and spinel peridotite xenoliths from Dsun-Bussular, SE Mongolia. In: Gurney JJ, Gurney JL, Pascoe MD, Richardson SH (eds) Proc 7th Int. Kimb Conf, vol 1. RedRoof Design Cape Town, pp 383-390

Ionov DA, Doucet LS, Ashchepkov IV (2010) Composition of the lithospheric mantle in the Siberian craton: New constraints from fresh peridotites in the Udachnaya-East kimberlite. J Petrol 51:2177-2210

Kopylova MG, Caro G (2004) Mantle xenoliths from the southeastern Slave craton: evidence for chemical zonation in a thick, cold lithosphere. J Petrol 45:1045-1067

Kopylova MG, Russel JK, Cookenboo H (1999a) Petrology of peridotite and pyroxenite xenoliths from the Jericho kimberlite: Implications for the thermal state of the mantle beneath the Slave craton, Northern Canada. J Petrol 40:79-104

Kopylova MG, Russel JK, Cookenboo H (1999b) Mapping the lithosphere below the north central Slave craton. In: Gurney JJ, Gurney JL, Pascoe MD, Richardson SH (eds), J. B. Dawson Volume, Proc 7th Int Kimb Conf, Red Roof Design Cape Town, pp 468-479 
Lazarov M, Woodland AB, Brey GP (2009) Thermal state and redox conditions of the Kaapvaal mantle: A study of xenoliths from the Finsch mine, South Africa. Lithos 112S:913-923

Luth RW, Canil D (1993) Ferric iron in mantle-derived pyroxenes and a new oxybarometer for the mantle. Contrib Mineral Petrol, 113:236-248

Luth RW, Virgo D, Boyd FR, Wood BJ (1990) Ferric iron in mantle-derived garnets.

Implications for thermobarometry and for the oxidation state of the mantle. Contrib Mineral Petrol 104:56-72

Malaspina N, Langenhorst F, Fumagalli P, Tumiati S, Poli S (2012) $\mathrm{Fe}^{3+}$ distribution between garnet and pyroxenes in mantle wedge carbonate-bearing garnet peridotites (Sulu, China) and implications for their oxidation state. Lithos 146-147:11-17

Matjuschkin V, Brey GP, Höfer HE, Woodland AB (2014) The influence of $\mathrm{Fe}^{3+}$ on garnetorthopyroxene and garnet-olivine geothermometers. Contrib Mineral Petrol 167:1-10

McCammon C, Kopylova MG (2004) A redox profile of the Slave mantle and oxygen fugacity control in the cratonic mantle. Contrib Mineral Petrol 148:55-68

McCammon CA, Tennant WC, Miletich RM (2000) A new method for single crystal measurements: Application to studies of mineral inclusions in diamonds. Hyper Inter 126: $241-245$

McCammon CA, Griffin WL, Shee SR, O'Neill HStC (2001) Oxidation during metasomatism in ultramafic xenoliths from the Wesselton kimberlite, South Africa: implications for the survival of diamond. Contrib Mineral Petrol 141:287-296

Nickel KG (1989) Garnet-pyroxene equilibria in the system SMACCR $\left(\mathrm{SiO}_{2}-\mathrm{MgO}-\mathrm{Al}_{2} \mathrm{O}_{3}-\mathrm{CaO}-\right.$ $\mathrm{Cr}_{2} \mathrm{O}_{3}$ ): the Cr-geobarometer. In Ross $\mathrm{J}$ (ed) Kimberlites and related rocks, vol 2, Their mantle/crust setting, diamonds and diamond exploration. Proc 4th Int Kimb Conf, Geol Soc Aus Spec Publ, vol 14, pp 901-912

Nickel KG, Green DH (1985) Empirical geothermobarometry for garnet peridotites and implications for the nature of the lithosphere, kimberlites and diamonds. Earth Planet Sci Lett 73:158-170

Nimis P, Grütter H (2010) Internally consistent geothermometers for garnet peridotites and pyroxenites. Contrib Mineral Petrol 159:411-427

Nimis P, Taylor WR (2000) Single-clinopyroxene thermobarometry for garnet peridotites. Part I. Calibration and testing of a Cr-in-Cpx barometer and an enstatite-in-Cpx thermometer. Contrib Mineral Petrol 139:541-554 
O’Neill HStC, Wall VJ (1987) The olivine-orthopyroxene-spinel oxygen geobarometer, the nickel precipitation curve, and the oxygen fugacity of the earth's upper mantle. J Petrol 28:1169-1191

Pearson DG, Boyd FR, Haggerty SE, Pasteris JD, Field SW, Nixon PH, Pokhilenko NP (1994) The characterisation and origin of graphite in cratonic lithospheric mantle: a petrological carbon isotope and Raman spectroscopic study. Contrib Mineral Petrol 115:449-466

Pollack HN, Chapman DS (1977) On the regional variations of heat flow, geotherms and lithospheric thickness. Tectonophysics 38:279-296

Purwin H, Lauterbach S, Brey GP, Woodland AB, Kleebe H-J (2013) An experimental study of the Fe oxidation states in garnet and clinopyroxene as a function of temperature in the system $\mathrm{CaO}-\mathrm{FeO}-\mathrm{Fe}_{2} \mathrm{O}_{3}-\mathrm{MgO}-\mathrm{Al}_{2} \mathrm{O}_{3}-\mathrm{SiO}_{2}$ : implications for garnet-clinopyroxene geothermometry. Contrib Mineral Petrol 165:623-639

Saltzer RL, Chatterjee N, Grove TL (2001) The spatial distribution of garnets and pyroxenes in mantle peridotites: Pressure-temperature history of peridotites from the Kaapvaal craton. J Petrol 42:2215-2229

Schmidberger SS, Francis D (1999) Nature of mantle roots beneath the North American craton: mantle xenolith evidence from Somerset Island kimberlites. Lithos 48:195-216

Shirey SB, Cartigny P, Frost DJ, Keshav S, Nestola F, Nimis P, Pearson DG, Sobolev NV, Walter MJ (2013) Diamonds and the Geology of Mantle Carbon. Rev Mineral Geochem 75:355-421

Smith D (1999) Temperatures and pressures of mineral equilibration in peridotite xenoliths: Review, discussion, and implications. In: Fei Y, Bertka CM, Mysen BO (eds) Mantle Petrology: Field Observations and high pressure experimentation: A tribute to Francis R. (Joe) Boyd. Geochem Soc Spec Publ, vol 6, pp 171-188

Stagno V, Ojwang DO, McCammon CA, Frost DJ (2013) The oxidation state of the mantle and the extraction of carbon from Earth's interior. Nature 493:84-88

Taylor WR (1998) An experimental test of some geothermometer and geobarometer formulations for upper mantle peridotites with application to the thermobarometry of fertile lherzolite and garnet websterite. Neues Jb Miner Abh 172:381-408

Woodland AB (2009) Ferric iron contents of clinopyroxene from cratonic mantle and partitioning behaviour with garnet. Lithos 112S:1143-1149

Woodland AB, Koch M (2003) Variation in oxygen fugacity with depth in the upper mantle beneath the Kaapvaal craton, Southern Africa. Earth Planet Sci Lett 214:295-310 
Woodland AB, Peltonen P (1999) Ferric iron contents of garnet and clinopyroxene and estimated oxygen fugacities of peridotite xenoliths from the Eastern Finland Kimberlite Province. In JJ Gurney, JL Gurney, MD Pascoe, SH Richardson (eds) Proc 7th Int Kimb Conf, pp 904-911. Red Roof Design Cape Town South Africa

Woodland AB, Ross CR (1994) A crystallographic and Mössbauer spectroscopy study of $\mathrm{Fe}_{3} \mathrm{Al}_{2} \mathrm{Si}_{3} \mathrm{O}_{12}-\mathrm{Fe}_{3}^{2+} \mathrm{Fe}_{2}^{3+} \mathrm{Si}_{3} \mathrm{O}_{12}$ (almandine-skiagite) and $\mathrm{Ca}_{3} \mathrm{Fe}_{2}^{3+} \mathrm{Si}_{3} \mathrm{O}_{12}-\mathrm{Fe}_{3}^{2+} \mathrm{Fe}_{2}^{3+} \mathrm{Si}_{3} \mathrm{O}_{12}$ (andradite-skiagite) garnet solid solutions. Phys Chem Minerals 21:117-132

Yaxley GM, Berry AJ, Kamenetsky VS, Woodland AB, Golovin AV (2012) An oxygen fugacity profile through the Siberian Craton - Fe K-edge XANES determinations of $\mathrm{Fe}^{3+} / \Sigma \mathrm{Fe}$ in garnets in peridotite xenoliths from the Udachnaya East kimberlite. Lithos 140-141:142-151 


\section{Figure Captions}

Fig. 1 Mössbauer spectra for orthopyroxene and garnet in two xenoliths showing different partitioning of $\mathrm{Fe}^{3+}$.

Fig. $2 P-T$ estimates for mantle xenoliths studied in this work. Reference geotherms after Pollack and Chapman (1977). CO'N96 $P-T$ values recalculated using compositional data in Canil and O'Neill (1996) and references therein. The fields of typical on-craton and off-craton garnet peridotites are shown for comparison.

Fig. $3 \mathrm{Opx}-\mathrm{Grt} \mathrm{Fe}^{3+}$ partitioning systematics in mantle xenoliths. Arrows indicate the effect of a eorrection for the presence of ca. 8\% clinopyroxene in the Opx separate of sample FRB 1350 of Canil and O'Neill (1996).Error bars for $\ln D \mathrm{Fe}^{3+}$ and $\mathrm{Na}_{2} \mathrm{O}$ are at $1 \sigma$. Uncertainties on $\mathrm{Na}_{2} \mathrm{O}$ were not reported for the literature samples and were calculated as $0.026-0.08 \cdot \mathrm{Na}_{2} \mathrm{O}$ (wt $\%$ ), based on systematic relationships in our analyses using routine analytical conditions. Error bars for $P$ and $T$ were fixed to $0.4 \mathrm{GPa}, 50{ }^{\circ} \mathrm{C}$, and raised to $0.5 \mathrm{GPa}, 70{ }^{\circ} \mathrm{C}$ for samples equilibrated at $T<800{ }^{\circ} \mathrm{C}$ and for some samples showing poor agreement between internally consistent thermometers (cf. Nimis and Grütter 2010). Dashed lines indicate unweighted linear regressions through the data.

Fig. $4 \mathrm{Fe}^{3+}$ contents vs. tetrahedral $\mathrm{Al}(\mathbf{a})$ and $\mathrm{Na}$ contents $(\mathbf{b})$ in the investigated Opx. The low- ${ }^{[4]} \mathrm{Al}$ group corresponds to the on-craton xenoliths, the high ${ }^{[4]} \mathrm{Al}$ group consists of the off-craton Dariganga xenoliths. The dashed line in b separates the two groups. Spinel-bearing sample BY-18 falls off the trend shown by the other Dariganga samples.

Fig. 5 a Variation of Grt/Cpx $\ln D \mathrm{Fe}^{3+}$ with reciprocal $T$ in the investigated xenoliths. Shaded field: data for garnet peridotites after Woodland and Peltonen (1999), Woodland (2009), Lazarov et al. (2009), plus additional data from Canil and O'Neill (1996). As already pointed out by Canil and O'Neill (1996), the spinel-bearing, very low- $T$ sample FRB1350 falls off the main trend. b Fe ${ }^{3+}$ distribution between Opx and Cpx.

Fig. 4-6 Calculated (Equation 6) vs. measured $\mathrm{Fe}^{3+}$ partitioning between Opx and Grt. Data for Canil and O'Neill's (1996) samples that showed poor agreement between independent thermometric estimates were not considered in the regression. Error bars are at $1 \sigma$. Same symbols as in Fig. 2.

Fig. 5-7 Variation in the Grt-Opx 'iron ratio' with $T$ and $P$ in mantle xenoliths. The relationship with $P$ mimics that shown by $D F^{3+}$ (cf. Fig. $3 \underline{b}$ ). Same symbols as in Fig. 2.

Fig. 6-8 Estimated $\mathrm{fO}_{2}$ normalized to the FMQ buffer (Stagno et al. 2013) for garnet peridotite xenoliths worldwide. The EMOG/D curve corresponds to the enstatite-magnesitegraphite/diamond buffer along a cratonic geotherm (Stagno et al. 2013). The Fe-Ni precipitation curve after O'Neill and Wall (1987). Shaded field approximately indicates the diamond stability field. Dashed lines indicate the apparent typical $\mathrm{fO}_{2}$ range at various mantle depths. Arrows connect five selected well-equilibrated samples recording 'average' $f \mathrm{O}_{2}$ for their respective depth to corresponding maximum and minimum $\mathrm{fO}_{2}$ values. Sources of compositional data: Siberia - Yaxley et al. (2012), Goncharov et al. (2012); Kaapvaal - Luth et al. (1990), Lazarov et al. (2009), Creighton et al. (2009), Canil and O'Neill (1996, as revisited in this work); N and SE Slave McCammon and Kopylova (2004); Diavik - Creighton et al. (2010); Mongolia - this work. 
Seventeen data showing poor agreement $\left(>100^{\circ} \mathrm{C}\right)$ between independent, internally consistent pyroxene thermometers (cf. Nimis and Grütter 2010) were excluded.

Fig. 7-9 Differences between temperatures calculated with the Opx-Grt thermometer (Nimis and Grütter 2010; TNG10) and the two-pyroxene thermometer (Taylor 1998; TTA98) for mantle xenoliths from different localities. All xenoliths show good equilibrium between pyroxenes based on criteria in Nimis and Grütter (2010). Shaded fields indicate the declared uncertainty (2 standard errors of estimate, $\pm 70{ }^{\circ} \mathrm{C}$ ) of the TNG10 thermometer. Dashed lines indicate the maximum predicted bias on TNG10 for strongly reducing and, respectively, strongly oxidized conditions.

Several xenoliths from Jagersfontein show positive deviations well beyond estimated uncertainties, suggesting disequilibrium due to transient heating. Xenolith data from Nimis and Grütter's (2010) compilation, specifically: Jagersfontein - Boyd (pers. comm. to H. Grütter), Cox et al. (1987), Boyd and Mertzman (1987), Hops et al. (1989), Mofokeng (1998), Smith (1999), Saltzer et al. (2001), Grégoire et al. (2003); Slave - Kopylova et al. (1999a,b), Caro (2000), McCammon and Kopylova (2004), Kopylova and Caro (2004); Nikos - Schmidberger and Francis (1999). 